


\section{a d}

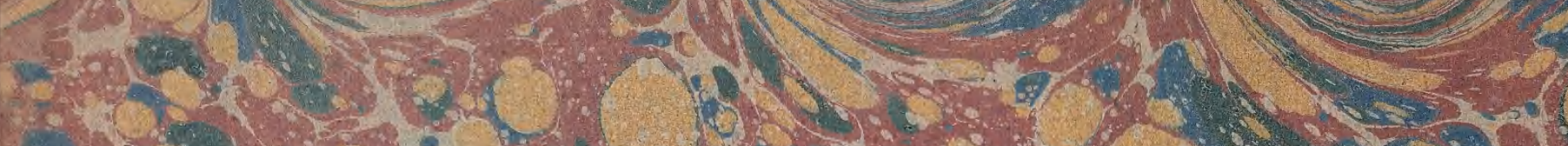

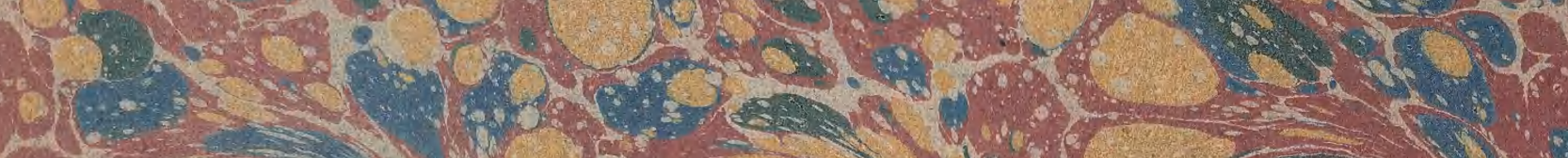

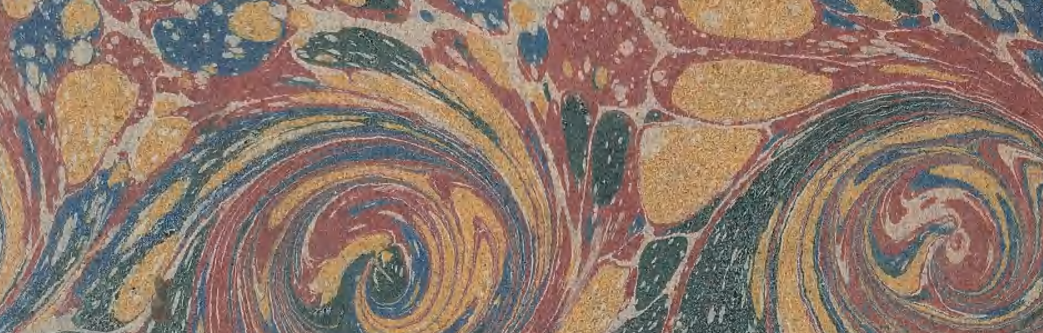

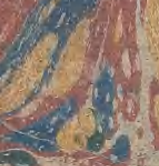

(c)

(1)

.

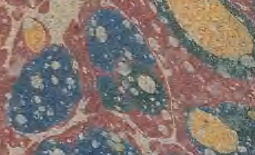

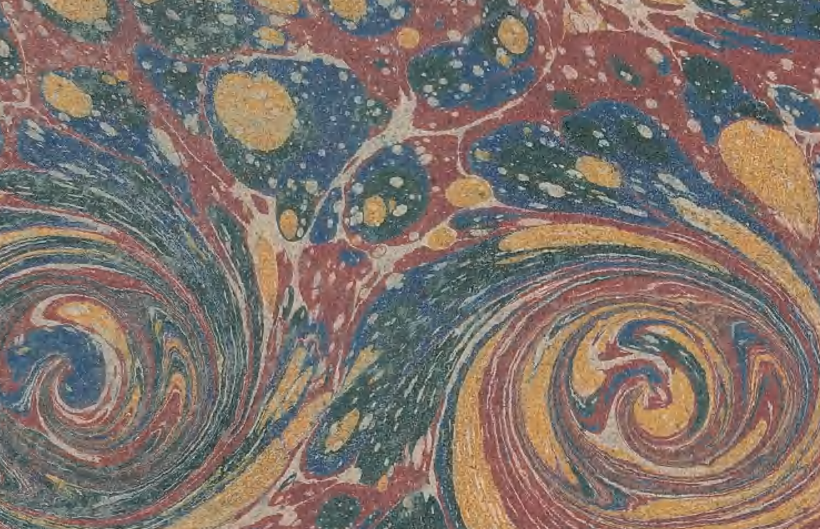

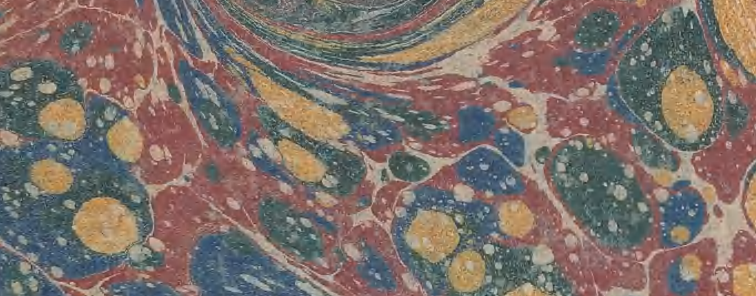

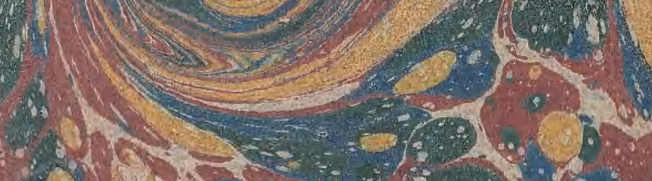

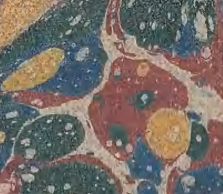

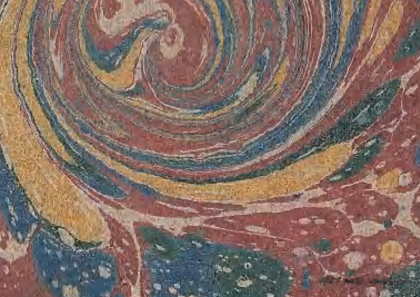

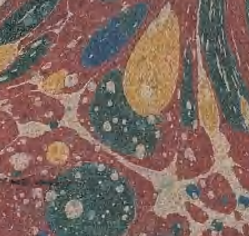

(a)

)

$1,0^{2}, 5$

2.

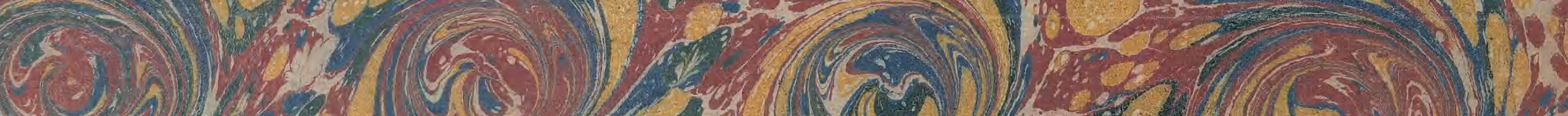
(1.6)

W.

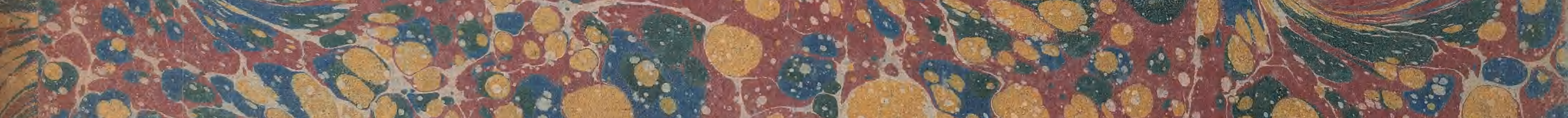

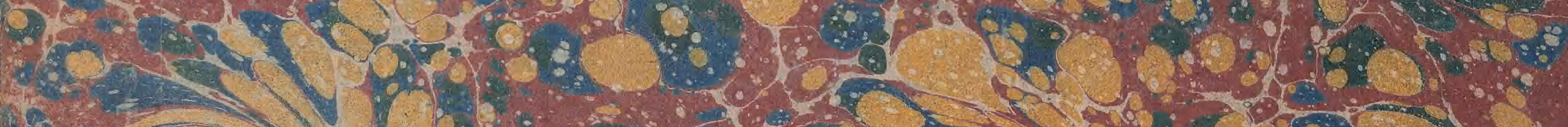

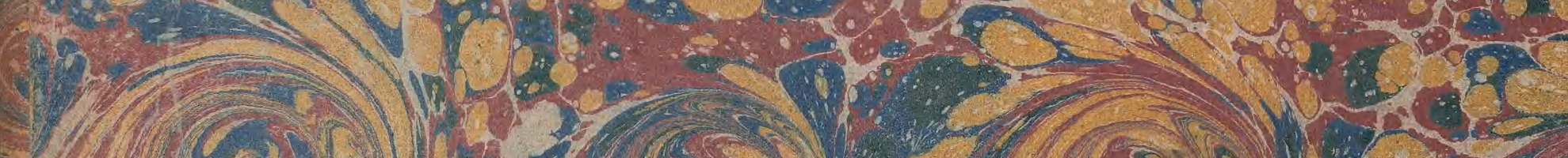
$((2))(2))^{2}(2-2=$
$\sqrt{(0,3)})(2,0)$
(a)

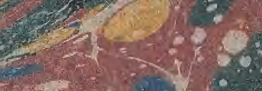

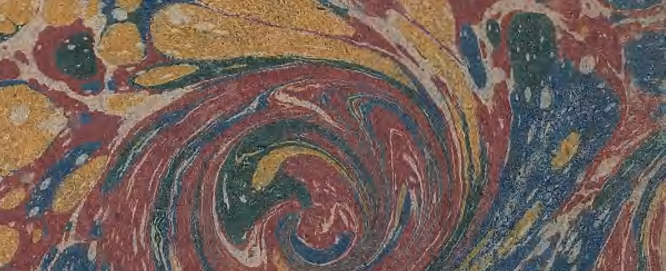

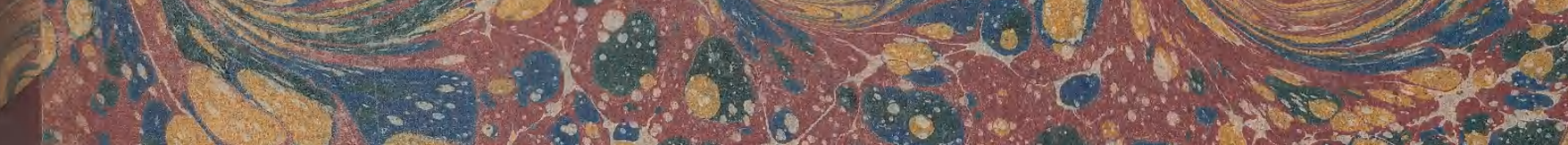

- $=2+30$ 


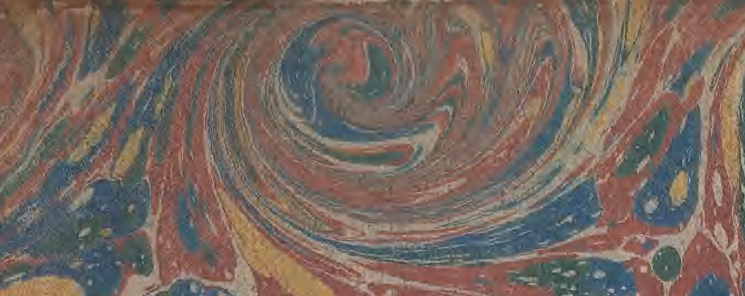





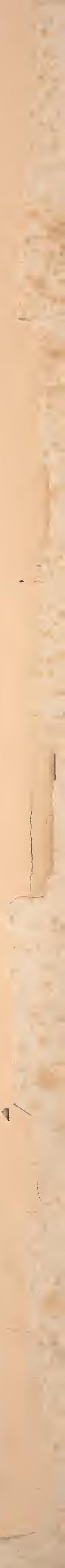





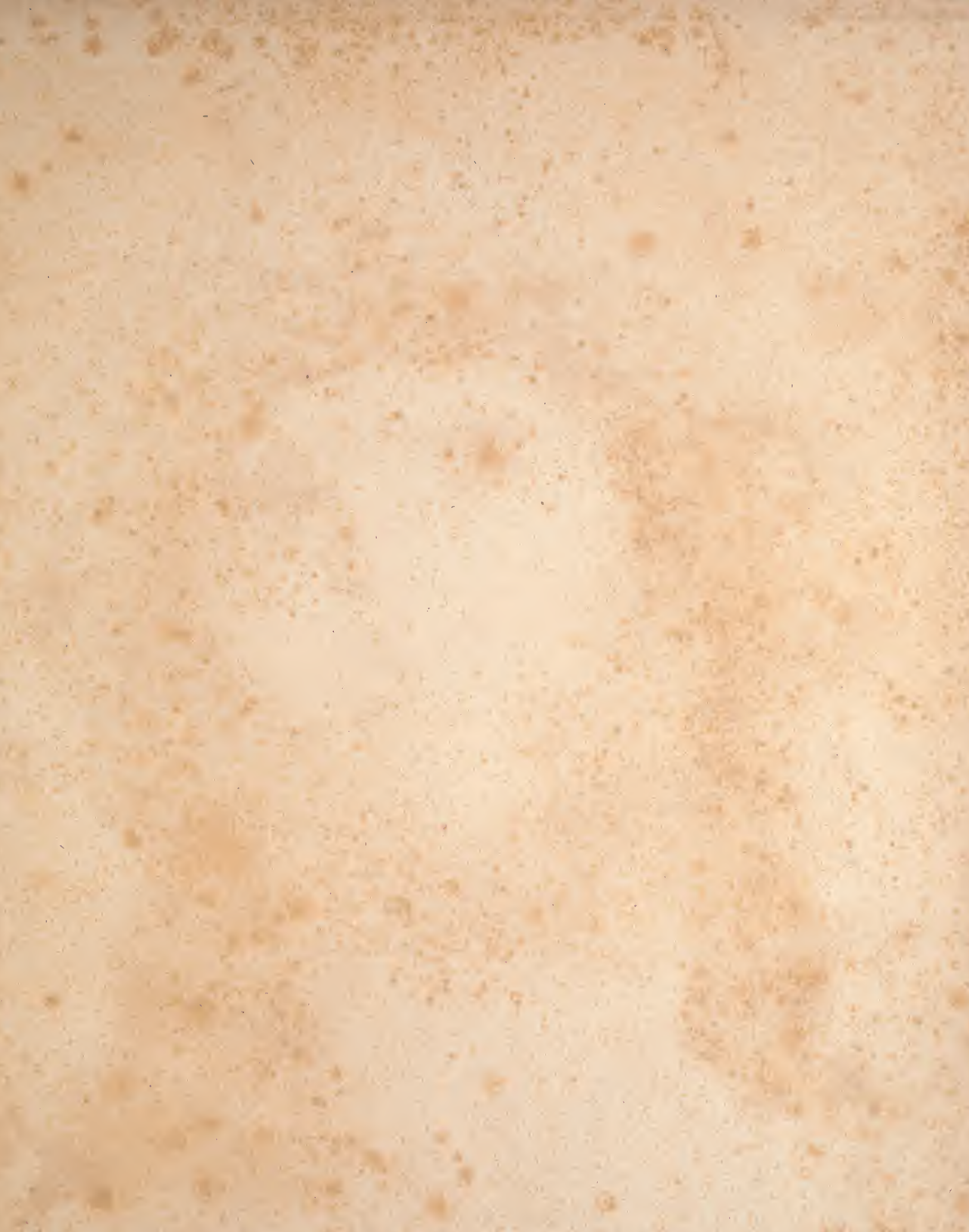




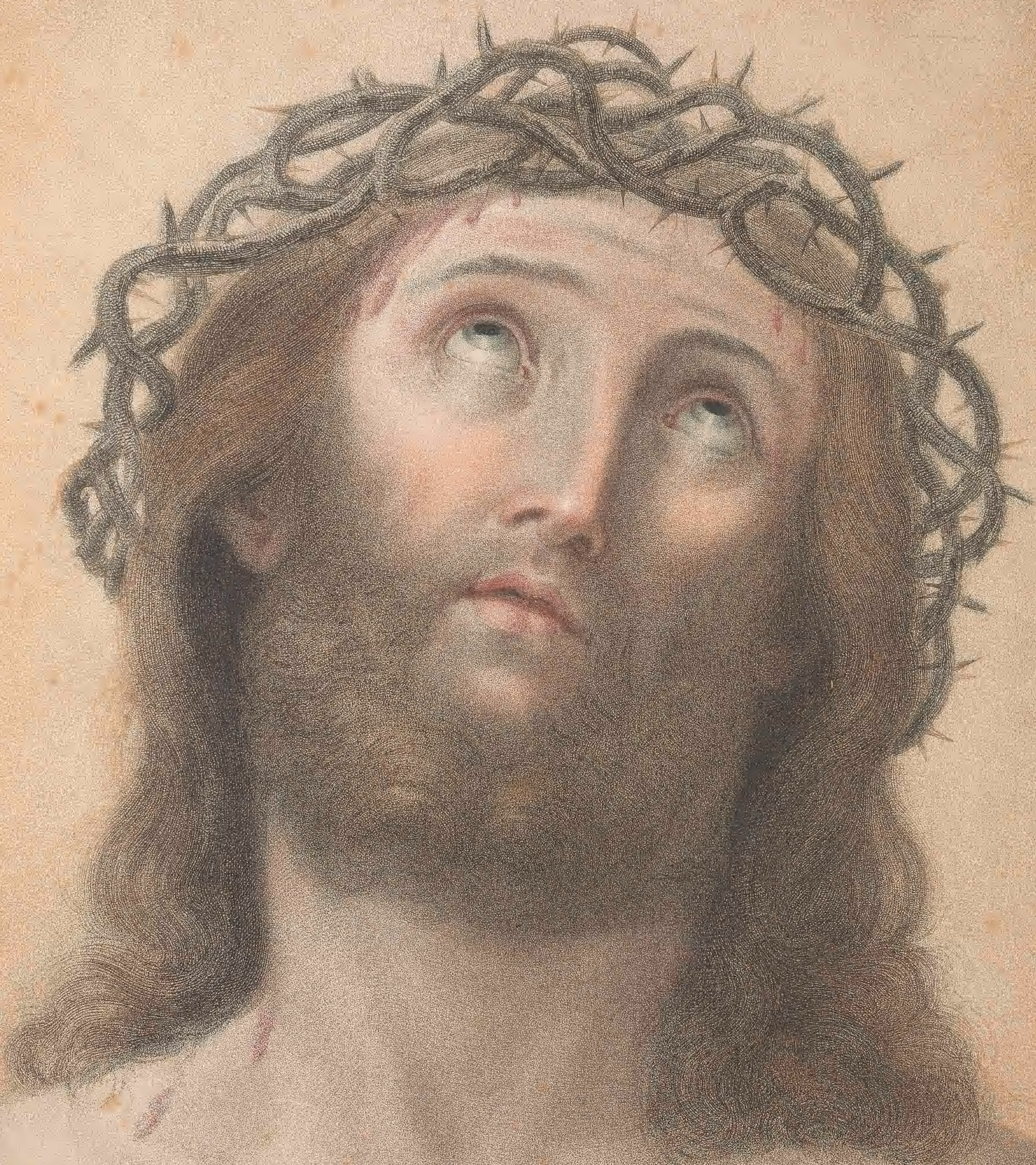


$x$ 


\section{ORIGINAL DESIGNS}

OF

THE MOST GELEBRATED MASTERS

OF THE

\section{B O L O G NESE, R O MA N, F L O R E N T I NE, AND VENETIAN SGHOOLS;}

COMPRISING SOME OF THE WORKS OF

LEONARDO DA VINCI, THE CARACCI, CLAUDE LORRAINE, RAPHAEL, MICHAEL ANGELO, THE POUSSINS, AND OTHERS,

\section{IN HIS MAJESTY'S COLLECTION;}

ENGRAVED BY

BARTOLOZZI, P.W. TOMKINS, SGHIAVONETTI, LEWIS, AND OTHER EMINENT ENGRAVERS;

WITH

BIOGRAPHICAL AND HISTORICAL SKETCHES OF L. DA VINCI AND THE CARACCI.

BY

J. CHAMBERLAINE, F. S. A.

AND KEEPER OF THE KING'S MEDALS AND DRAWINGS.

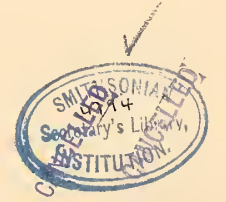

\section{LONDON :}

PRINTED BY W. BULMER AND CO. SHAKSPEARE-PRESS, CLEVELAND-ROW;

AND SOLD BY G. AND W. NICOL, BOOKSELLERS TO HIS MAJESTY, PALL-MALL; WHITE AND COCHRANE, FLEET-STREET; AND COLNAGHI AND CO. COCKSPUR-STREET. 


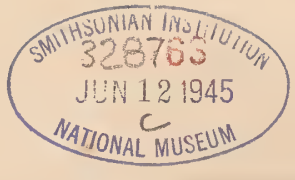




\title{
IMITATIONS
}

\author{
OF

\section{O R I G I N A L D E S I G N S}

\author{
BY LEONARDO DA VINGI:
}

GONSISTING OF

\section{VARIOUS DRAWINGS}

OF SINGLE FIGURES, HEADS, COMPOSITIONS, HORSES, AND OTHER ANIMALS;

OPTICS, PERSPEGTIVE, GUNNERY, HYDRAULIGS, MEGHANIGS;

AND IN PARTICULAR OF

Very aCGURATE deLineations, with A MOST SPIRited PEN,

OF A VARIETY OF

ANATOMIGAL SUBJEGTS:

IN HIS MAFESTY'S GOLLEGTION.

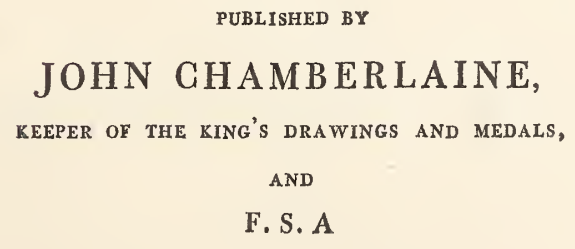

1796. 

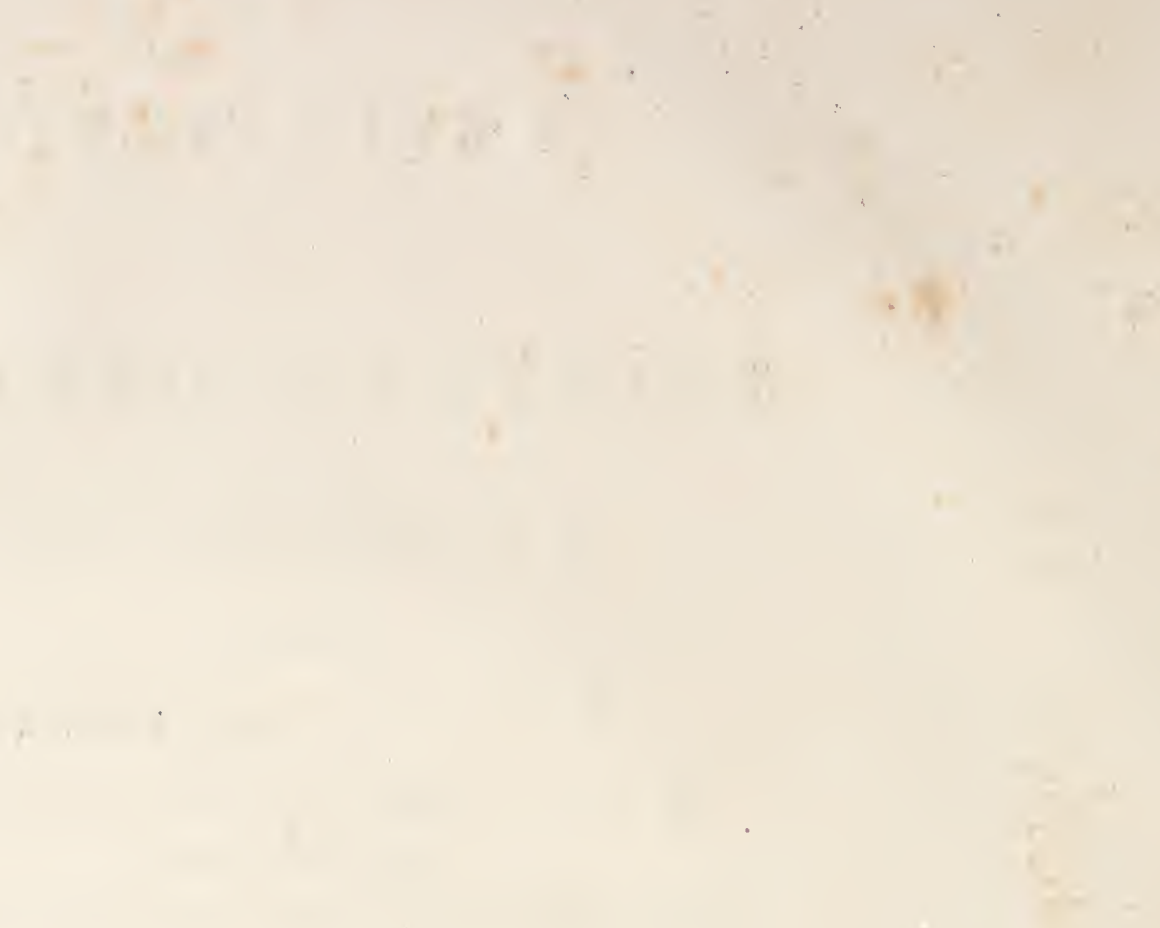

t 


\section{TO THE KING.}

$S I R$,

With all humility, I presume to avail myself of your Majesty's gracious permission, to lay at your feet, a Collection of Imitations of some interesting works of Leonardo da Vinci, in your Majesty's Collection.

A publication which will display, together with the most exquisite efforts of taste, a knowledge of natural and experimental philosophy, which would have done honour to a more enlightened age, seems to have a just claim to the protection of your Majesty, through whose distinguished munificence the Arts, and Sciences, have arrived at a point of excellence, in this country, unparalleled at any former period.

Encouraged by this consideration, I venture with less difficulty to crave your Majesty's auspicious patronage to the memory of so great an Artist; and, under - the shelter of his transcendent merit, to offer this humble testimony of the profound duty and gratitude which I so peculiarly owe to your Majesty, and with which I shall ever remain,

SIR,

Your Majesty's most dutiful Subject,

and faithful Servant,

JOHN GHAMBERLAINE. 


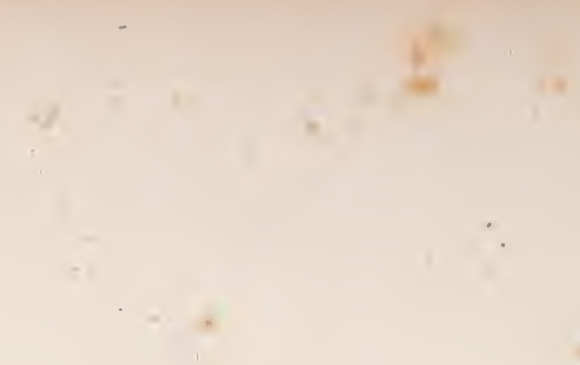




\section{LEONARDO DA VINGI.}

$\mathbf{T}_{\text {HIs admirable Artist attracted, by the brilliancy of his genius, the notice of }}$ his contemporaries, and ensured the esteem of posterity, by the versatility of his talents, and the elaboration of his works. He was not one of those men, who rise to greatness during an age, which has neither rivals to struggle for superiority, nor discernment to award the palm of pre-eminence. He, indeed, must be allowed to have been a master of his art; who, while he was yet a pupil, surpassed Verocchio his instructor, who divided the suffrages of Italy, during the pontificate of Leo the Tenth, with Michael Angelo; and who, at the same time, drew the admiration, without the envy, of Raphael.

Leonardo da Vinci, was born in the year 1444, in the castle of Vinci, which is situated in the vale of Arno, at no great distance below Florence. The castle no longer confers distinction on the artist, but the artist gives distinction to the castle. He was the son of Pietro da Vinci, a gentleman of narrow fortune, who observing Leonardo's genius for painting, from his infantine sketches, resolved to cultivate the propensities of his nature, by giving him the help of art. With this design, Pietro da Vinci placed his son under the instruction of his friend Andrea Verocchio of Florence, who was not only a painter and engraver, but a carver, a goldsmith, and an architect. The good qualities of the pupil engaged the assiduous attention of the master. But, the vigour of Leonardo's genius soon surpassed the performances, while his discretion did not disregard the precepts, of his instructor. The monks of Valombrosa, near Florence, having employed Verocchio to paint the Baptism of our Lord, were the unconscious instruments of making this unwelcome discovery. Leonardo being employed on this occasion by his master to paint the angel, performed his task with such felicity of design, and superiority of execution, as to throw his master's parts of the picture into shade; to gain envied admiration for his own; and thereby to induce Verocchio to drop the pencil, which, if tradition may be credited, a sense of inferiority made him relinquish for ever. The scholar immediately assumed the pencil, which the master had in this manner thrown away in despair. 
Leonardo now entered the world with the hopes of youth, to court approbation by the grace of his manners, and to obtain fame by the variety of his powers. Few artists will be found to have been more successful in attracting notice, and gaining celebrity. After painting for some time at Florence, his reputation as a painter, and his fame as a man, spread over Italy, the most accomplished nation in Europe, during that age. He was ere long admired for talents, the most useful as well as ornamental. Lewis Sforza, the Duke of Milan, was by these means induced to invite this extraordinary genius to his court, in order to profit from his talents. The Duke immediately appointed him superintendant of the academy of architecture, which had lately been revived, with additional encouragement, and splendour. Leonardo no sooner assumed his charge, than he exploded the Gothic modes, which having been introduced into the old academy by Michalino, had existed for a century, and directed every practice according to the Roman simplicity, and the Grecian grace.

The Duke of Milan, knowing the extent of Leonardo's capacity, and variety of talents; being desirous of converting both to the use, as well as to the ornament of his country; engaged this illustrious mechanist in the noble project of conducting the waters of the Adda, from Mortesana, through the Valteline, and the valley of Chiavenna, to the walls of Milan; being an extent of two hundred miles. Leonardo entered on this design with his usual ardour. He is said to have retired a while to the seat of his friend Sig. Melzi, at Vaverola, where he might study in quiet those parts of the mathematics, which are most applicable to mechanics. He looked into history for a knowledge of antiquity. During a research, which added the lessons of experience to the precepts of theory, he observed how the Ptolemys had conducted the waters of the Nile, for the accommodation of Egypt, and he at the same time saw the manner, in which Trajan had opened a communication between Nicomedia and the sea, by making navigable the intervenient waters. All difficulties disappeared before the efforts of genius, which was thus improved by study, and conducted by experience.

While the Adda was in this manner constrained to benefit Milan by a commodious aqueduct, as the Tesino had been rendered tributary, two hundred years before; the Duke was equally zealous to adorn his metropolis by Leonardo's pencil. The prince desired him to ornament the refectory of the 
Dominicans of Sta. Maria del Gratie with a painting of our Lord's Supper. The painter chose that interesting part of the history, wherein our Saviour declared to the Apostles, that one of them would betray him. In this masterpiece of his art, Leonardo has shown how well he knew how to exhibit the various expressions of grief, love, fear, suspicion, and villainy. Being disturbed, while he was performing this great work, by the impatience of the prior; the painter is said to have artfully introduced the tasteless priest into the group, in the character of Judas, with the characteristick features of an odious traitor. The head of our Saviour he never finished, being unable, as it is conjectured, to express completely his own conception of God incarnate. Even the rivality of artists has acknowledged, that Leonardo surpassed himself in this matchless performance. The design is allowed to be grand, and correct; the heads are admitted to be admirably varied; the expression noble, and the colouring fine. Of this inimitable specimen of the art, copies only remain. There is, however, happily preserved, in his Majesty's collection, the original drawing for this great performance. Leonardo dignified this refectory with other pictures, and also painted for the Duke, his patron, our Lord's Nativity, which happily remains to this day, in the Emperor's cabinet, as one of its greatest ornaments.

Whilst thus occupied, Leonardo frequently retired to Vaverola, the villa of his friend Sig. Melzi, where he found, in the bosom of friendship, his repose neither interrupted by the visits of admirers, nor his studies incommoded by the cares of the Academy. It was in this friendly retreat, wherein he enjoyed perfect ease, that he composed the greatest number of his works. It was here that he studied anatomy; that he held frequent conferences with Marc Antonio della Torre, the professor of anatomy at Pavia, where he dissected with his own hand, and diligently made those spirited designs from nature, which were afterwards formed into a collection by Melzi. His skill in that useful science proved of infinite service to himself, by enabling him to give a peculiar force to his figures; and will, I flatter myself, prove a lasting benefit to the world, by stimulating other artists to imitate his diligence, and to emulate his skill. He drew a book of Combats, for the use of Sig. Borommeo, a fencing master, in which he represented the several kinds of engagements, both on horseback, and on foot. He composed various treatises for the instruction of the painters of the new academy, which, through his uncommon care, was 
then in a very prosperous state. From this detail he appears to have been a diligent student himself, and an active promoter of the studies of his imitative disciples.

Biographers, in order to do justice to his creative faculties, have preserved a little circumstance, which exhibits Leonardo's mechanick powers in a new, though less splendid, light. In 1499, when Lewis XII. was about to enter Milan, the magistrates requested our artist to contrive some device for his entertainment. Leonardo gratified their wishes, and showed his own ingenuity, by making an automaton, which represented a lion, a beast so courageous as to march up to the French king, and so civil, as to open its breast, in order to exhibit the royal escutcheon, with the national fleurs des lis. Trifles, when they are performed by those, who can execute the greatest works, gratify curiosity; and when they exhibit an uncommon personage in a new, and attractive situation, they illustrate character.

But "grim-visaged War" appearing now in Lombardy, frightened, into safer regions, Peace, "the dear nurse of arts, plenties, and fruitful births." In that sad event were involved the Duke of Milan, first, and Leonardo afterwards. In the fatal year 1500, was our artist's patron, and the encourager of talents, overthrown in battle by the French, taken prisoner, and carried into France, where he died in the castle of Loches. These disastrous events destroyed the Academy of Milan, dispersed the profefsors, and banished the arts from that nursery of genius. Leonardo lost every thing, except his capacity, application, and attractions. Yet, those misfortunes proved advantageous to Italy; Leonardo's scholars settling in every town, and benefiting every community by their talents and labours. He had made painters, carvers, architects, founders, and engravers in precious stones. Out of this school went Francis Melzi, Cæesar Sesto, Bernard Lovino, Andrew Solcino, Mark Uggioni, Anthony Boltroffo, Gobbo, an extraordinary painter and carver; Annibal Fontana, a worker in marble and precious stones; Bernazzo, an excellent painter of landscapes; Paul Lomazzo, and other ingenious men. Happy is it for mankind, that partial evil, which will sometimes derange the system of life, should produce by its effects a general good, which overbalances the private inconvenience!

The misfortunes of Milan obliged Leonardo to retire to Florence, where the useful and the ornamental arts were now cultivated under the genial influence of the Medici. In this shelter from the storms of war, the first object of 
our painter's diligence was an altar-piece for the Annunciata. By this performance, he gained the applause of Florence. Though he may have obtained little profit, he acquired great popularity, where he had happily spent his youthful years, and had first been charmed by the voice of praise, and early incited by the flatteries of hope. But, he seems to have laboured with the most pleasure on the picture of Mona Lisa, which is usually called la Gioconda; and which painters have spoken of as a divine piece. He painted also a Flora, which emulates the Lisa. His pencil continued to adorn the palaces, or to gratify the nobles of Florence, by pictures, which had been deemed masterpieces of the art, had they come from any other pencil than Leonardo's.

Such was now his reputation, that the Florentines resolving, in 1503, to adorn their Council Chamber, appointed Leonardo, by a publick decree, to execute that agreeable task. But felicity seldom lasts long. He had the mortification to observe, when he had almost finished one side of the apartment, that his colours, as fast as they dried, loosened from the wall. He at the same time experienced another vexation, which was less within his own power to remedy, and more lasting in its consequences. Michael Angelo, who had acquired a great reputation in his early years, was appointed, at the age of twentynine, to assist Leonardo, at fifty-nine. Like the rivals in the Roman state, the one could not bear an equal, nor the other a superior. The rivalry of these illustrious painters, divided Florence into parties, who, as usual on such occasions, embittered their jealousies, without attempting to reconcile their enmities. The fame of this great contest of skill, and emulation, drew Raphael from the school of Perugino, to Florence. When Raphael contrasted the works of Leonardo, with Perugino's paintings, he was struck with astonishment. The delicacy and grace of Leonardo's style, when compared with the hard and dry manner of Perugino, gave the youthful master a high gratification, and inspired him with a new taste. It proves the rectitude of Raphael's judgment, that he could immediately renounce the bad habits of his school, and adopt a better style. It is to this judgment, to the example, and instructions, perhaps, of Leonardo, that Raphael attained to the perfection of his art, and left behind him many specimens, which, for the softness and delicacy of his figures, are to this day, without example, or rivalry.

Leonardo continued to live at Florence, gratified, no doubt, by Raphael's imitations of him, notwithstanding the vexatious treatment of Michael Angelo. 
Of all his works at this period of his life, two pictures are only remembered; the Virgin with her Infant, and a Baptist's head.

Rome had hitherto no attractions for Leonardo, while he had no leisure for visiting Rome. The exaltation of Leo X. to the pontificate gave him an occasion however of visiting, in 1513, that venerable mistress of the world. He appears to have been received here with less attention than was due to his merits, or was satisfactory to his expectations. Owing to whatever cause, Leo treated our artist with disregard; saying, what he had probably heard at Florence, that he could expect nothing from a painter, who thought of finishing his works, before he had begun them.

Leonardo soon grew weary of Rome, since Rome was inattentive to Leonardo. The truth probably is, that being now old, he was unable to contend with such rivals as Michael Angelo, and Raphael, who were supported by fashion, a mistress, who is ever enamoured with youth, and always delights in change.

Leonardo was, in this manner, induced to accept the invitation, which he had received from Francis I. At his advanced age, he was enabled by hope, to perform his journey to France in 1514. He was received by that splendid monarch at Fontainebleau, with the most flattering attention. What was of more importance to our painter, at the age of seventy, the generosity of Francis made his mode of life easy to him, though the artist was too feeble, from age and infirmities, to be able to execute works of considerable magnitude. The fatigues of his voyage, and the change of climate, are supposed to have brought on the distemper which, at the end of four years, carried him to his grave. After languishing a while, amid the king's attentions, he made his will, with the royal assent, on the twenty-third of April, 1518, whereby he bequeathed to M. Franceso di Melzo, a gentleman of Milan, all his books, papers, and instruments, which related to the art of painting. At the age of seventy-five, he died at Fontainebleau, on the second of May, 1519, enjoying in his last moments the satisfaction of beholding that monarch's goodness to him; for it is confidently related, that the prince, making him a visit during his illness, and Leonardo, exerting himself beyond his strength, to evince his gratitude for such condescension, fell into the monarch's arms, in which he expired, oppressed by his weakness, and overpowered by his feelings. He was followed to his tomb, by the universal regret of the enlightened part of Europe, when rivalry had ceased, and enmity was vain. 
Such was the end of one of the most uncommon men, the world has ever produced.

Of Leonardo it has been said, with hyperbolical praise, that he enjoyed from nature, all which nature can give. He certainly had a very handsome person, which he was studious to adorn with every accomplishment of art. He was blessed with athletick strength, and he was diligent to invigorate it by bodily exercises, which, as he performed with dexterity, gained him popular applause. During his riper years, when he had relinquished all thoughts of marriage, he allowed, with careless inattention, his hair and beard to grow in wild luxuriance, till he appeared, at length, with the venerable intelligence of an ancient Druid. He seems to have been delighted with this appearance; for, as Vasari assures us, from good authority, Leonardo made a sketch of his own head, in this character, which remained among his drawings. This invaluable sketch is happily preserved in his Majesty's collection, and is prefixed to the following work, by the King's liberal permission. In the engraving of Bartolozzi, which is worthy of the original, we see the prevailing features of Leonardo's mind, mildness and knowledge. In the eye, is portrayed his vivacity and penetration. To politeness and address, there were united in that universal genius, great strength and elevation of mind; a never-failing energy, and unwearied application; extensive learning, and pleasant conversation. He not only played on the lyre, but he invented one of an improved construction : and in addition to all those extraordinary accomplishments, he had a taste for poetry. With regard to a man of such universality of talents, and habits of diligence, it may be easily supposed that his writings must have been numerous.

1. He wrote a Treatise on Hydraulicks. This work contains many draughts of machines, for conveying, raising, and supporting water.

2. A Treatise of Anatomy. This work is likewise embellished with a great number of draughts, which were all carefully drawn from nature; some of which are now submitted to the publick, for the benefit of students in the various branches of anatomical study.

3. The Anatomy of a Horse; which is mentioned by Vasari, Borghini, and Lomazzo. Leonardo had a peculiar talent, in drawing that noble animal, and designed this treatise for the use of those who paint battles, or triumphs.

4. A Treatise of Perspective. In this work, Leonardo teaches the mode of drawing figures larger than the life, which is so greatly praised by Lomazzo. 
5. A Treatise of Light and Shadow; which remains in the Ambrosian library at Milan. The author treats this useful subject as a philosopher, a mathematician, and a painter. Leonardo shows how well qualified he was to discuss these topicks, by his knowledge of the effects of lights and colours, which he managed in his practice with unrivalled skill.

6. Of Leonardo, the principal work, is an excellent Treatise on Painting. The Italian copy was first published at Paris in 1651; it was printed the same year in a French translation, by R. du Fresne, with figures by Nicolas Poussin, in folio; and it was reprinted at Paris in 1716, in duodecimo. From this last edition, the Treatise of Painting was translated into English, and published by John Senex, London, 1721, in octavo. This is the only work of Leonardo, which, till now, has been ever laid before the publick; though his writings have been often mentioned, and always with applause.

It may appear presumptuous in me, to offer to an enlightened publick, this sketch of the life, and specimens of the works, of Leonardo da Vinci : yet must my good intentions be my best apology. I was urged by an ardent desire to gratify the lovers of the arts, by multiplying the fine performances of that great master, at a period, when they can be imitated in a style, which is not unworthy of Leonardo's excellence. I was encouraged by the favourable opinions of the late Dr. William Hunter, the physician, and John Hunter, the surgeon, as well as by some of the ablest anatomists of the present day, with regard to the utility of such a publication; and my previous desire was carried into final resolution, by the gracious facility, with which his Majesty gave his permission to publish, from the works of Da Vinci, in the Royal Gabinet, whatever might be deemed either useful, or ornamental, to his people.

It may gratify curiosity, to inform the reader, how any part of the works of Leonardo, should have contributed to ornament his Majesty's collection. The whole of the artist's labours were bequeathed by will, to Sig. Melzi, as a grateful tribute of sincere friendship. After his decease, they were collected into thirteen volumes, and deposited at Vaverola, where they had been chiefly composed. Here they remained, after the decease of Melzi, Leonardo's legatee, in the possession of his infant heirs. From these children, were those invaluable treasures obtained by the unfair pretences of Gavardi, their tutor: but he was induced by the zealous representations of Mazzenta to return the whole to Horatio Melzi. In a moment of unconscious 
ignorance, or absurd gratitude, the rich bequest of Leonardo was given back by Horatio Melzi, to Mazzenta. But, being made sensible at length by Pompeo Leoni, the statuary of the king of Spain, of the real value, and infinite importance, of what he had bereaved his family, Melzi prevailed on Mazzenta to redeliver to him seven of the thirteen volumes; of the other six volumes, Cardinal Borromeo had one volume, which is now in the Ambrosian library; Ambrose Figgini had another, which has since descended to Hercules Bianche, his heir; Charles Emanuel the Duke of Savoy, had a third volume; and the other three volumes, became the property of Pompeo Leoni, by whose heir they were sold to Graleazzo Lonato.

In this manner, were the last wishes of Leonardo frustrated, either by accident, or design, to gratify the world, and extend his fame.

It was one of the three volumes, which became the property of Pompeo Leoni, that is now in his Majesty's cabinet. It is rather probable than certain, that this great curiosity was acquired for King Charles I. by the Earl of Arundel, when he went ambassador to the Emperor Ferdinand II. in 1636, as may indeed be inferred from an instructive inscription over the place, where the volumes are kept, which sets forth, "that James, King of England offered "three thousand pistoles for one of the volumes of Leonardo's works." And some documents in the Ambrosian library give colour to this conjecture. This volume was happily preserved, during the civil wars of the last century, among other specimens of the fine arts, which the munificence of Charles I. had amassed with a diligence equal to his taste. And it was discovered soon after his present Majesty's accession, in the same cabinet where Queen Caroline found the fine portraits of the court of Henry VIII. by Hans Holbein, which the King's liberality permitted me lately to lay before the publick.

On the cover of this volume is written, in gold letters, what ascertains its descent; Disegni di Leonardo da Vinci restaurati da Pompeo Leoni.

It consists of a variety of elegant heads, some of which are drawn with red and black chalks, on blue, or red paper; others with a metal pencil on a tinted paper; a few of them are washed and heightened with white; and many are on common paper. The subjects of these drawings are miscellaneous; as portraits, caricatures, single figures, tilting, horses, and other animals; botany, opticks, perspective, gunnery, hydraulicks, mechanicks, and a great 
number of anatomical subjects, which are drawn with a most spirited pen, and illustrated with a variety of manuscript notes.

This volume contains, as has already been mentioned, what is of more importance, the very characteristick head of Leonardo, as it was sketched by himself; and now engraved by that eminent artist, Mr. Bartolozzi. 


\section{COPIA.}

1. Quali sono le parti dell' uomo dove la carne non cresce mai per alcuna grassezza, e quali son quelli lochi dove essa carne moltiplica più che in alcun altro loco.

2. Farai la prima dimostrazione delle coste con 2 figurazioni senza la spatula e poi altre due colla spatula.

3. Figura prima la fronte della spatula, senza il polo $m$. del braccio, e poi farai il braccio,

4. Fa una dimostrazione di tali coste nella quale si dimostri la torace di dentro, e cosi una dimostrazione che abbia levato la torace, e mostri la spina del dorso della parte di dentro.

5. Fa vedere queste due spatule e cosi situate, di sopra, di sotto, in faccia, dirieto e dinanzi.

6. Dalla prima costa $\Lambda$. alla quarta di sotto $d$. è pari alla padella della spalla $o . p$. ed è simile alla palma della mano e al piè dal suo polo alla punta d' esso piedi, e ogni cosa insieme è simile alla lunghezza del viso.

7. Prima che tu ponga l' osso del braccio $m$. figura la fronte della spalla che lo riceve, colla concavità della spatula; cosi fa in ogni giuntura—Spondili 5 .

8. La spatula piglia l' osso del braccio da due lati e dal terzo lato presso dell' osso della forcula del petto.

9. Figura prima la spalla senza l'osso $\Lambda$, e poi ve lo metti.-Nota come li muscoli ligano insieme le costole.

10. Dimostra l'osso dell' ajutorio come la sua fronte s' incassa nella bocca della spatula, e la utilità d' essa spatula, e della parte $\Lambda$, dove si congiungon li muscoli alle costole.

11. Farai una seconda figurazione dell' ossa nella quale si mostri l'appiccatura de' muscoli sopra esse ossa.

12. La forcula solamente si move collo stremo a e fa-con quello gran movimento infra su e giù.

13. Figurerai le coste co' loro spazj traforati dove sopra di loro termina la spatula.

\section{TRANSLATION}

1. Which are the parts of man, where the flesh never increases by any fatness, and which are those places where that flesh accumulates more than in any other place.

2. You will make the first demonstration of the ribs by two figurations without the shoulder blade, and then two others, with the shoulder blade.

3. First draw the front of the shoulder blade, without the pole $m$. of the arm, and then make the arm.

4. Make a design of such ribs, in which is shown the inside of the thorax or chest, and also a design without the chest, and show the spine of the back withinside.

5. Cause the two shoulder blades to be so situated, as to be viewed above, beneath, in front, behind, and before.

6. From the first rib $\wedge$, to the fourth beneath marked $d$, is equal to the blade of the shoulder, likewise to the palm of the hand; and from the bottom of the head of the humerus to the lower point of the scapula, and each of these proportions are the length of the face.

7. Before you place the bone of the arm $m$, display the front of the shoulder, which receives it, together with the concavity of the shoulder blade, do the same thing in every joint, - the five processes of the vertebræ of the neck.

8. The spatula receives the bone of the arm in two sides, and in the third side near the bone of the furcella of the breast.

9. First make the drawing of the shoulder without the bone marked $\wedge$, and afterwards add it. Note how the muscles tie the ribs together.

10. Show the inside of the humerus; how its front is cased within the cup of the spatula, and of the part marked $\wedge$, where the muscles join with the ribs.

11. You will make a second design of the bone, and show how the muscles are attached to that bone.

12. The forcula only moves the head from the extremity of the collar bones, with great action below, upwards and downwards:

13. You will draw the ribs with their spaces pierced, where the shoulder blade ends, which is placed upon them. 
1. Farai tutti li moti dell' ossa colle giunture loro dopo la dimostrazione delle prime tre figure dell' ossa, e questo si de' fare nel primo libro.

$$
\text { * Schiena. }
$$

2. Spalla da rovescio che veste le coste dirieto alle spalle. Fa prima l'osso delle coste.

\section{+ Dimestica.}

3. $m$. n. è un altro muscolo che si interpone infra la cartilagine che veste e colliga le coste al muscolo $n$. ch' è dentro alla padella della spalla ov'è il muscolo $n$.

4. Figura le coste d' onde la spatola $n$. si spicca.

5. Li muscoli $n$. $m$. son causa del moto ancor volubile dell' aiutorio.

Mostra qui quali muscoli son causa dell' alitare che si fa colli muscoli e nervi che sono attaccati alle costole di fuori.

6. Di tutte le figure la lor vera notizia si possiede col sapere di quelle la larghezza, la lunghezza e la profondità. Adunque se io noto il medesimo della figura dell' uomo, io darò di quella vera notizia appresso d'ogni sano intelletto. Comenta le párole perchè sono confuse.

7. Falla due tanti maggiore colla medesima grossezza di coste e muscoli e sarà più intelligibile.

8. Ancora questa figura sarebbe confusa se prima non facessi almeno tre dimostrazioni innanti a questa di simili fili; delle quali dimostrazioni la prima debbe essere delle sem. plici ossa; dipoi seguitin li muscoli che nella tetta nascono sopra le coste; e in ultimo li muscoli che nascono della torace insieme colle sue coste: in ultimo queste qui di sopra.

9. Fa le coste tanto sottili che nell' ultima dimostrazion fatta co' fili là spatula possa dimostrare il suo sito.

10. Innanti che tu formi li muscoli fa in luogo di quelli fili li qua' si abbino a dimostrare, li fili d' essi muscoli, li quali co' loro stremi termineranno nel mezzo dell' appiccatura de' muscoli sopra le loro ossa. E questa farà più espedita cognizione quando tu vorrai figurare tutti li muscoli l' uno sopra dell' altro, e se farai altrimenti, la tua figurazione fia confusa.
1. Make all the movements of the bones with their joints after the design of the three first figures of the bones; and this ought to be done in the first book.

$$
\text { * Back. }
$$

2. The inside view of the shoulder blade, which covers the back part of the ribs. First make the bones of the ribs.

$$
+\ldots . .
$$

3. $m . n$. is another muscle which interposes itself between the cartilage which covers and connects the ribs to the muscle $n$. which is in the padella of the shoulder, where is the muscle $n$.

4. Draw the ribs from which the shoulder blade $n$. detaches itself.

5. The muscles $n . m$. are likewise the cause of the voluble motion of the helping muscle,-show here which muscles are the cause of the respiration which is made by the muscles and nerves, which are fastened to the outside of the ribs.

6. The true knowledge of all the figures is acquired by knowing their breadth, length, and depth. If therefore I note the same in the human figure, I shall give a true knowledge of it to any person of sound understanding. Comment upon these words because they are confused.

7. Make two larger, with the same thickness of ribs and muscles, and it will be more intelligible.

8. This design would likewise be confused, if you did not make at least three demonstrations before this, which is composed of similar filaments; the first of which should be of the bones only, the second of the muscles which spring from the pap upon the ribs; the third of the muscles which arise from the thorax, together with the ribs; and lastly those as above.

9. Make the ribs so thin that in the last demonstration made with the ligaments, the place of the spatula may be seen.

10. Before you form the muscles, put in the place of those filaments which are to be demonstrated, the filaments of those very muscles which with their extremities end in the centre of the attachment of the muscles upon their bones; and this will give the most ready intelligence when you would figure all the muscles, one upon the other: and if you do otherwise, your designs will be confused. 


\section{ENGRAVINGS}

\section{FROM THE \\ ORIGINAL DESIGNS}

OF

\section{ANNibAle, Agostino, AND LUdoviGo \\ G A R A C C I,}

IN HIS MAFESTY'S GOLLEGTION.

CONSISTING OF

ELEGANT GOMPOSITIONS AND STUDIES

FOR THE

\section{VARIOUS CELEBRATED PIGTURES}

IN THE DIFFERENT PALACES AND GABINETS

AT

ROME, BOLOGNA, PARMA, MILAN, \&c.

RUBLISHED BY

JOHN CHAMBERLAINE, F.S.A.

AND

KEEPER OF THE KING'S MEDALS

AND DRAWINGS.

\section{LONDON:}

PRINTED BY W. BULMER AND CO.

AND SOLD BY GEORGE NICOL, BOOKSELLER TO HIS MAJESTY;

EDWARDS, PALL-MALL; ROBSON, BOND-STREET; AND MESSRS.

WHITE, FLEET-STREET.

1797. 


\section{G O N T E N T S.}

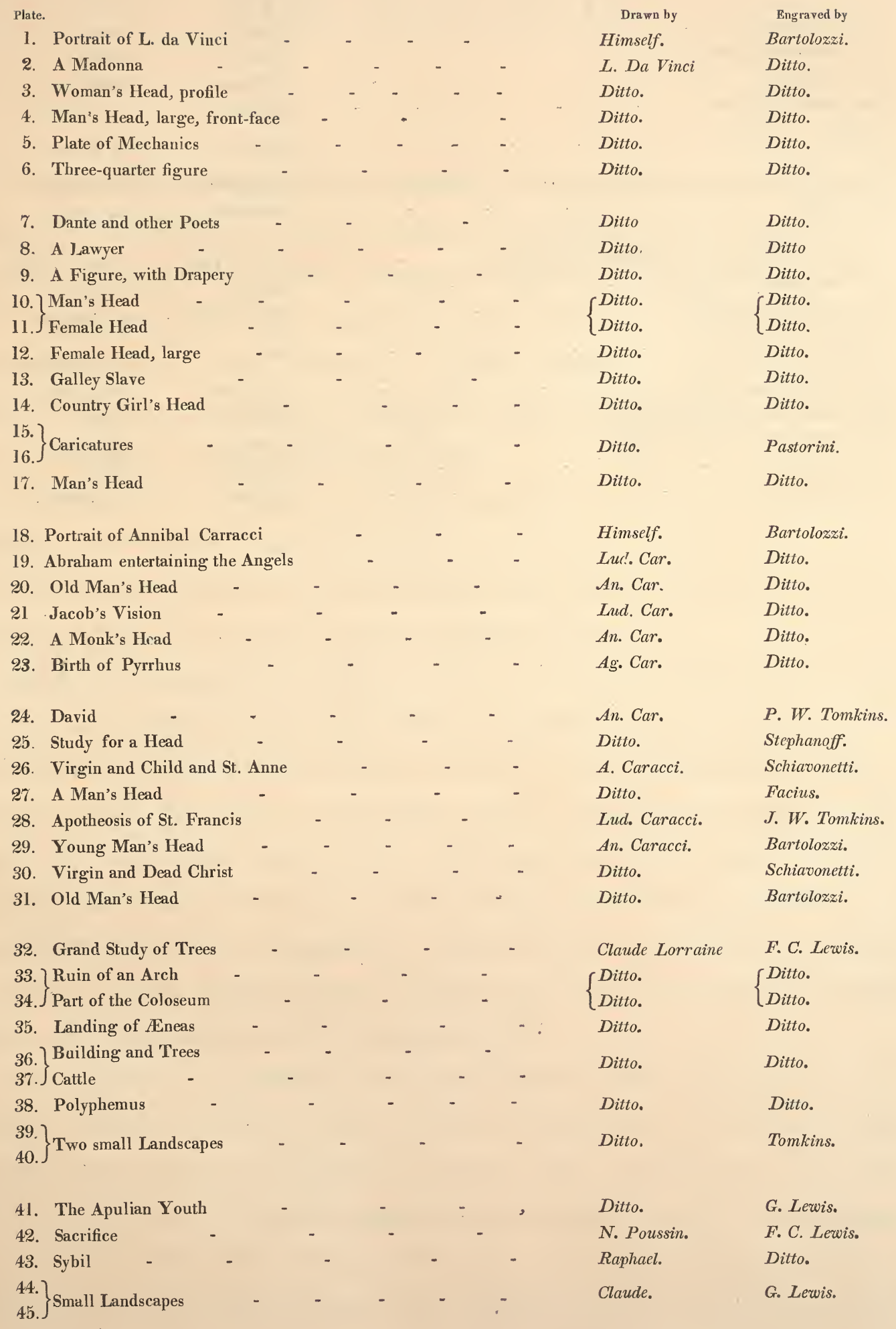


CONTENTS

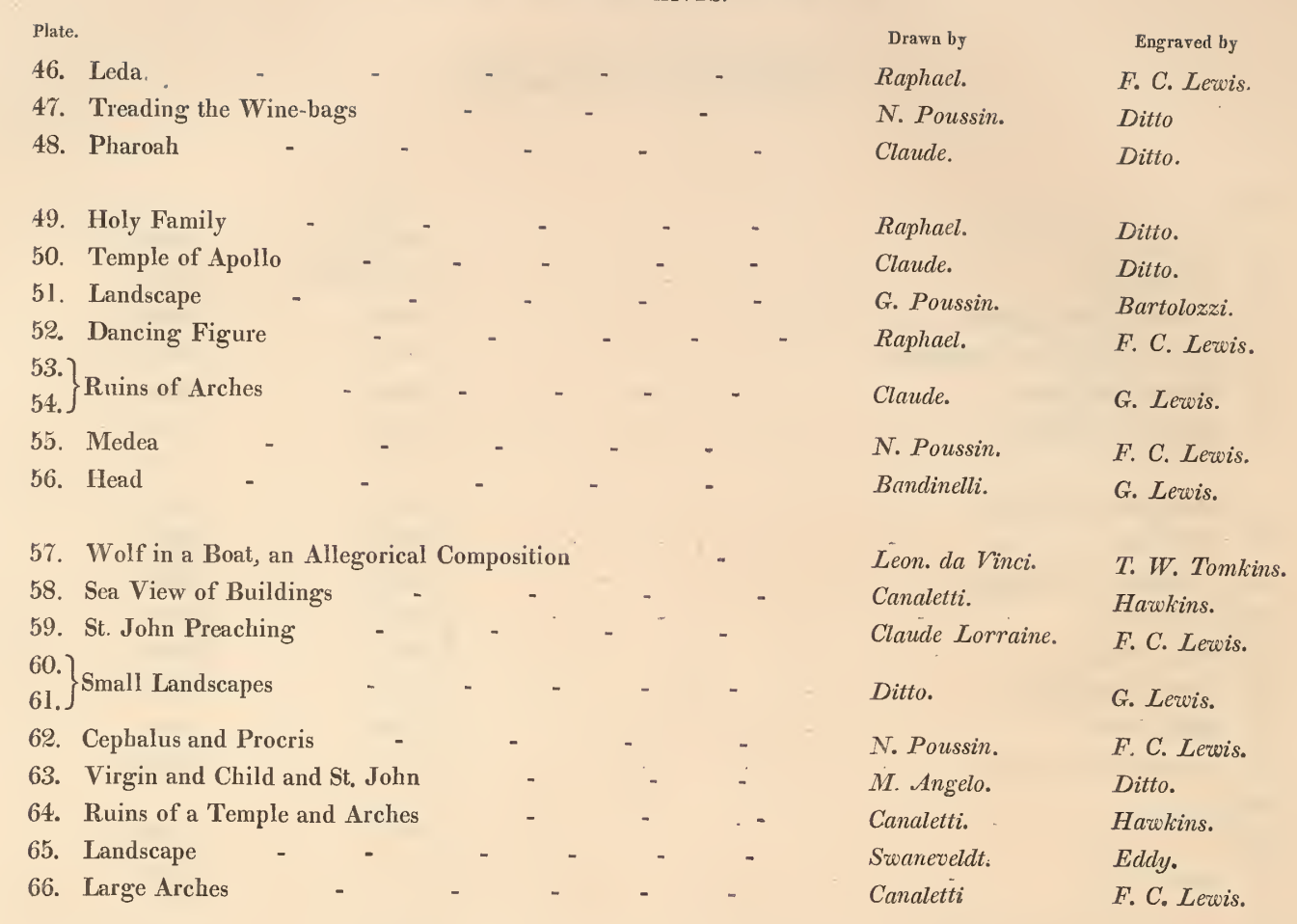




\section{THE GARAGGIS.}

To the Caraccis, but to Annibal particularly, biography has done such ample justice, that any additional account of their lives, might seem to be unnecessary; and indeed the purpose of the subsequent sketch is rather to abridge, than to add to what has been written: to collect and combine some of the most prominent parts of the Caraccis' character; to take a slight view of the progress of their art; to trace them from the imperfect essays of their youth, to the vigorous and matured labours of their manhood.

The lives of the Caraccis are full of instructive lessons, that stimulate to industry; that inspire hope; that prepare the student to expect, and fit him for encountering difficulties; that teach him, that activity of effort, and perseverance in pursuit, are seldom exerted without success.

Annibal and Augustin Caracci were the sons of tailors; Ludovico was their cousin. At a very early age they evinced a propensity to the art, in which they afterwards attained such eminence. Of the genius of Annibal, the following early proof was given:- - His father, Antonio, whose poverty had obliged him to sell a small farm, was, on his return from Cremona to Bologna with his son Annibal, robbed of the money which he had received for his property. He immediately applied to a magistrate; and Annibal drew with such accuracy the faces and forms of the robbers, that they were instantly recognized by the officers of justice, and the money was recovered.

Before the Caraccis arrived at the age of manhood, they displayed such excellence, that they excited the envy of their contemporaries. The envy of their contemporaries, however, produced in them only a wish to proceed in their studies; yet, to avoid the public prejudice which had been raised against them, they retired a while from their native country; and making their absence profitable to their art, they travelled to those places celebrated for the possession 
of the masterworks of painting. They applied with the utmost diligence to improve themselves in their art; they studied nature; they drew after casts; they contemplated with enthusiasm, and they copied with correctness, the works of Titian, Correggio, and Paul Veronese; and they acquired a vigour and truth of outline, a force and harmony of colouring, and a facility of execution, that entitled them to general applause.

But their style, so different from that of their contemporaries, made but tardy progress. They were described and decried by their opponents, as rash innovators; their genius lingered without encouragement, their diligence was exerted without reward. Upon the minds of the Caraccis, this neglect made different impressions. The mildness and timidity of Augustin pined under it; the firm and vigorous mind of Annibal repaid it all with scorn and contempt. "I wish," said Augustin to Ludovico, "that in this our new style, we may not be mistaken. The public taste is with our opponents. To oppose the current is always rash, and is sometimes unsafe." Ludovico recommended patience. "Fear not," exclaimed Annibal, with energy; "let us go on. Columbus was treated as an idiot, when he suggested the probability of discovering a new world. The works of Titian and Correggio are now held in universal admiration: we walk in the same path, and shall at length attain the object of our wishes." The encouraging speech of Annibal revived the drooping spirits of Augustin. Their diligence acquired new vigour; they resolved to persevere; and they continued their studies with the utmost assiduity.

The style of Augustin was at first more fertile and more elegant than that of Annibal: the former possessed more chastity, the latter more luxuriance. The drawings of the one, were the correct efforts of judgment; the designs of the other, were the careless effusions of genius. Annibal saw his errors, and corrected them. It was usual with them to submit their pictures to each other's criticism. The severity of the critic, was not moderated by the tenderness of the brother; faults were neither palliated nor concealed; and mutual improvement was the result of this rigorous investigation.

To extend the knowledge of their works, they opened an academy, in which they taught not only after the best formed living subjects, but after exquisite 
casts and heads of antique statues; and they studied anatomy, and they examined under the ablest masters, as Leonardo da Vinci had done before, the bones and muscles of anatomical subjects."

The manner in which they conveyed their instructions was so excellent, that Guido and Albani urged the impossibility of not improving in the school of the Caraccis, "under whom studying was an amusement, and learning a diversion."

Annibal and Augustin afforded a rare example of perseverance and correctness; the drawings for their great works were executed with the utmost care; they made separate sketches of the various parts, and they repeated them until they had overcome every difficulty; they would then, from the different designs, form a correct and perfect whole. The larger part of the drawings, from which engravings are now published, were done by Annibal, Augustin, and Ludovico, for their great works.

The principal object, indeed, intended by the publishing of these engravings, is to facilitate to the Artist the means of study and improvement. The works of the great Masters swell the collections of the curious, but are of little general use. Access is rarely permitted; and when permitted, affords but few and partial advantages to the student. He is indulged only with a short and transient view of excellencies, which require to be examined with the nicest care, and to be studied with the deepest attention. He, therefore, who multiplies engravings from the works of the great Masters, renders no mean service to the art.

The academy of the Caraccis acquired a high degree of celebrity. The public opinion, which at first characterized their style only as new, now allowed that it was natural. The stiff and cold manner of their opponents, was no longer supported by prejudice; the force of truth prevailed; and the genius and science of the Caraccis were universally encouraged and adequately rewarded. They were now employed in many great works.

In the year 1600, Cadinal Farnese invited Ludovico to paint his gallery

* A similar mode of conduct had been adopted by Leonardo da Vinci, whose anatomical drawings are executed in a style of excellence which has not yet been surpassed. Engravings from those drawings, his Majesty has graciously permitted to be pub. lished from the original MS. volume in his Collection. 
at Rome; but Ludovico, on account of the multiplicity of his engagements declined the invitation, and recommended his cousin Annibal. Annibal was at first assisted by Augustin; but a difference in their dispositions and habits, Augustin being fond of pleasure, and Annibal being passionately devoted to his studies, occasioned their separation, and Annibal carried on and completed the great work alone.

The undertaking occupied eight years; and is finished in a style of such excellence of disposition, and such harmony of colouring, as to render it unrivalled. For a work of such rare merit, I am ashamed to relate how inadequate a recompense was bestowed; - the sum sent to him by the Cardinal, amounted to no more than five hundred gold crowns.

Annibal, who had formed a hope that those eight years of labour, would have procured him a sufficient provision for the necessities of old age, was deeply affected by the disappointment. A settled melancholy and depression of spirits seized him; his energy and activity failed him; he retired to Quatro Fontane; the clear air and retired situation of which might, it was imagined, recruit his spirits, and restore his health. The air of Quatro Fontane was so far beneficial, that he returned to Rome, and accepted an offer to paint the Life of St. Diego, in a sumptuous chapel in the church of St. Giacomo; but his strength was inadequate to the completion of the work; he was seized with an apoplectic fit. His melancholy increased; he went to Naples, the air of which is milder and purer than that of Rome; but from which, however, he received no benefit. He returned to Rome, and grew worse: his physicians, from ignorance of a disorder which a mistaken delicacy had prevented him from disclosing, treated him injudiciously, and on the 13th of July, 1609, he expired.

The Caraccis were not remarkable for any personal beauties. Annibal was careless in his dress, somewhat invidious in his disposition, not courteous in his demeanour, serious in his deportment, and solitary in his habits; he was not fond of company, and he retired always from the notice of the great. Whenever he saw Cardinal Farnese in the streets of Rome, he would avoid him, and hide himself; and if any of the nobility paid him a visit, he would escape through one door, as they entered another. 
He never forgot the lowness of his birth; and that it might be remembered by his brother, he once sent him, when he was surrounded by the nobility, a letter, in which was inclosed a drawing of their father and mother, in the act of exercising their trade as tailors.

Augustin was of a very different disposition: he was polished in his manners, and elegant in his dress. His lectures were delivered with great clearness, and his style was so eloquent, that it excited the envy of his brother.

In one of his lectures upon the Laocoon, he dwelt with such animation upon the beauties of the statue, that the whole audience were warmed into admiration and applause. Annibal alone remained silent, and seemingly inattentive; at length he started from his seat, and drew upon the wall with great correctness, and from memory, the admirable statue. "Some painters, you see," addressing himself to his brother with a sneer, "can speak with their hands!"’

Ludovico was dignified in his aspect, and serious in his manners, though not severe. He was warm in his attachments, and patient and persevering in his temper; his style was scientific and classical, and the Bolognese preferred him to either of his cousins; but this preference was surely not the effect of judgment. Annibal was more original in invention, and more vigorous in execution; and Augustin was perhaps more chaste in conception, and more correct in finishing. 




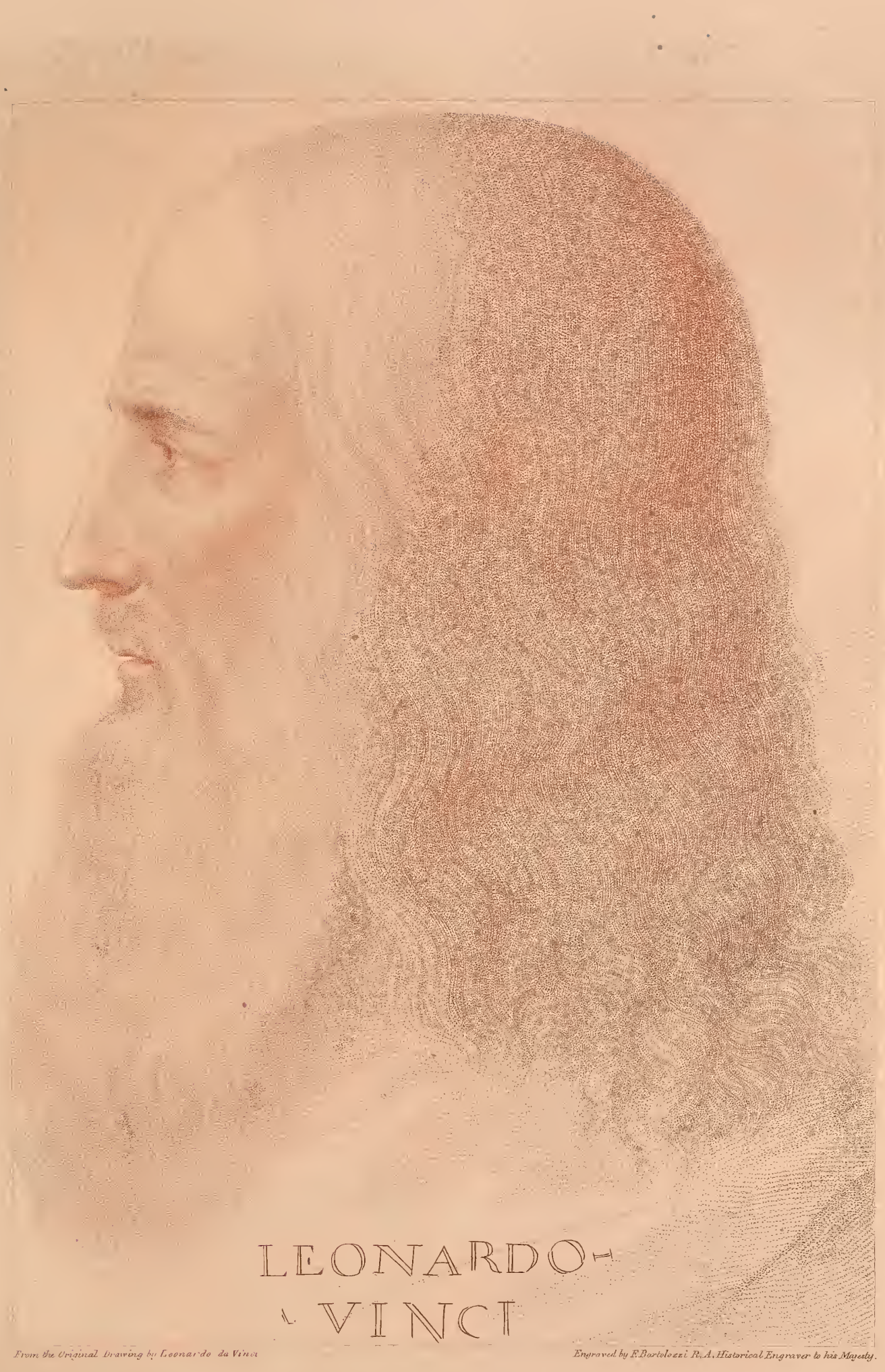

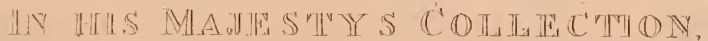


$\lambda$ 



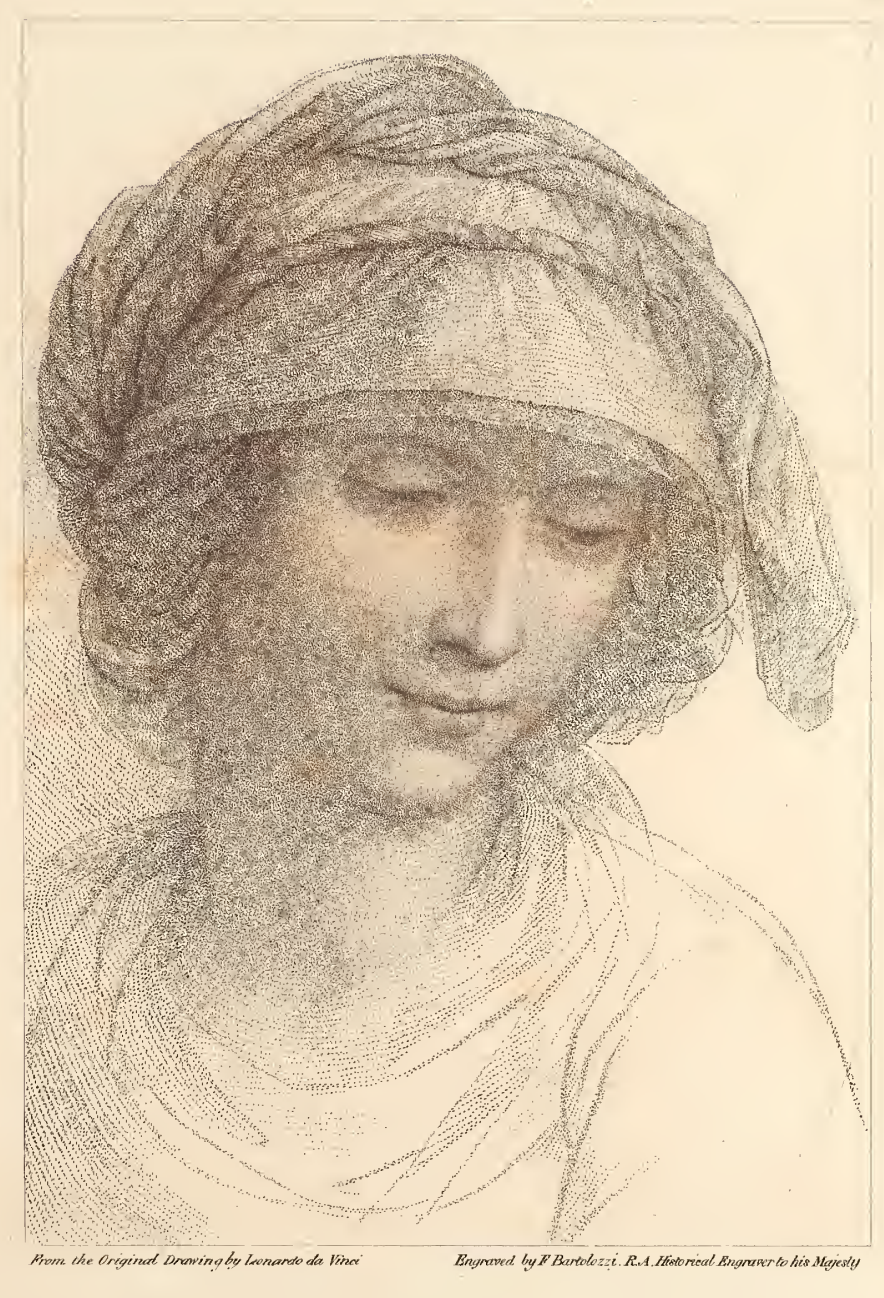

1. Publestud Ox:\%, 1796 by 1 Chamberlaine. Bromplon Row Middlesex 





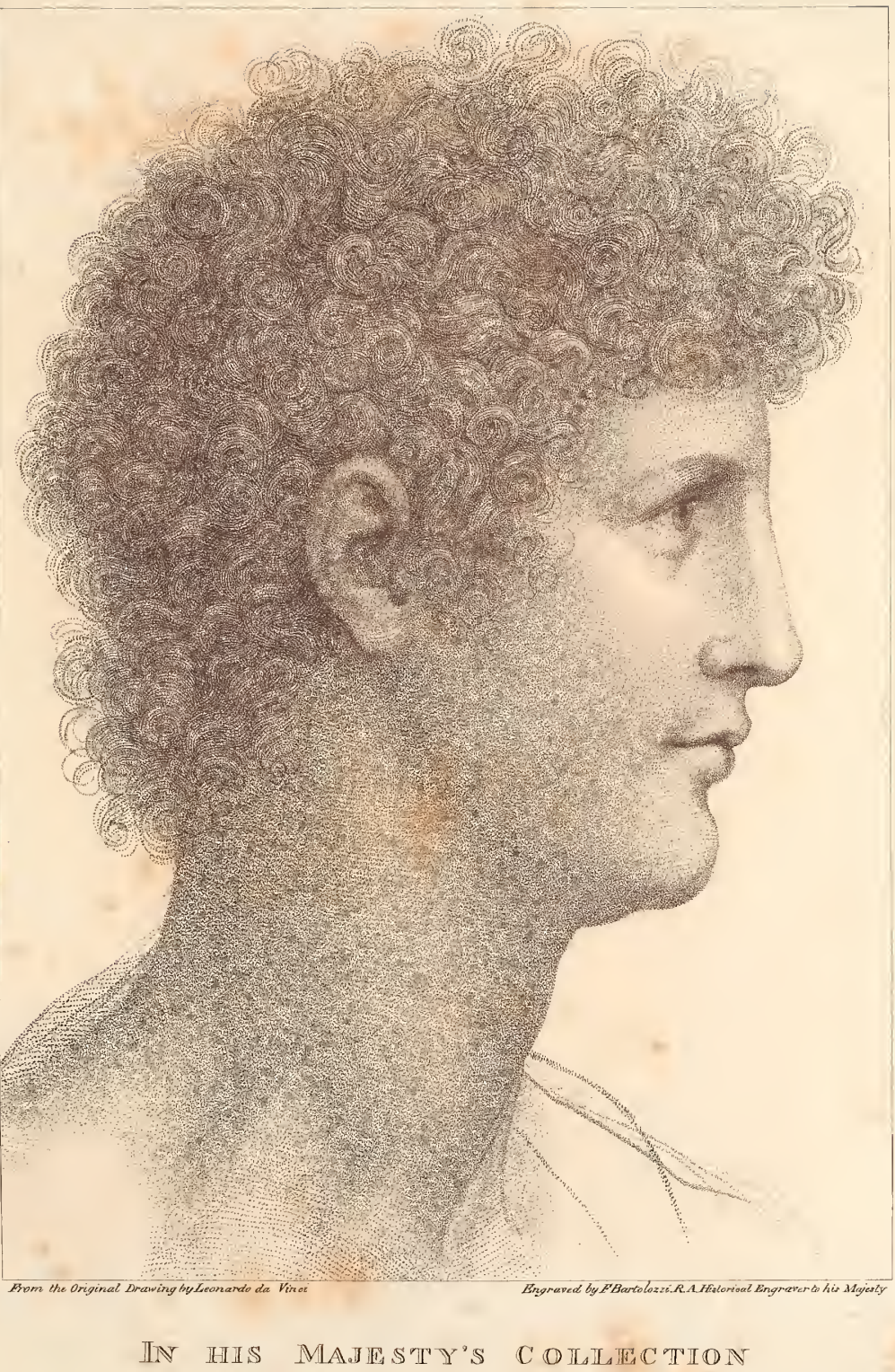

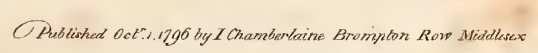






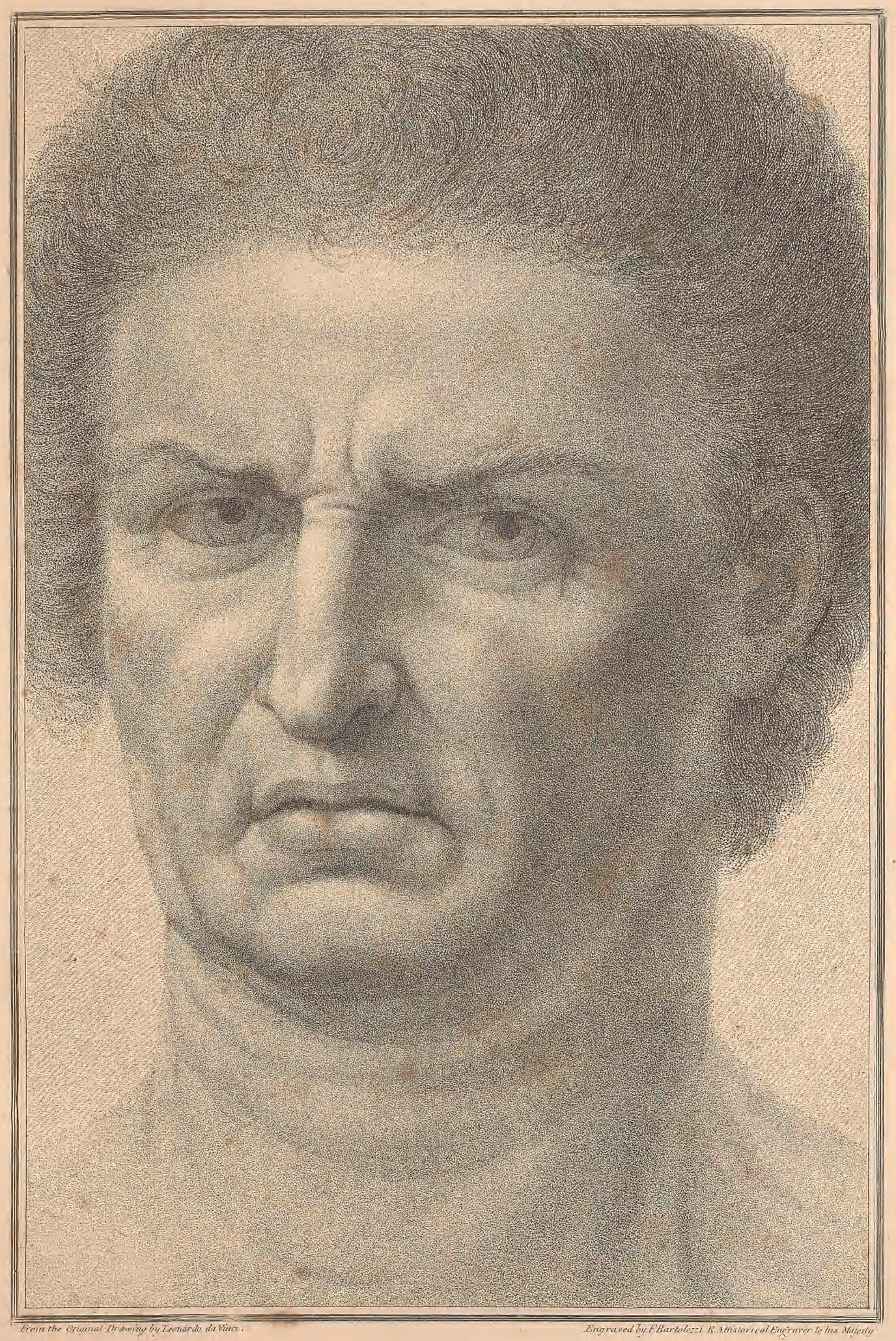

IN HISS MANESTY'S COHLTETTON

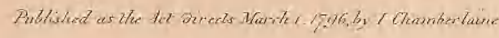







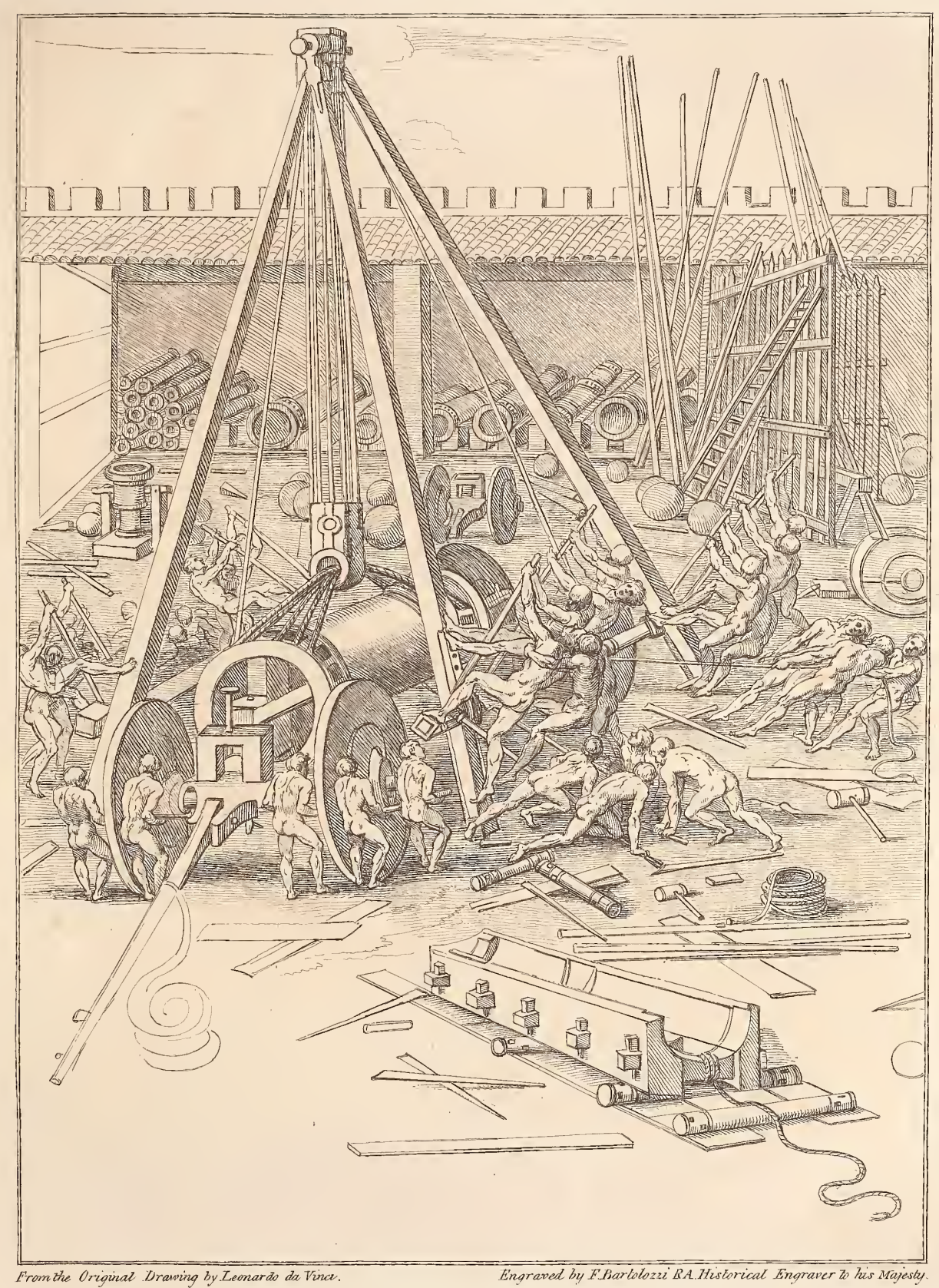

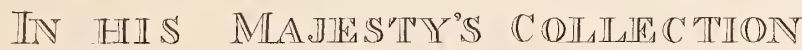

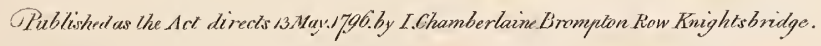







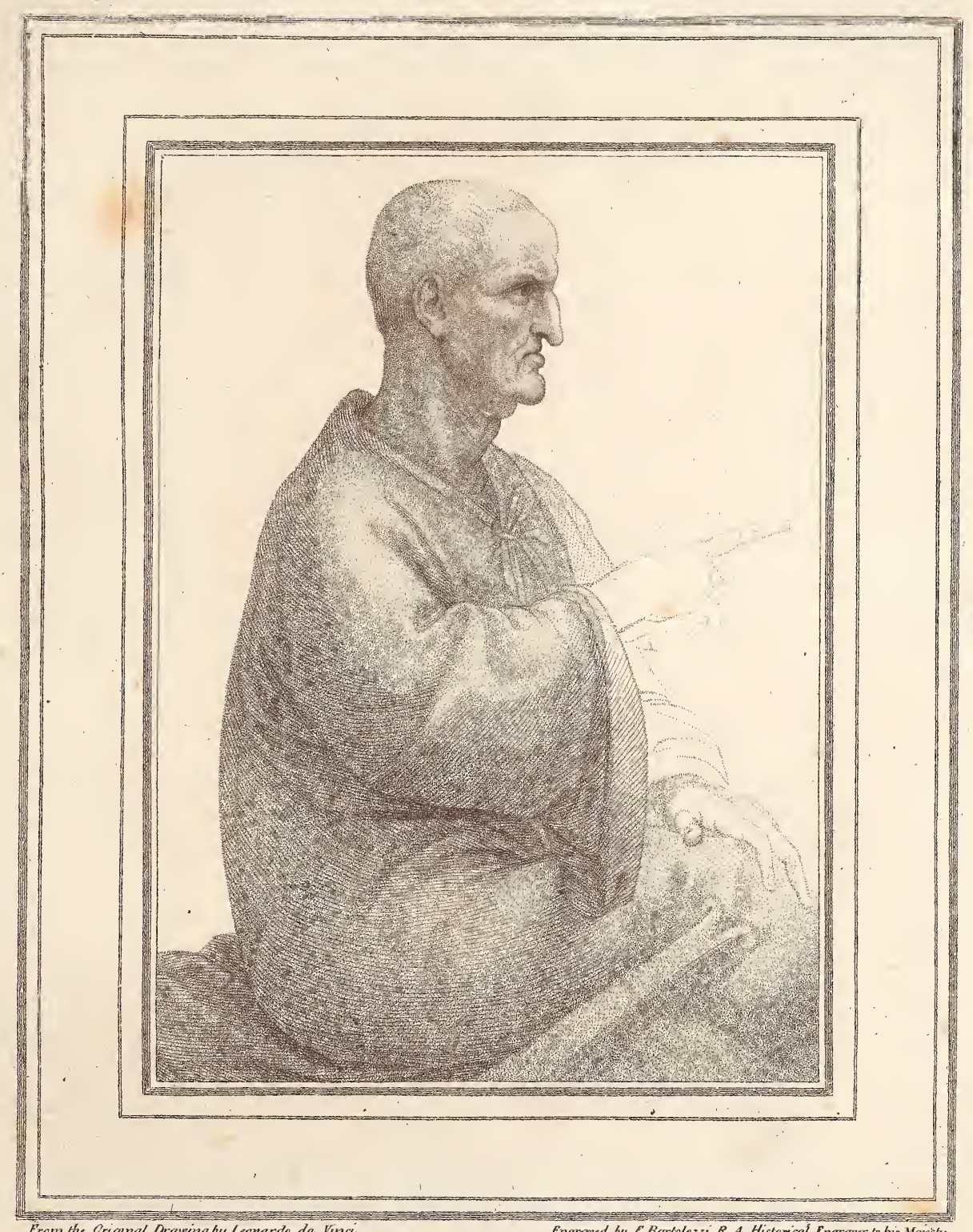

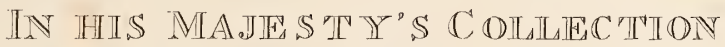

Published as the Ade directs Ap' 171796 by IChamberlaine 
$x^{2}+y^{3}+3$

+. 




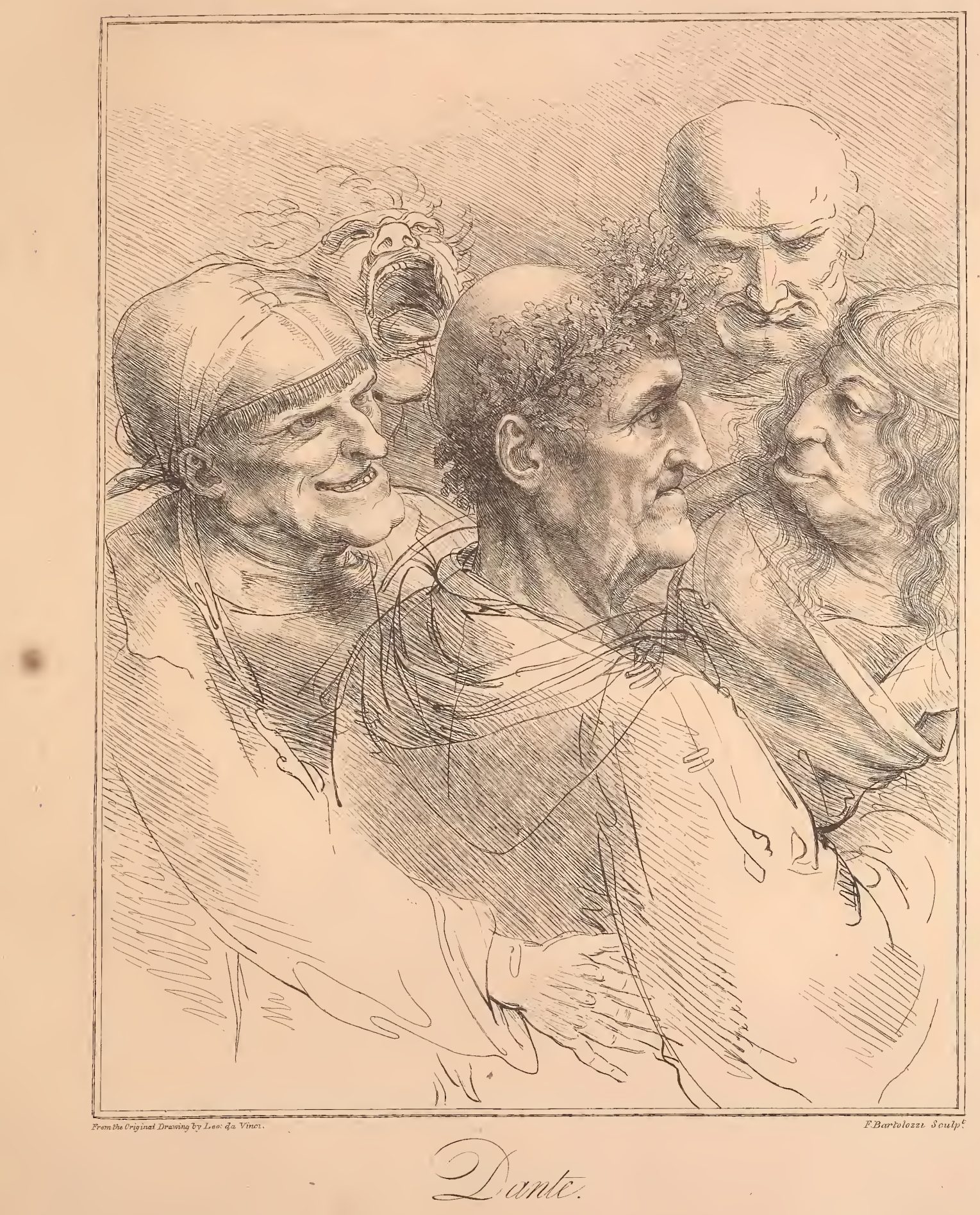

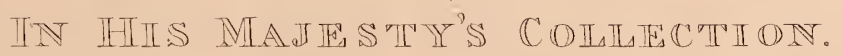




PL.TIH

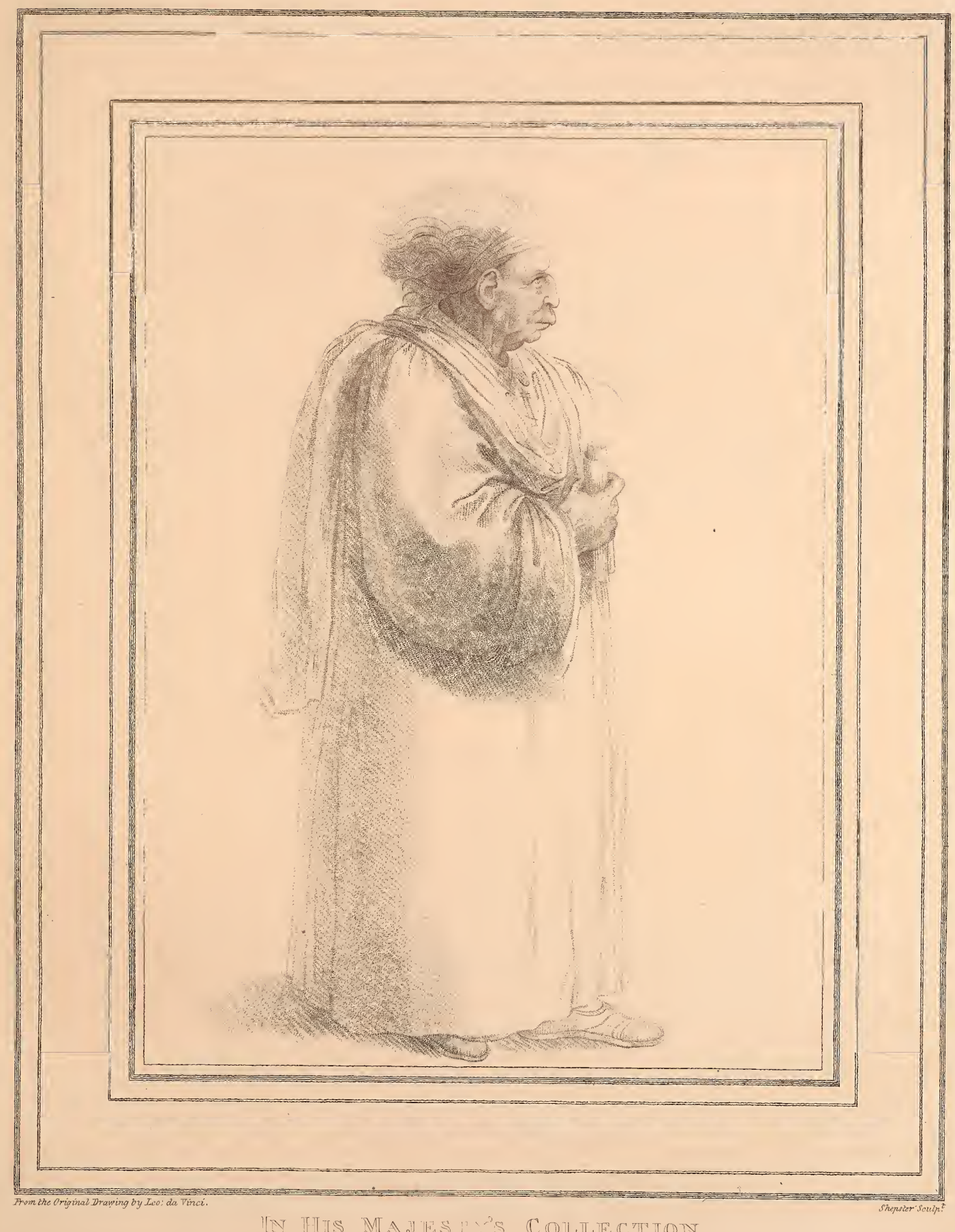

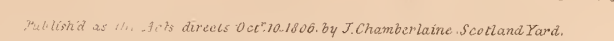







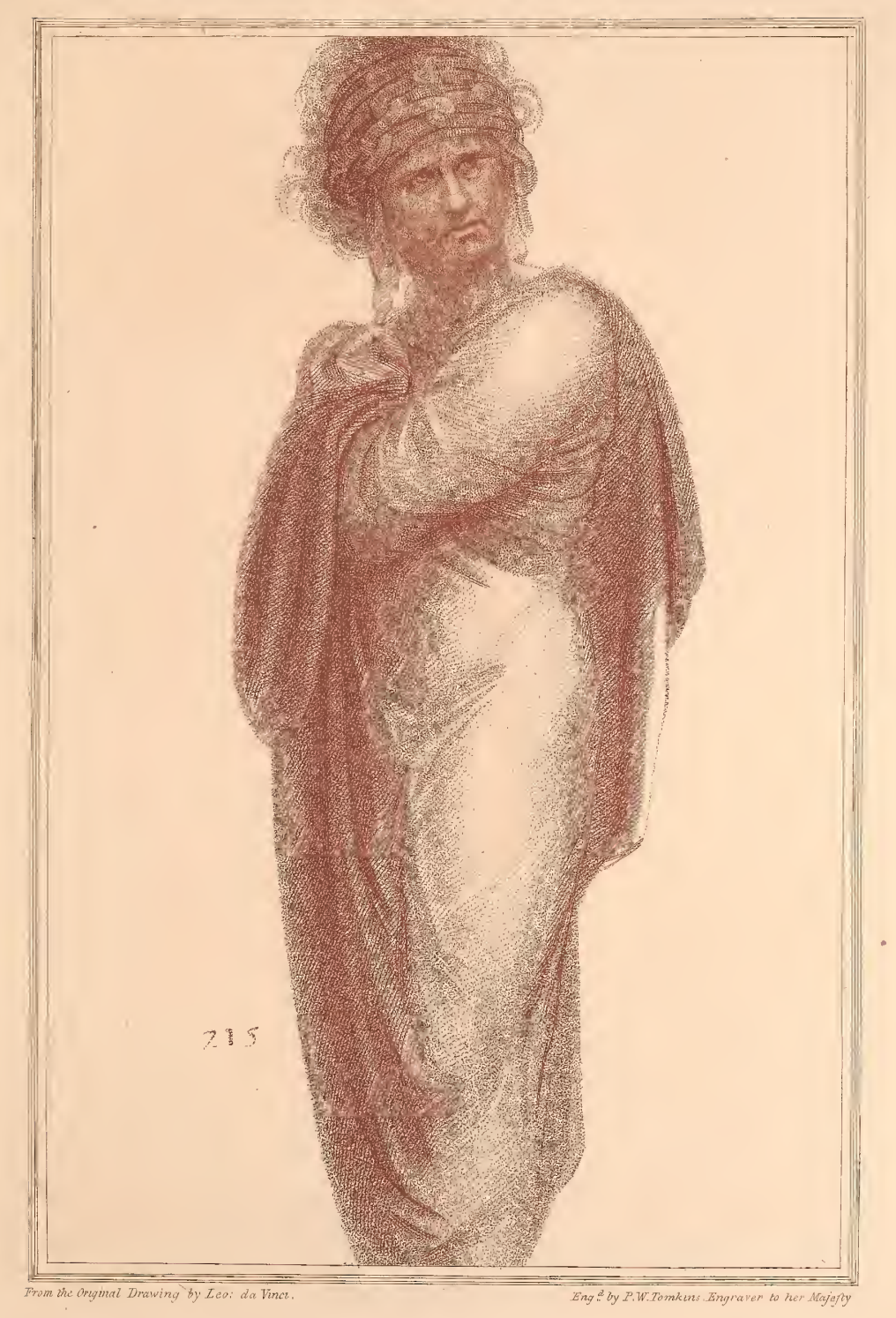

INY HIS MAJTSSTY'S COLAECTIDN. 




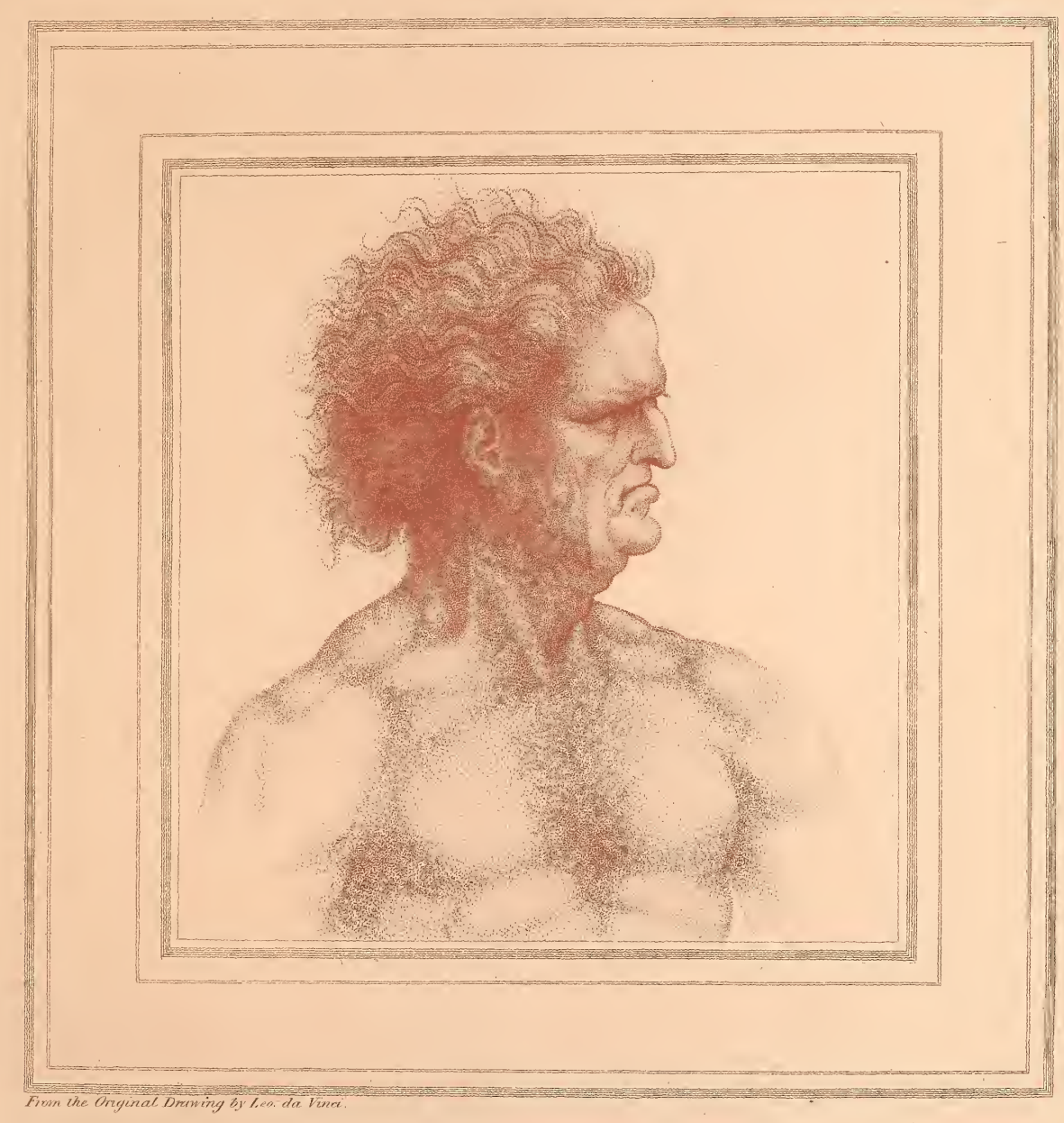

IN IHIS MAJESTTY'S COHIAETTION

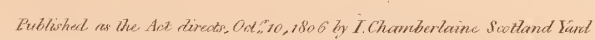






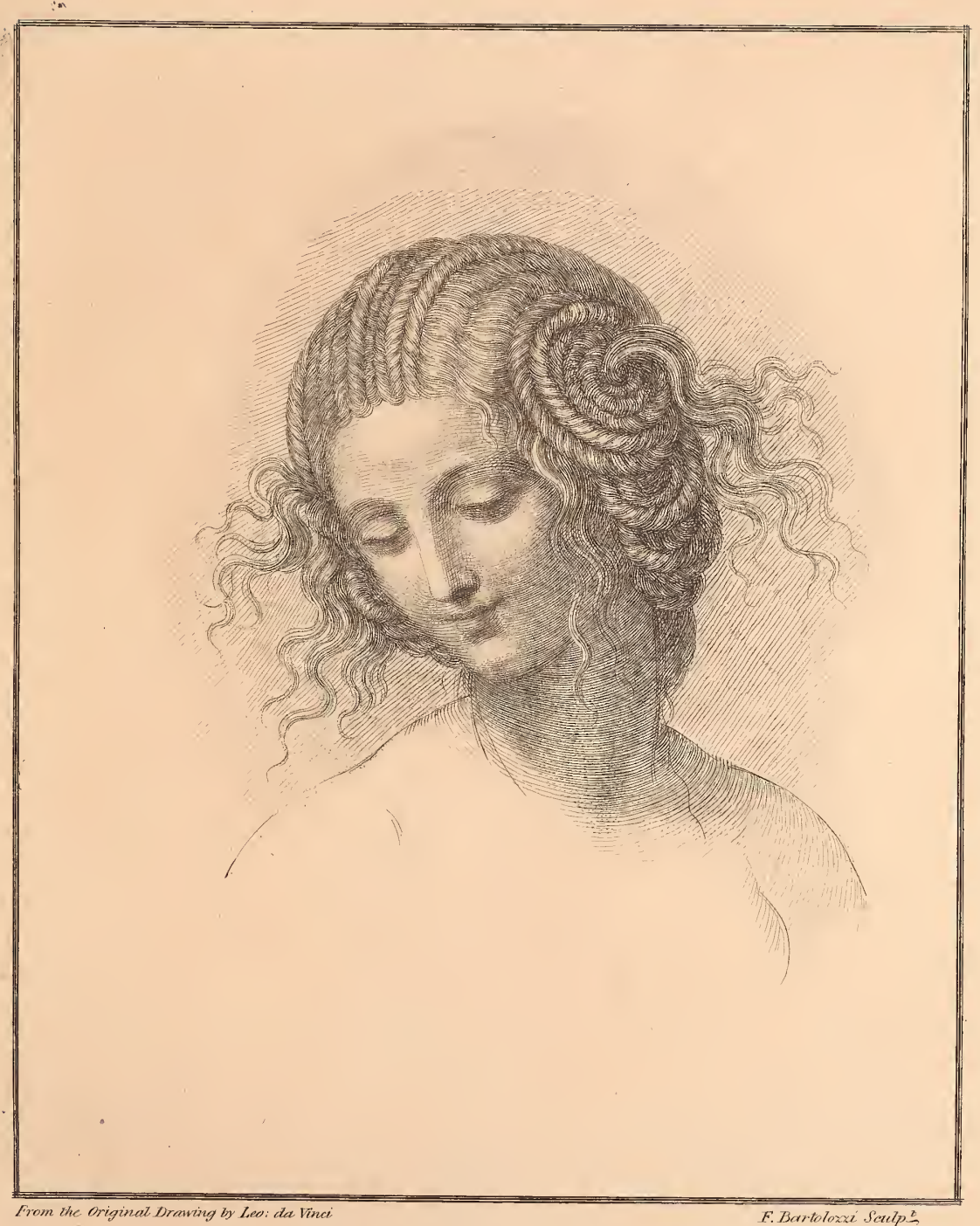

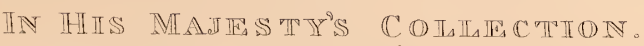

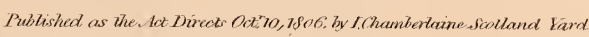







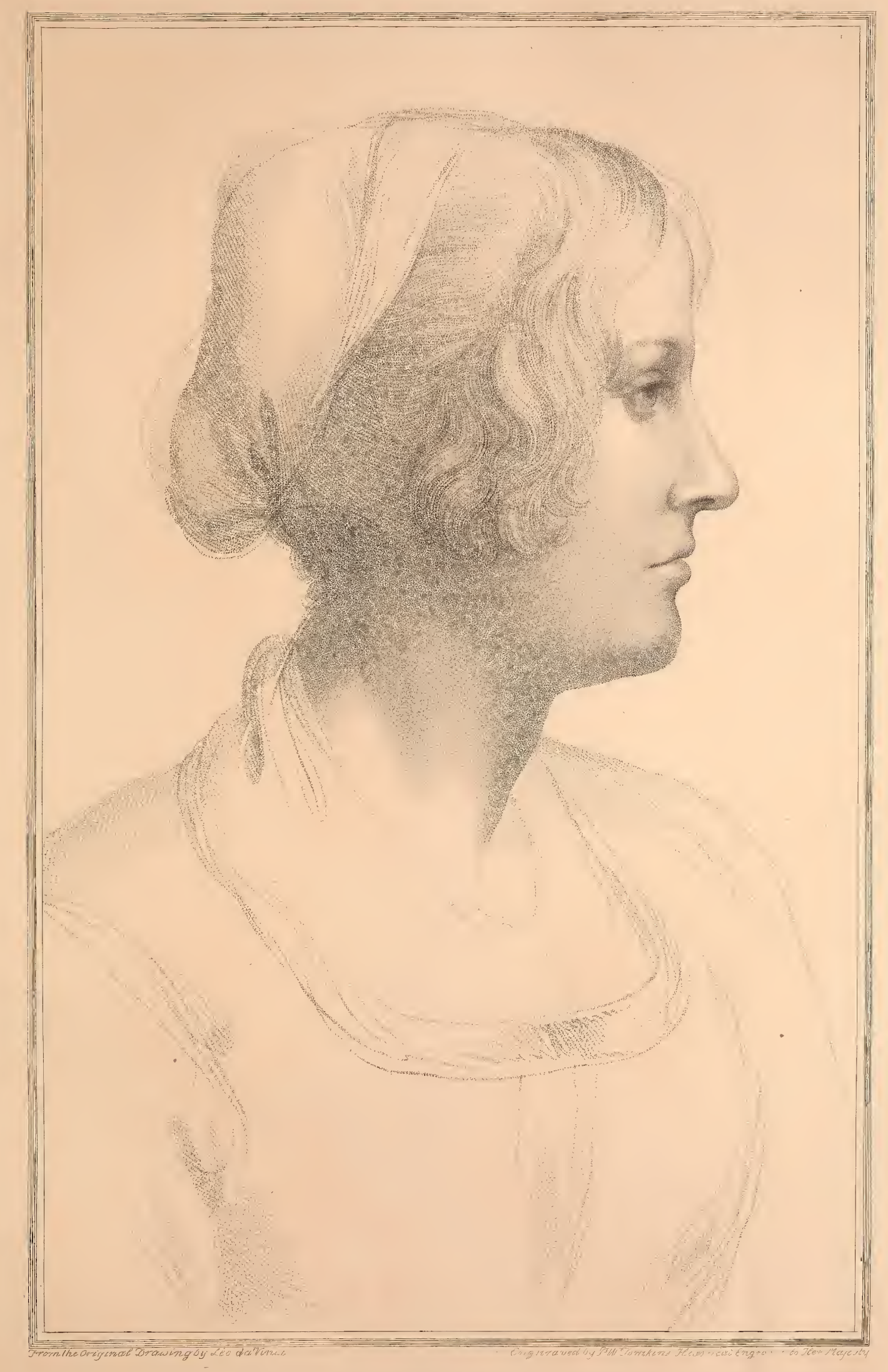

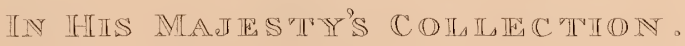






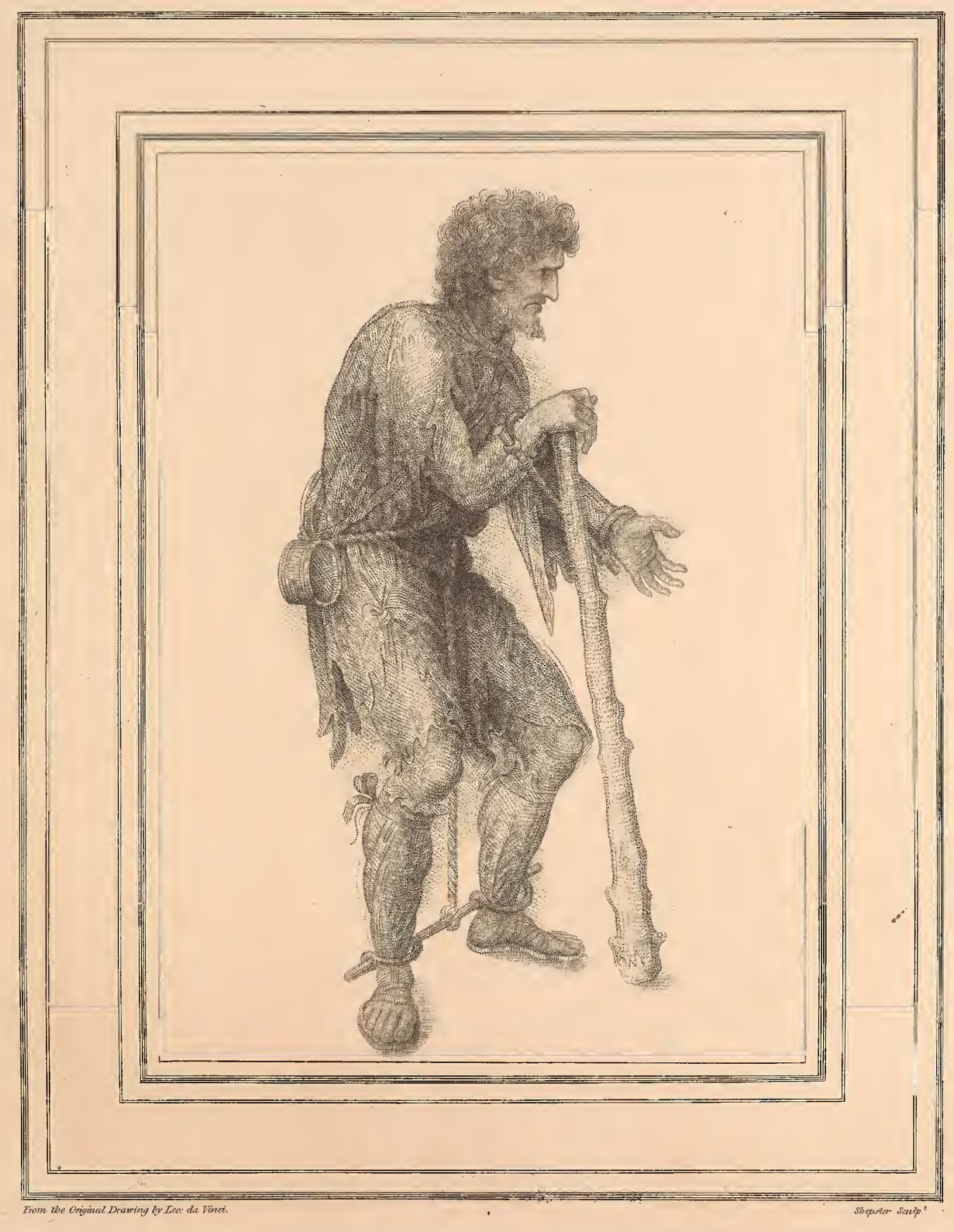

IIN HIIS MAJISTTY'S COHIECTIION。

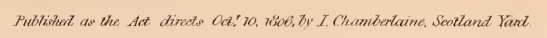






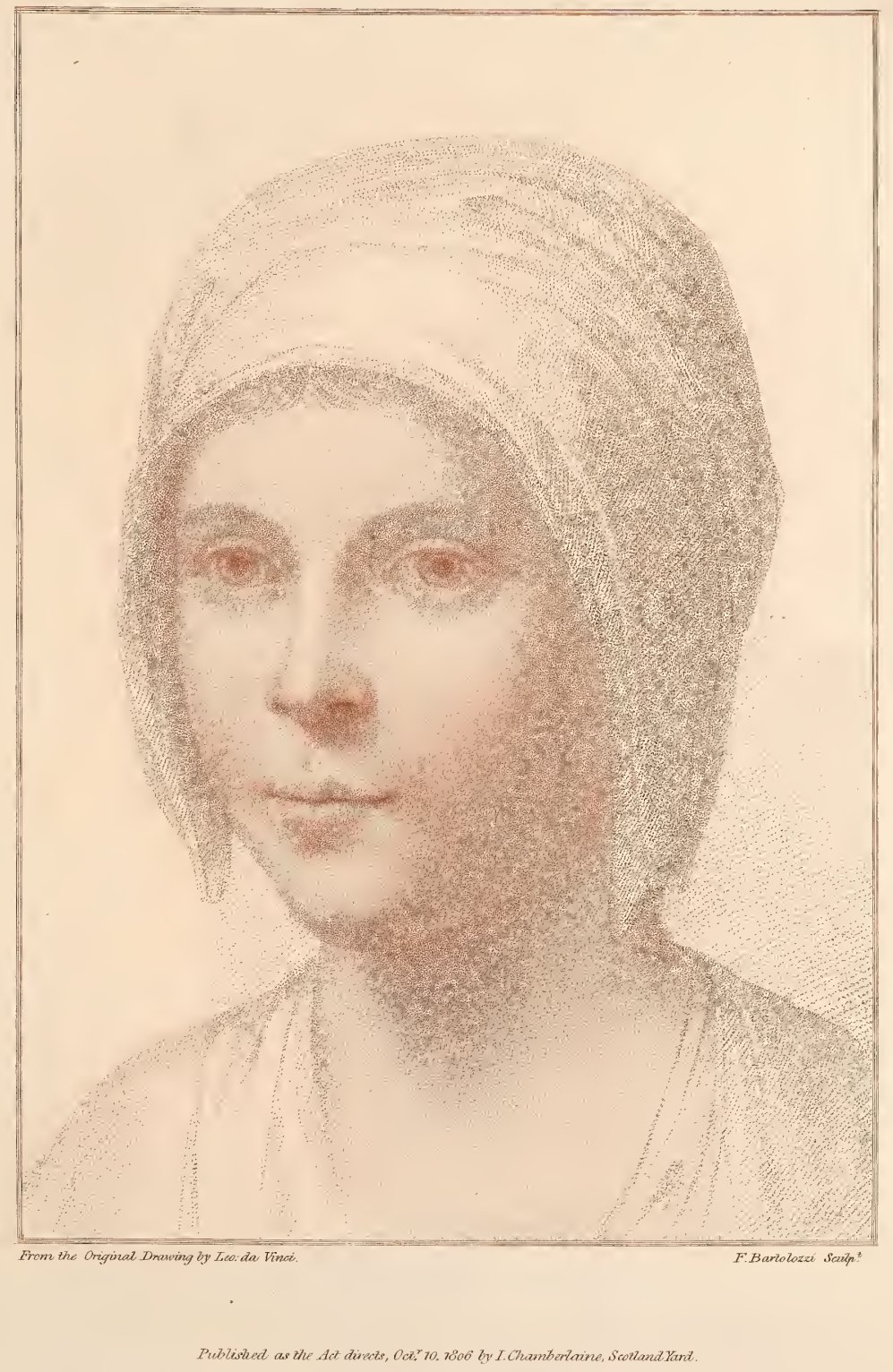




\section{,}






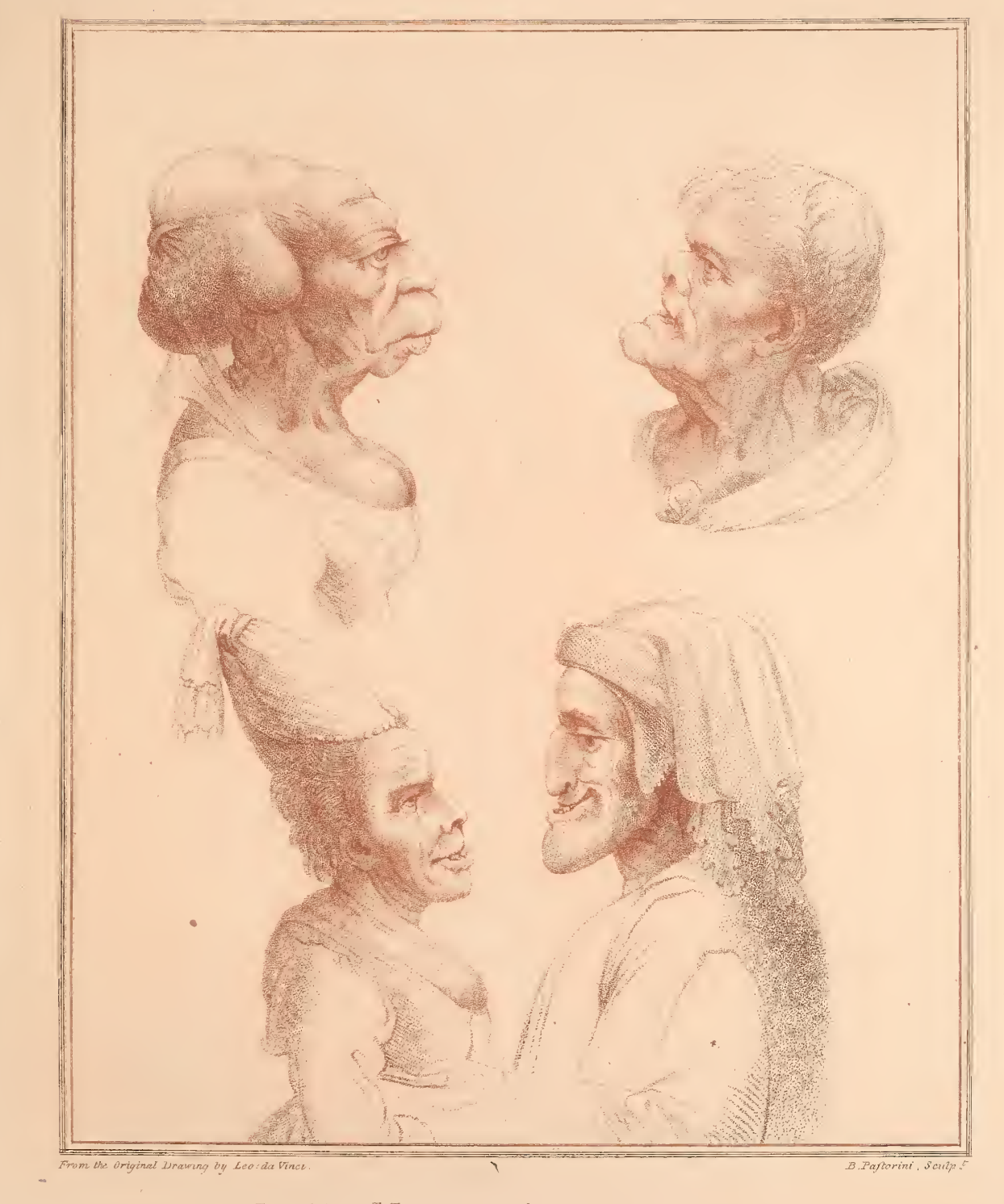

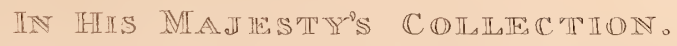






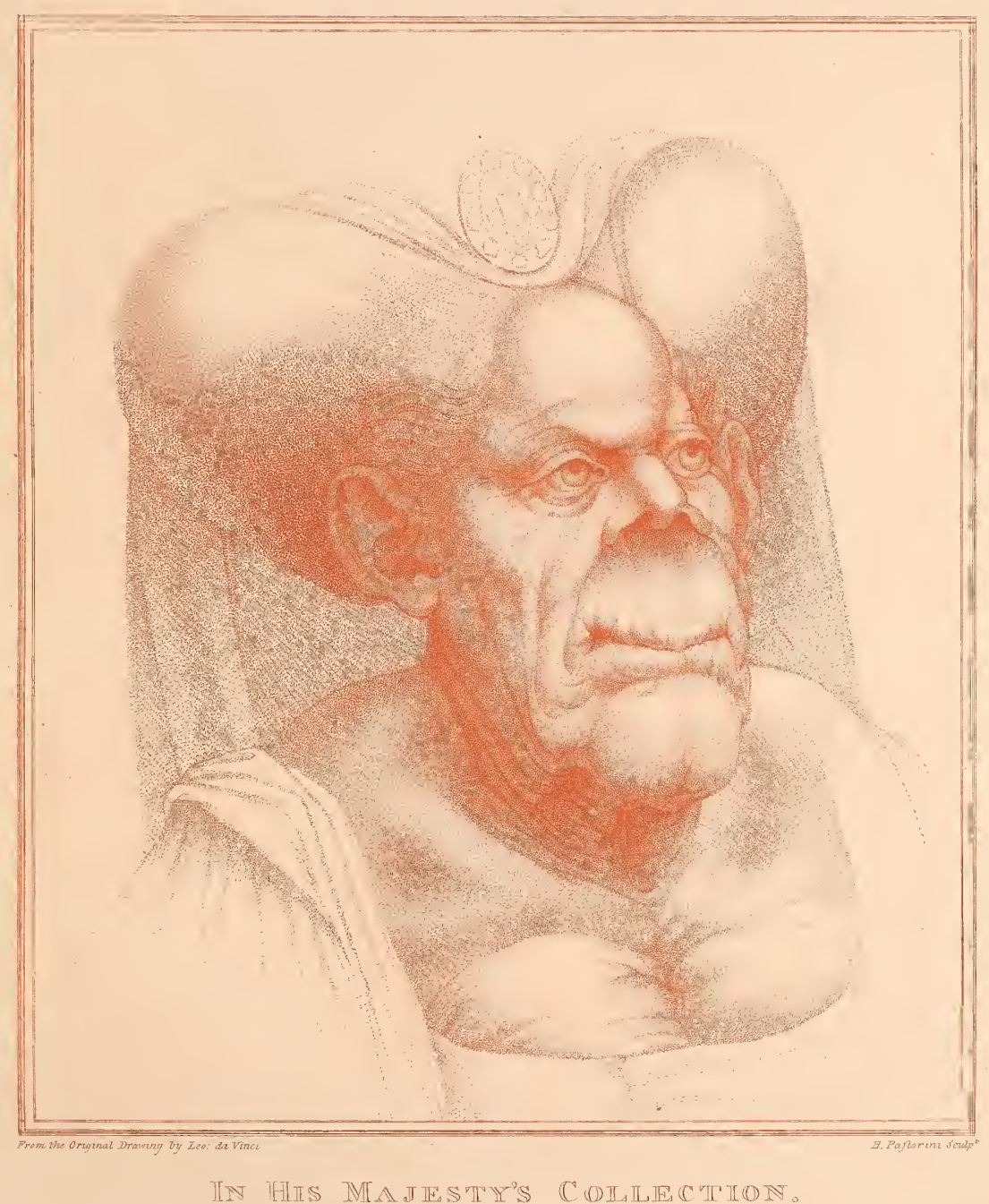

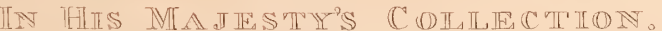




HJ. XTt

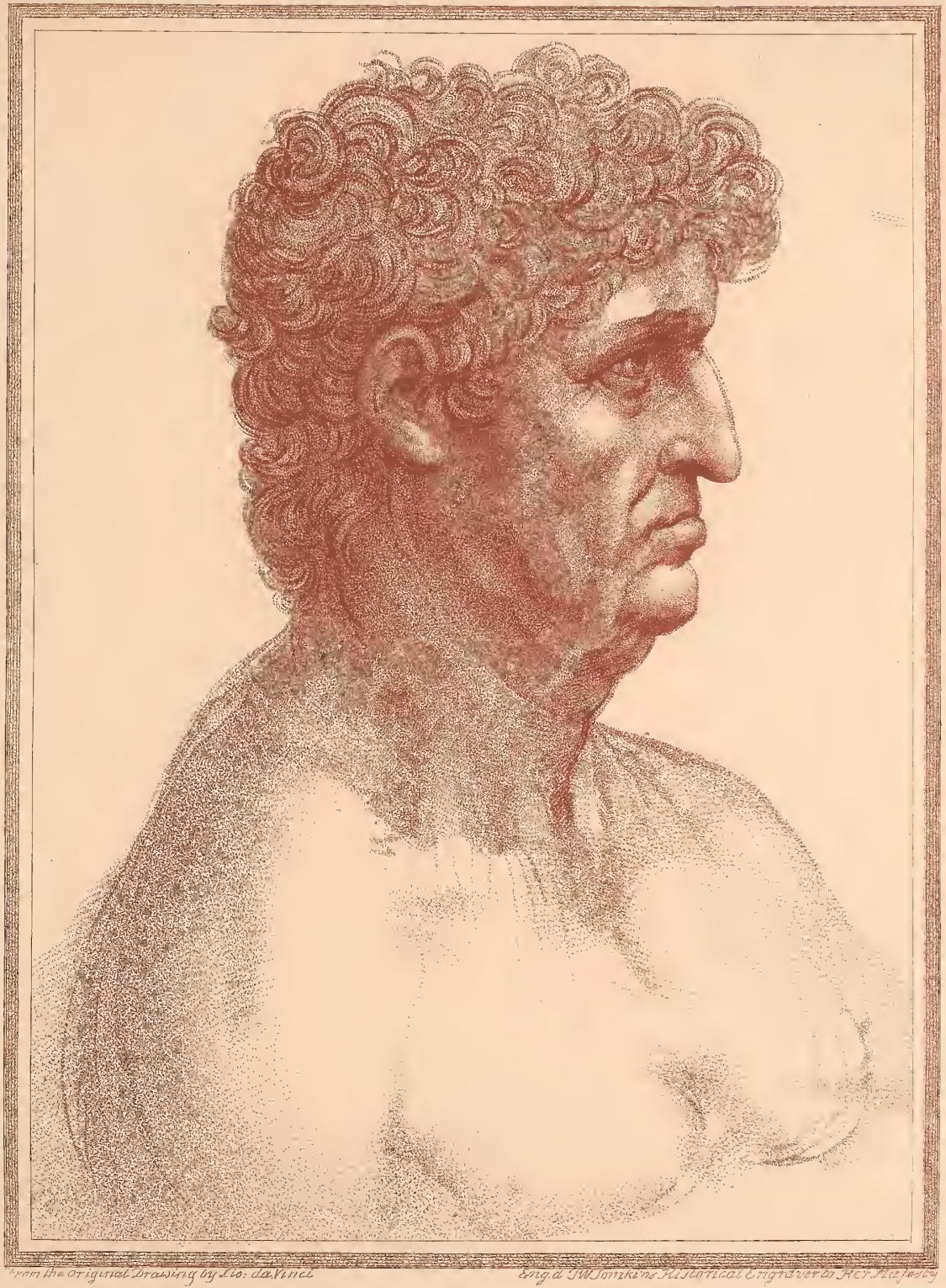

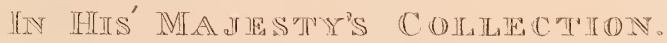






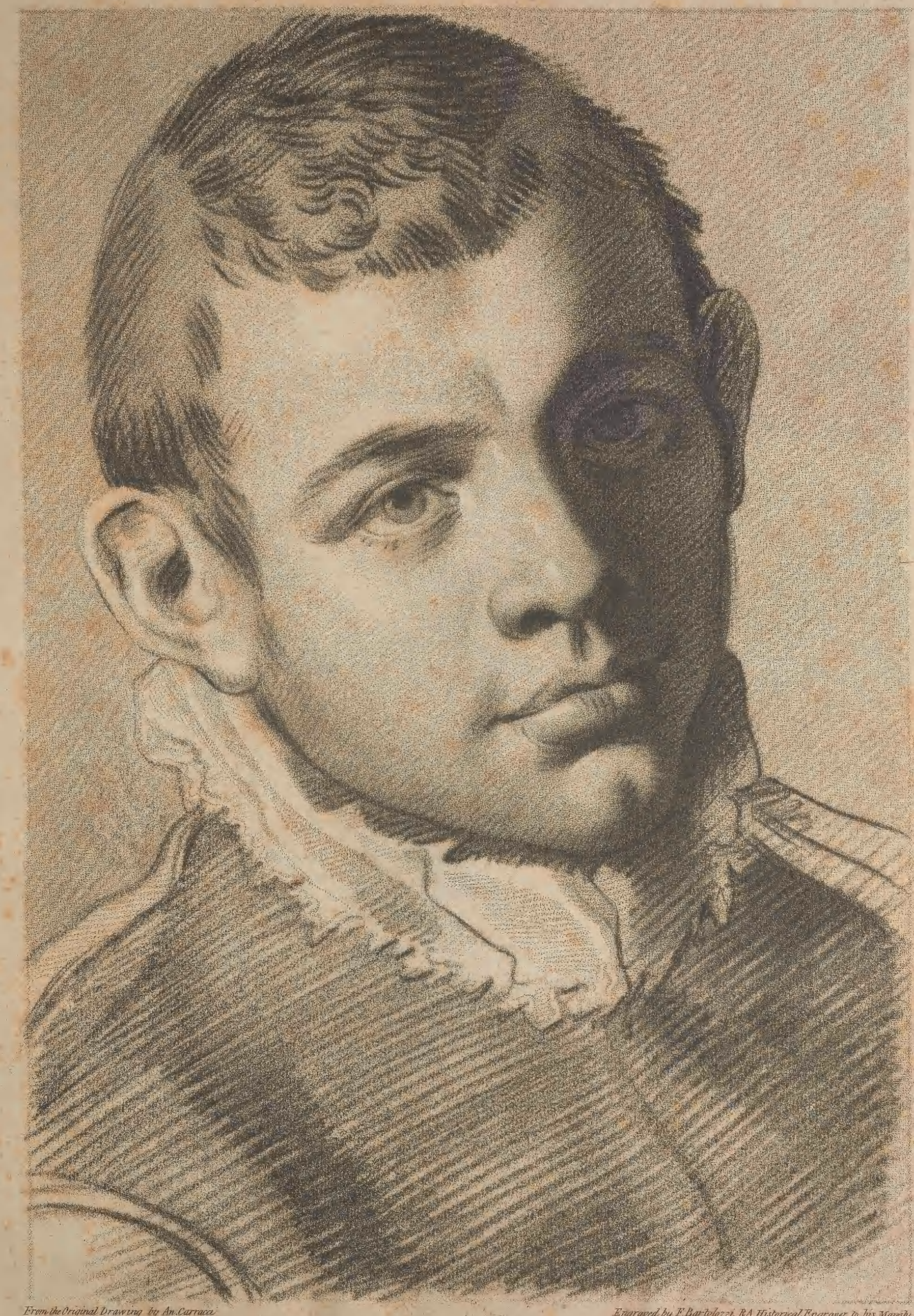

IIN HIS MANESTYYS COILTACTION. 




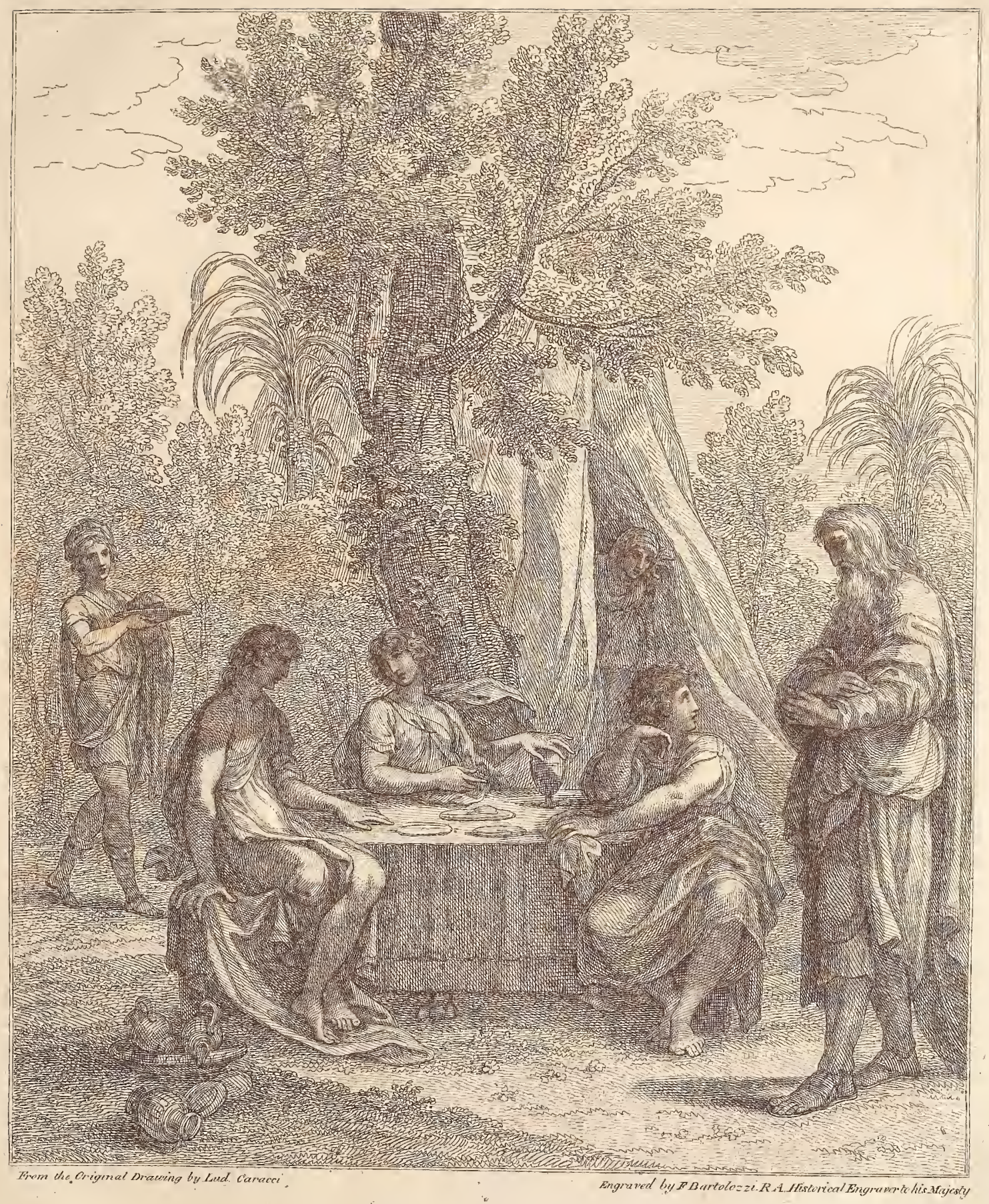






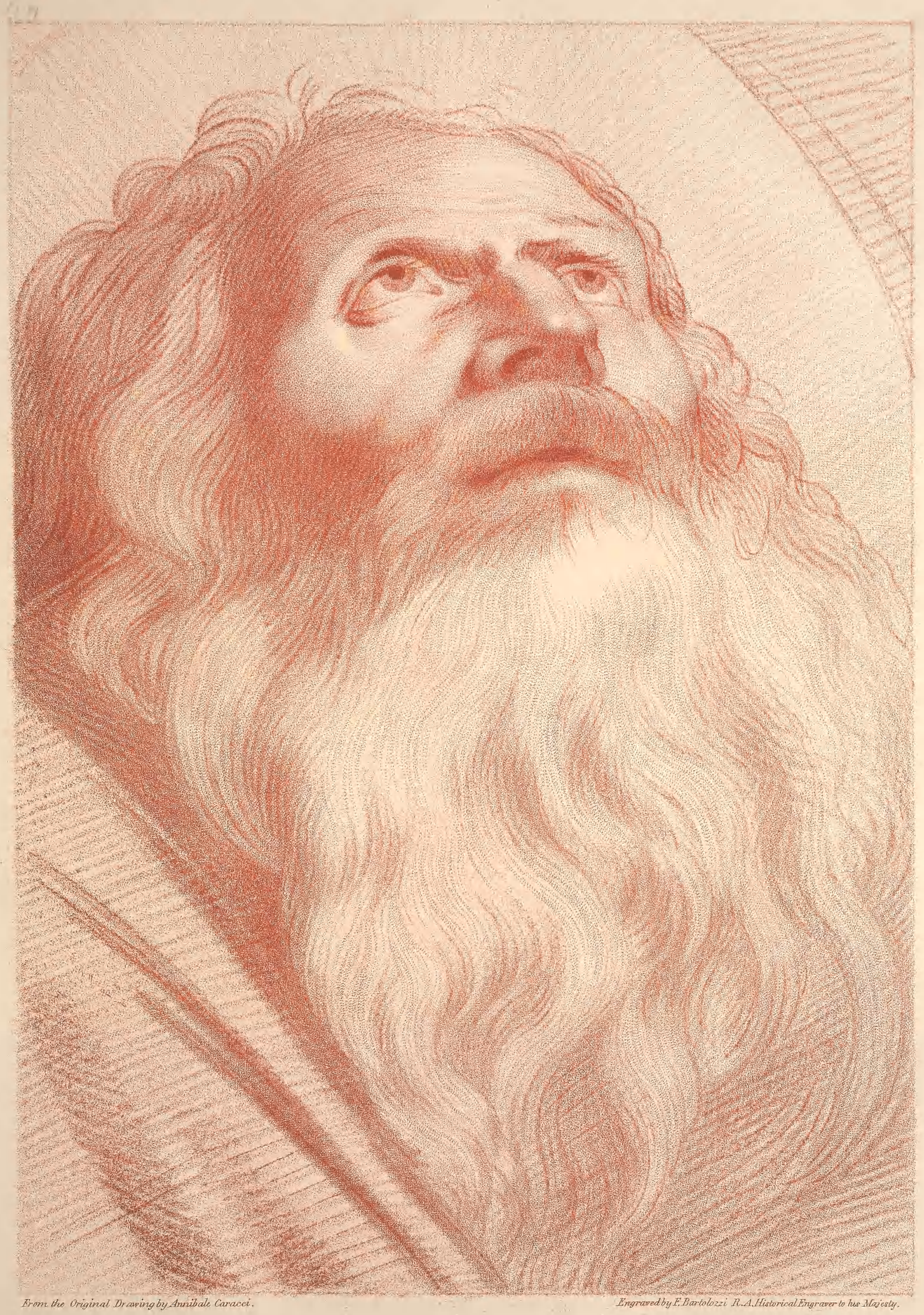







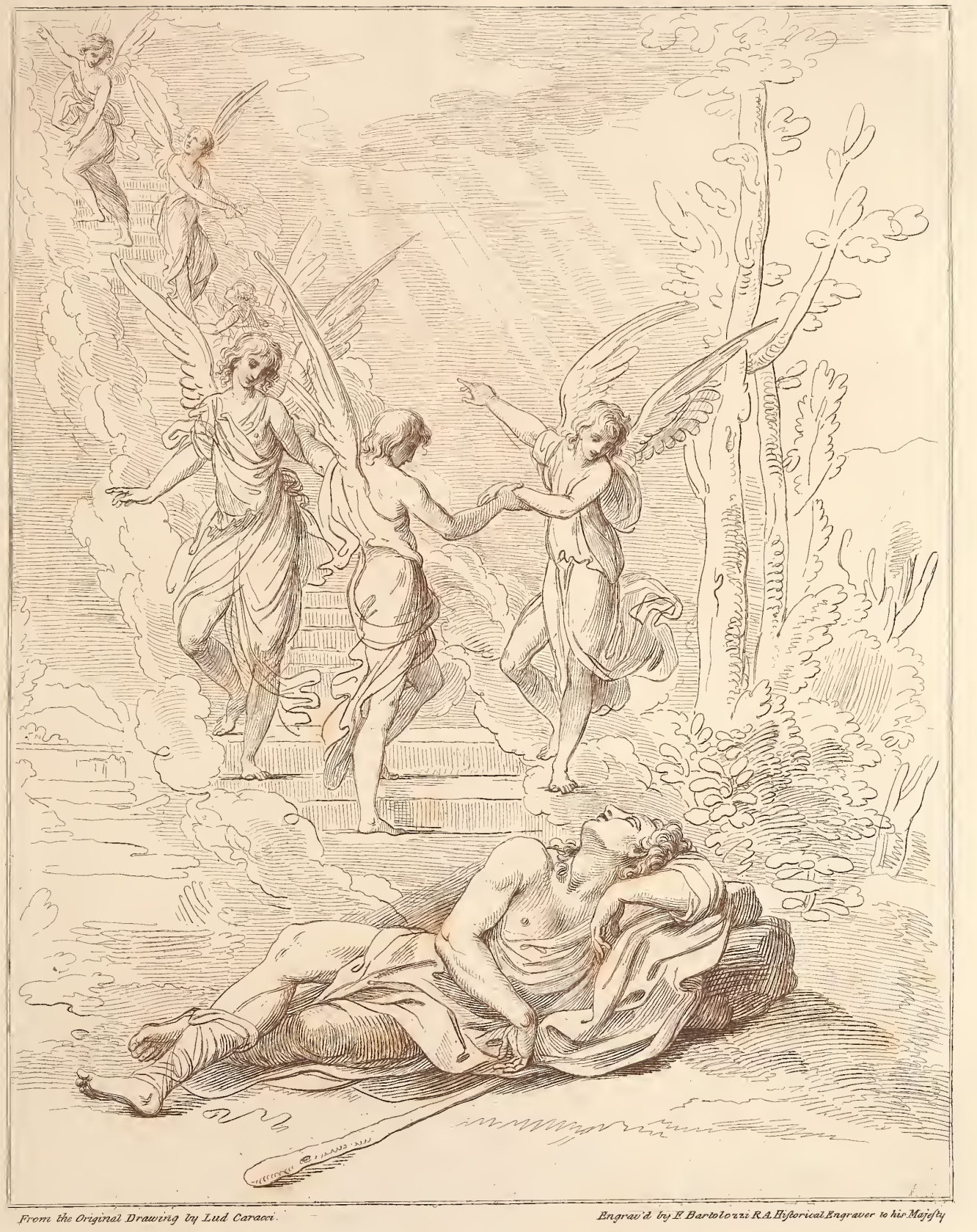







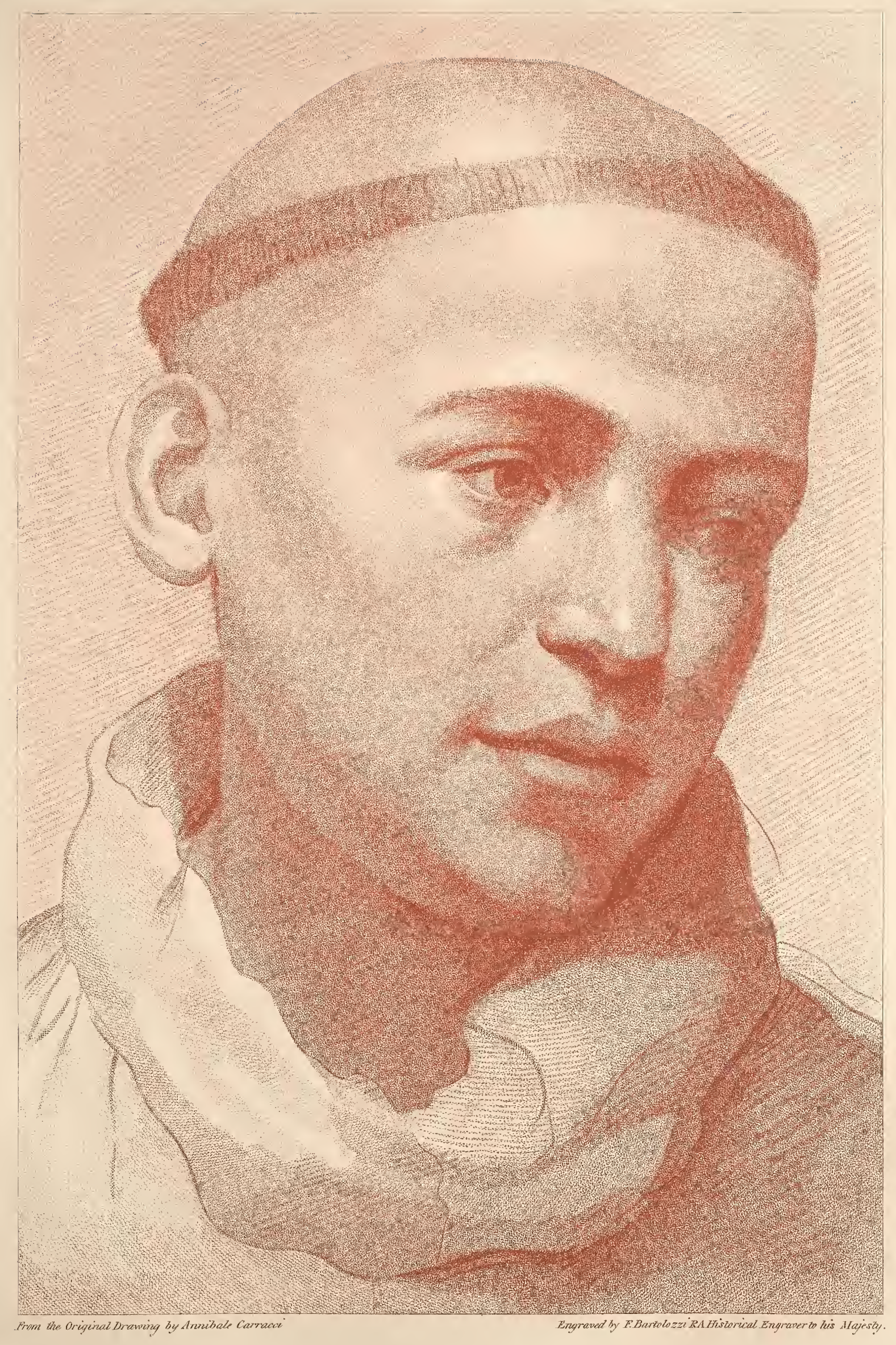







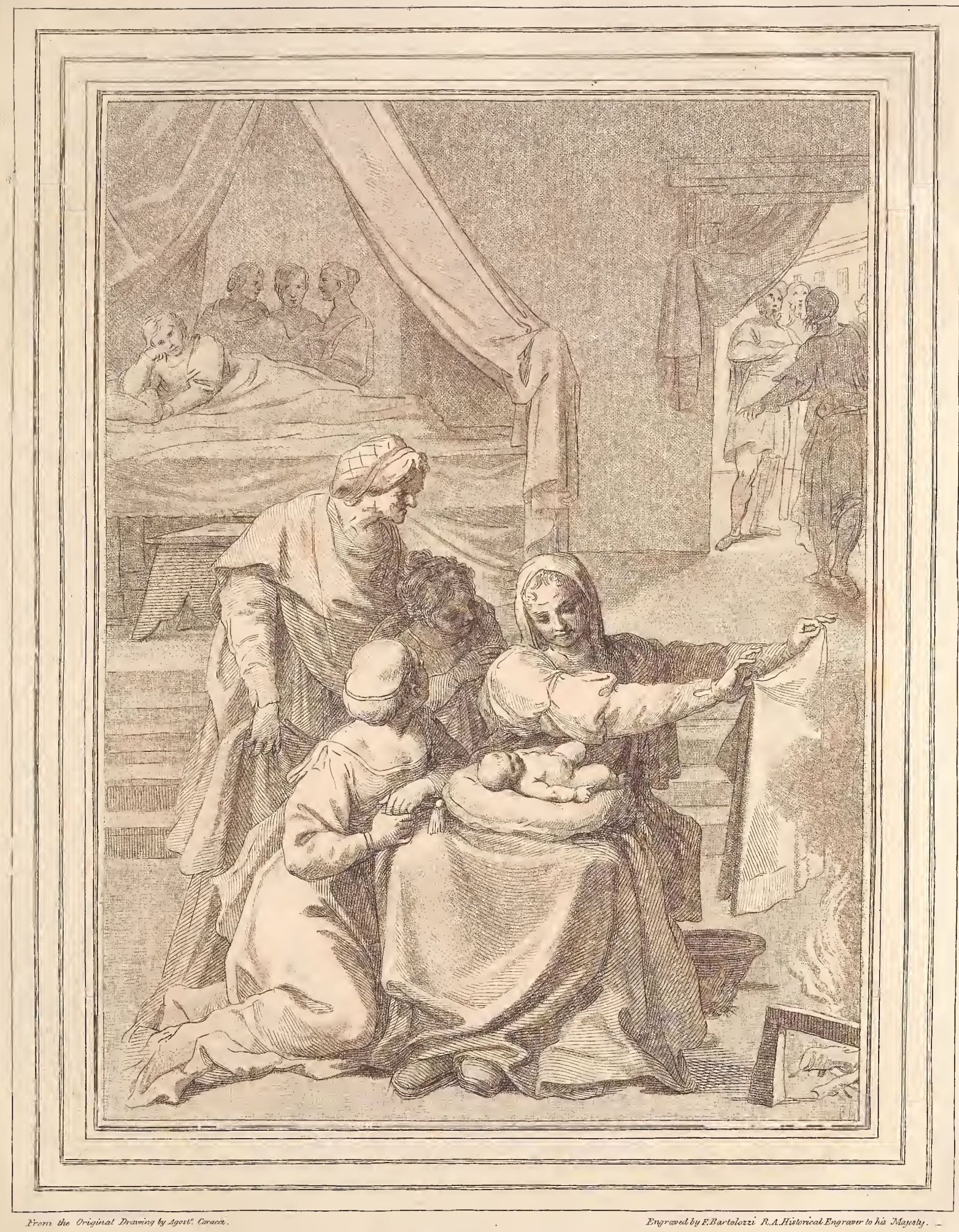







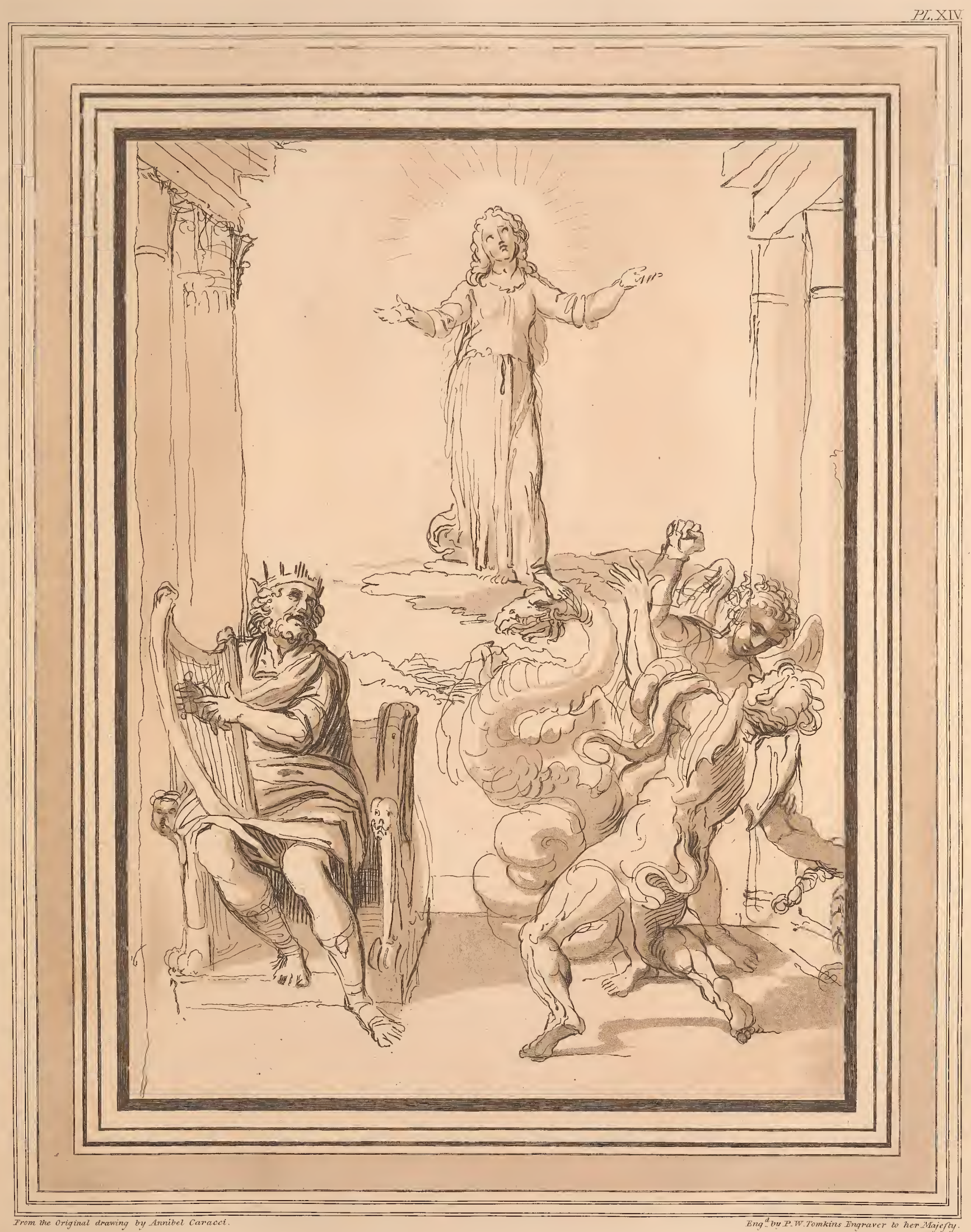

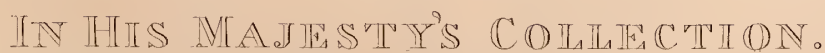


\& 


\section{-}





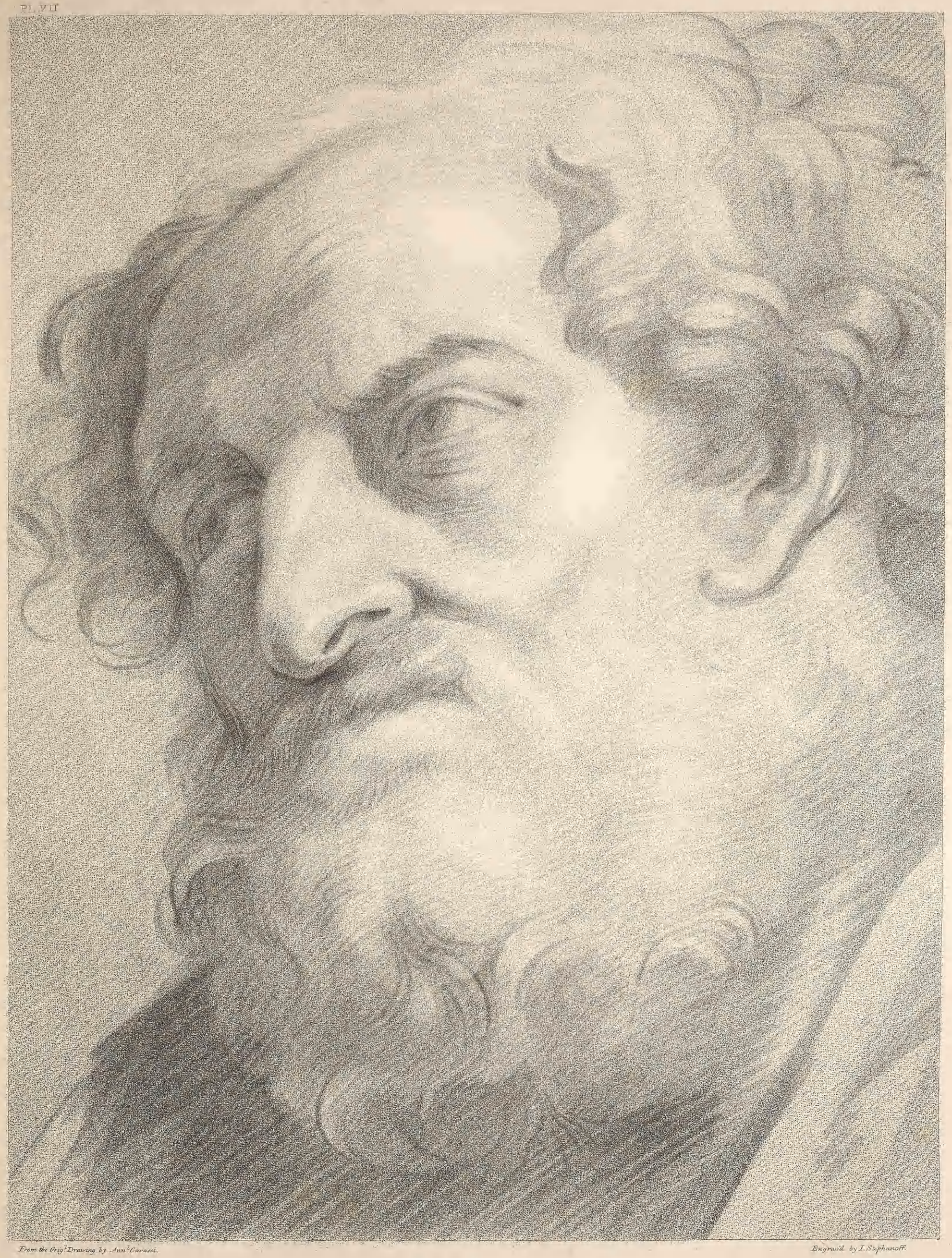







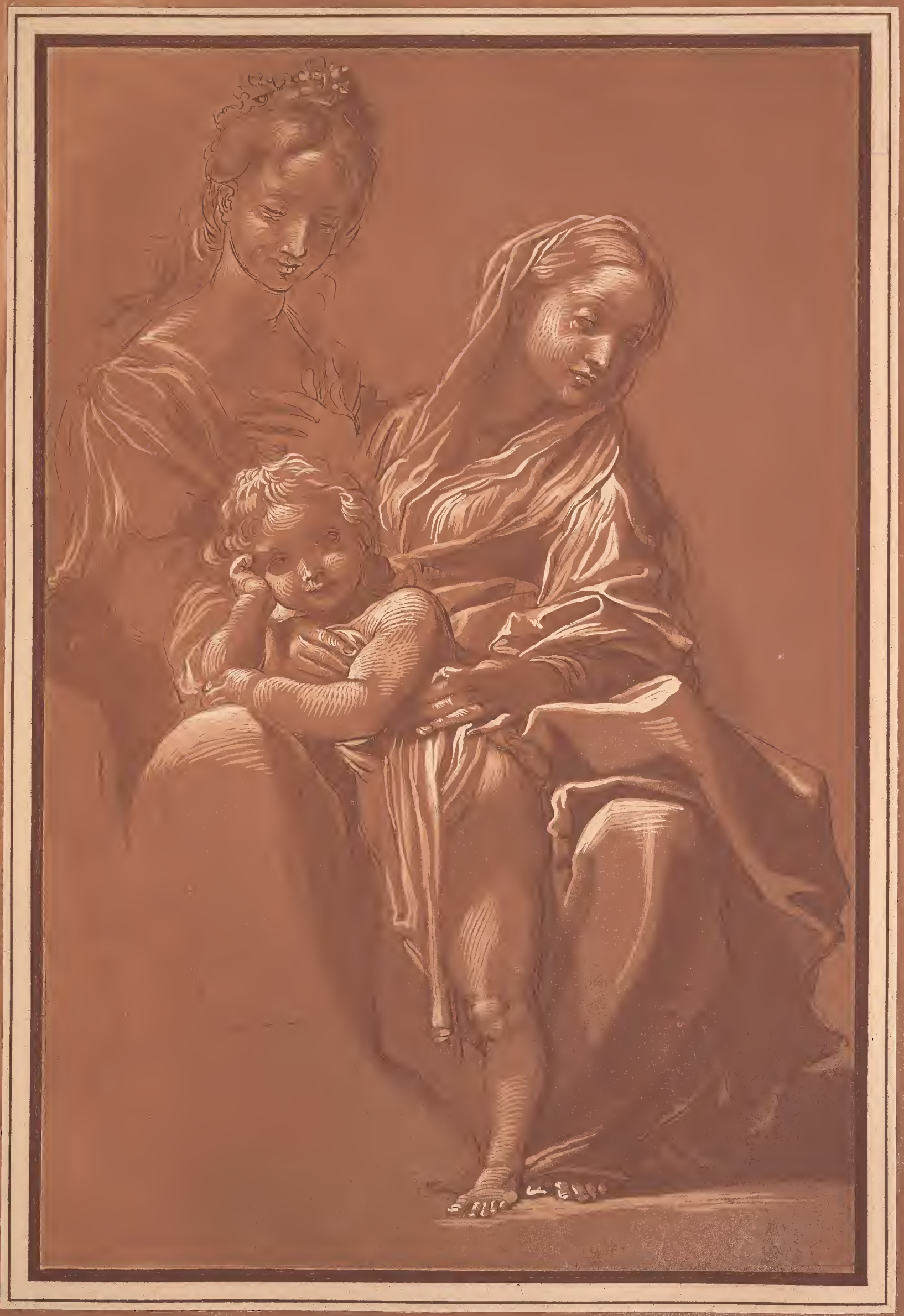

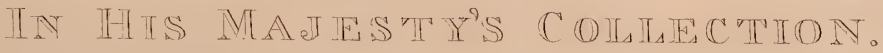







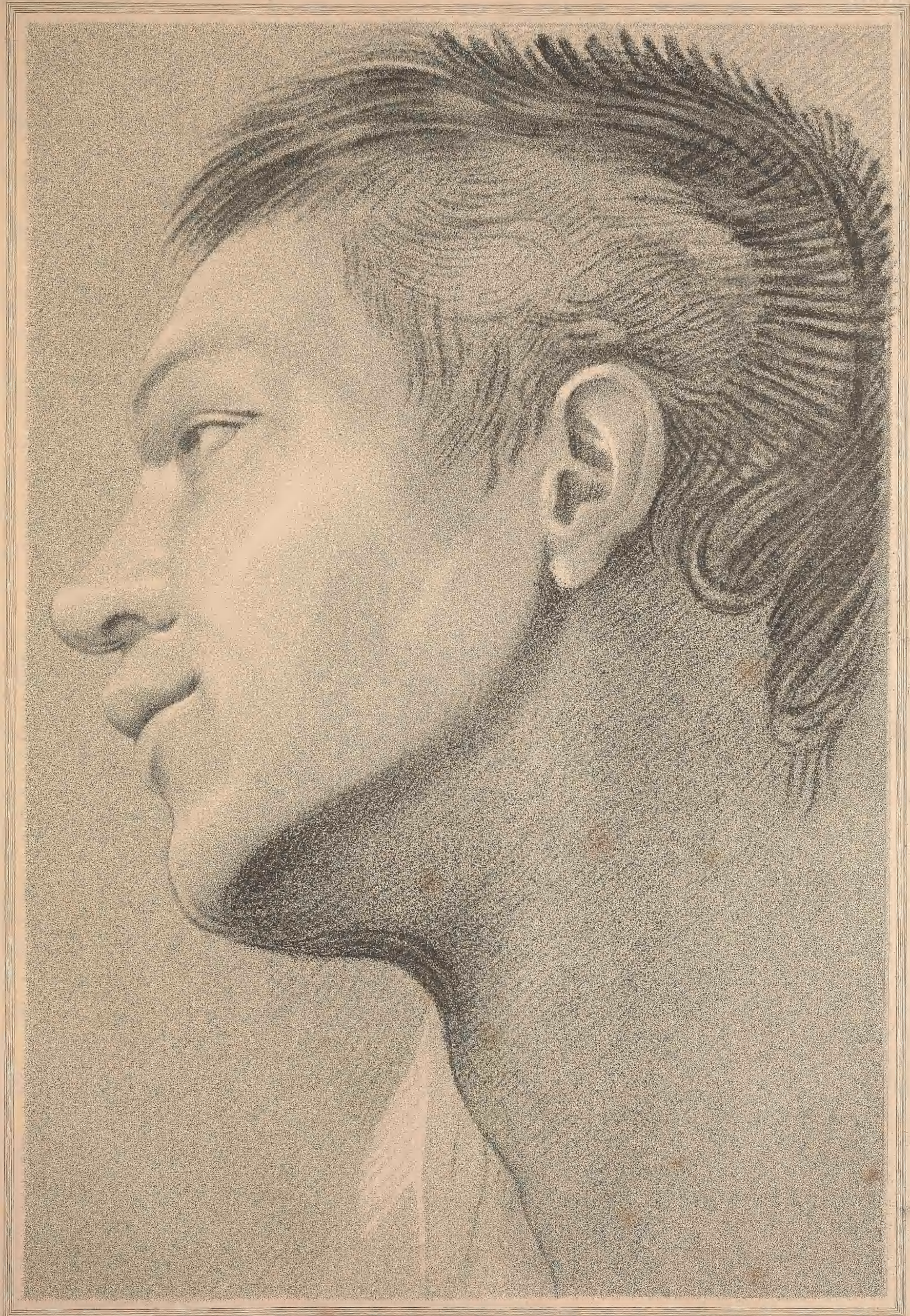

Fom the oniginal drawing by Anniber Caraced

Enyravil hy is S Facit

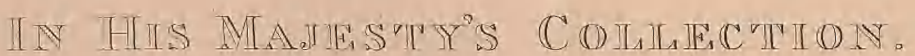







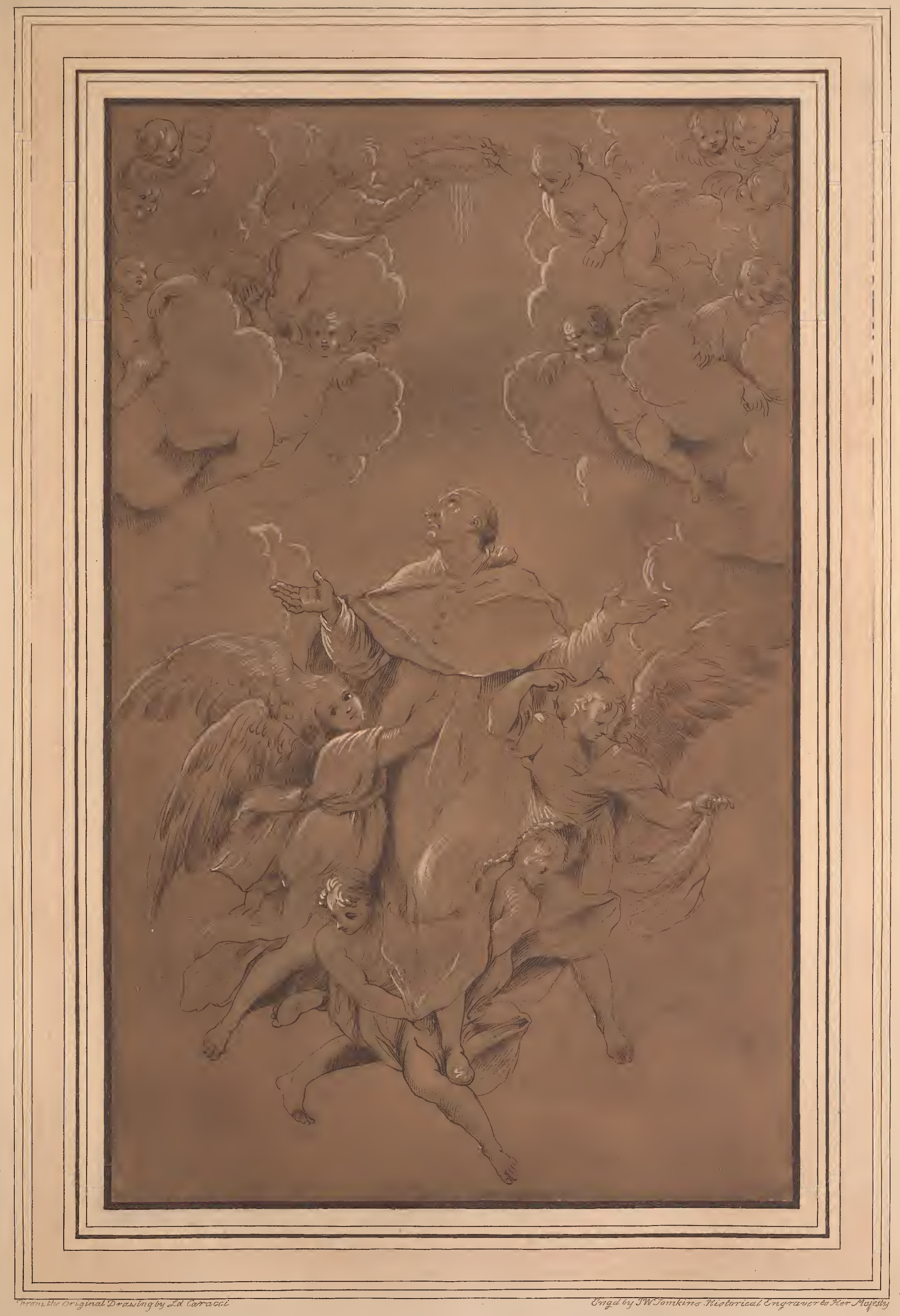

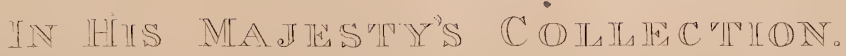





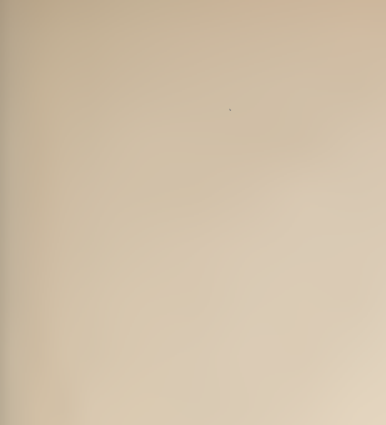





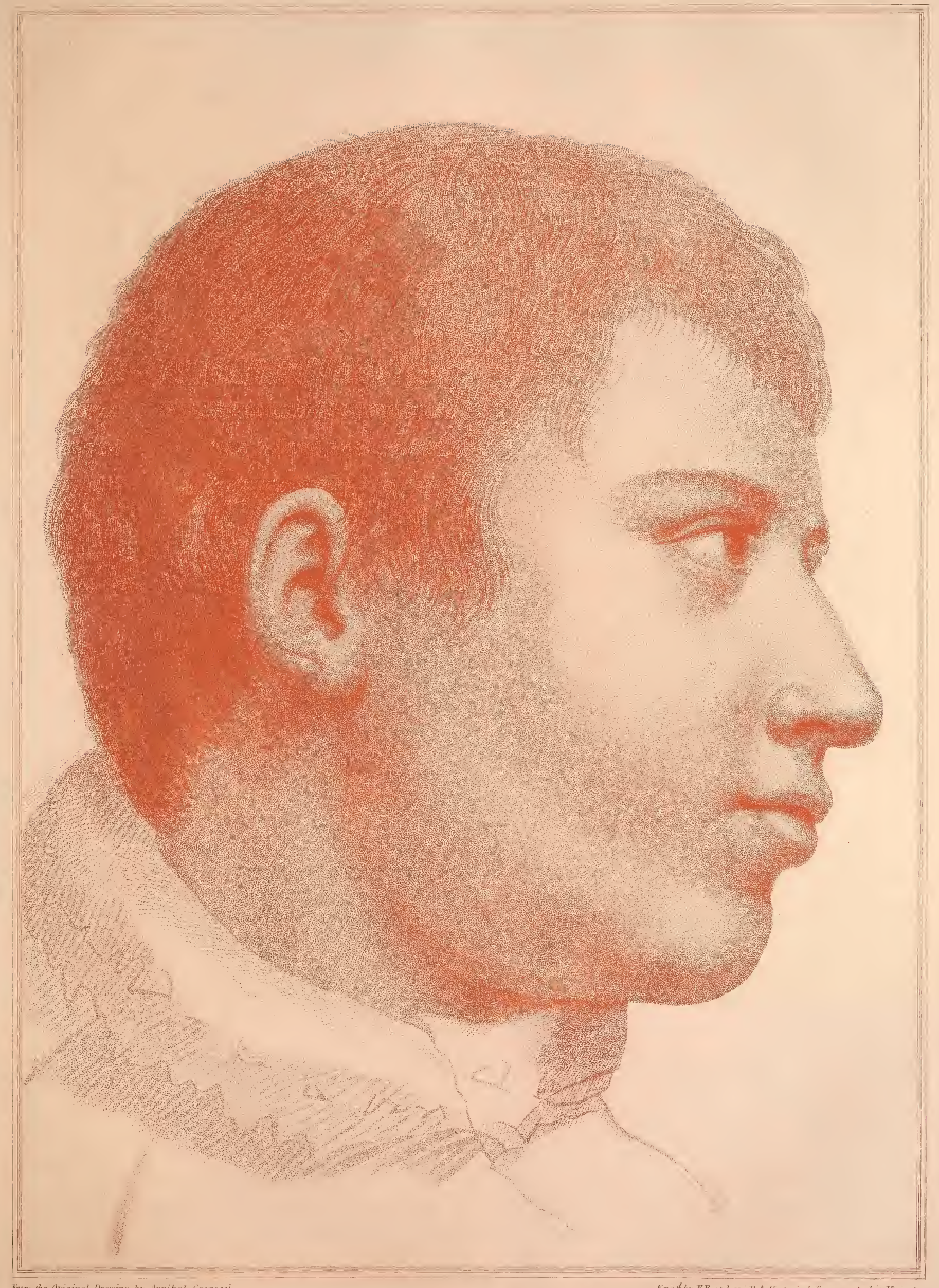

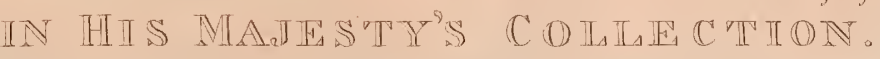







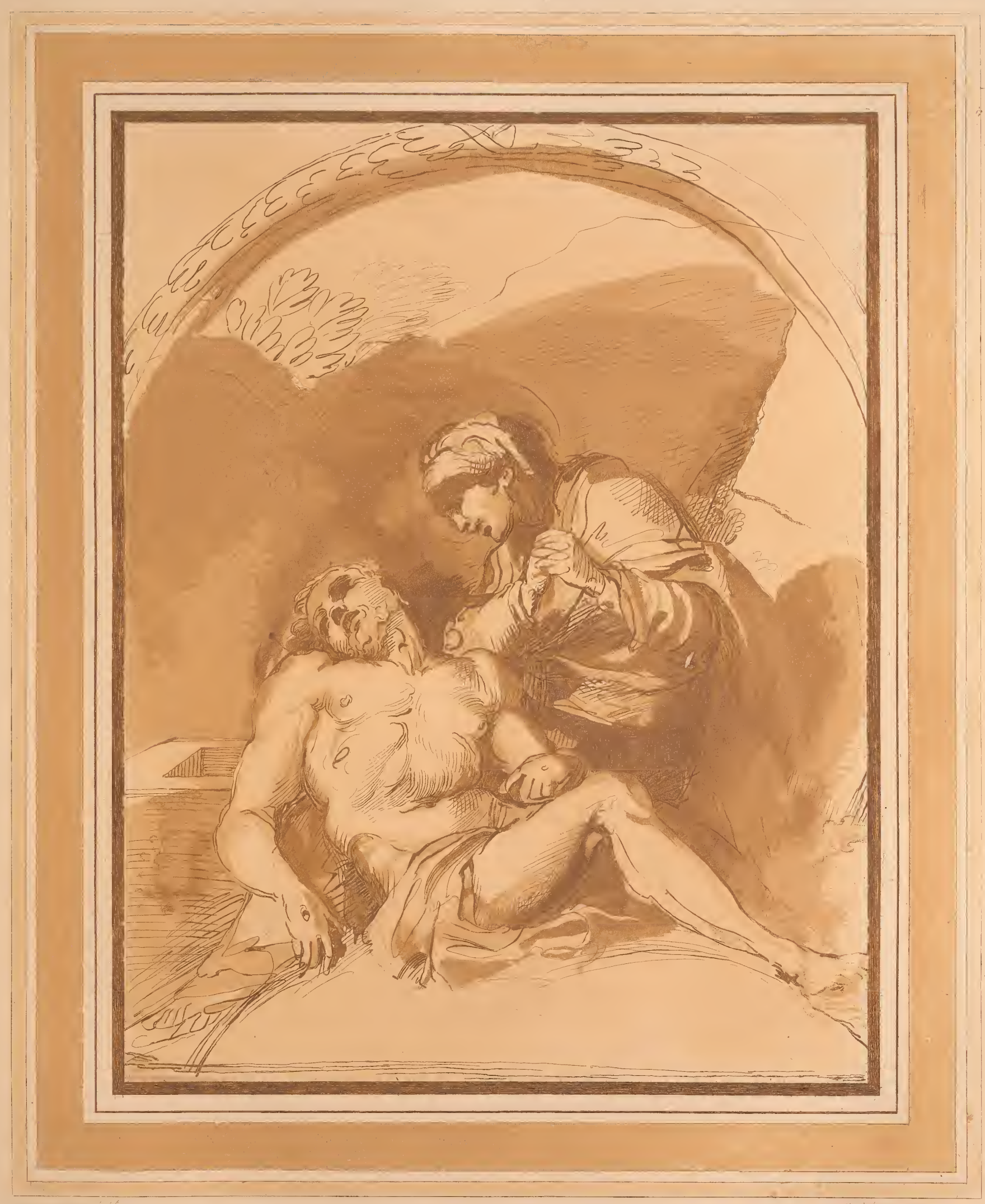

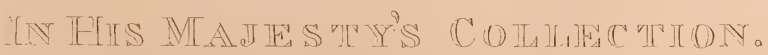




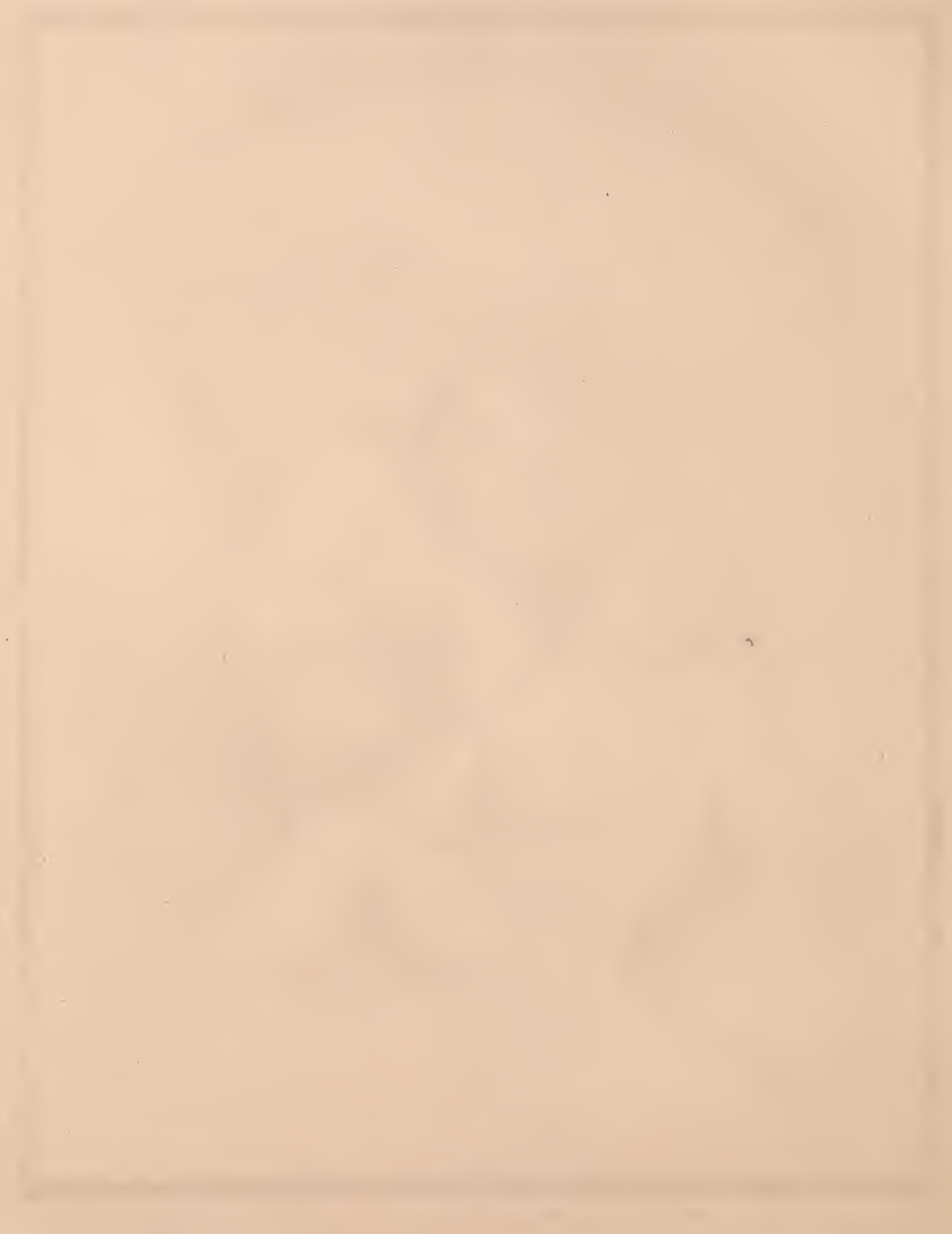





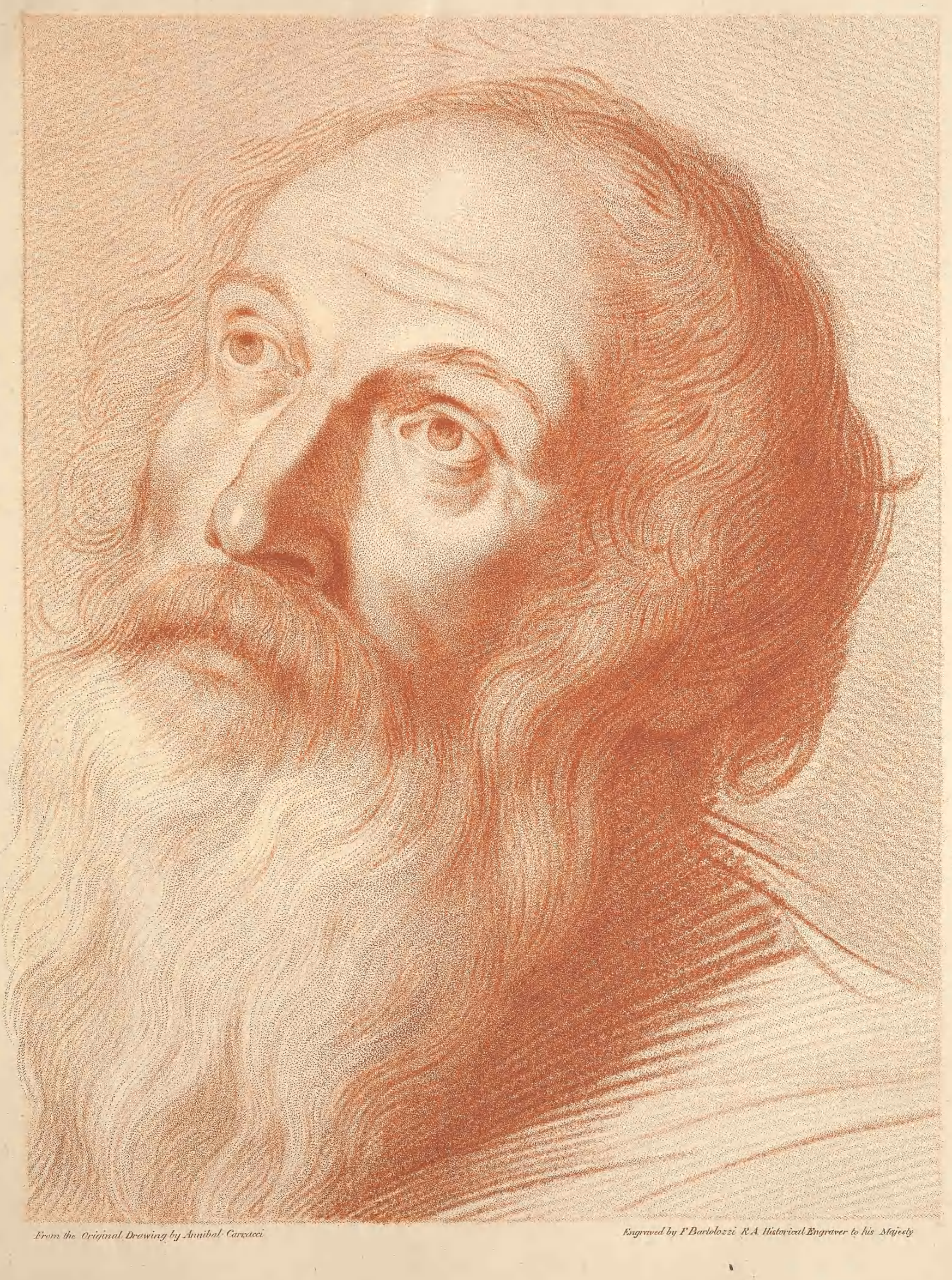

IN HIIS MLAJESTY'S C DLLTC TIDN, 




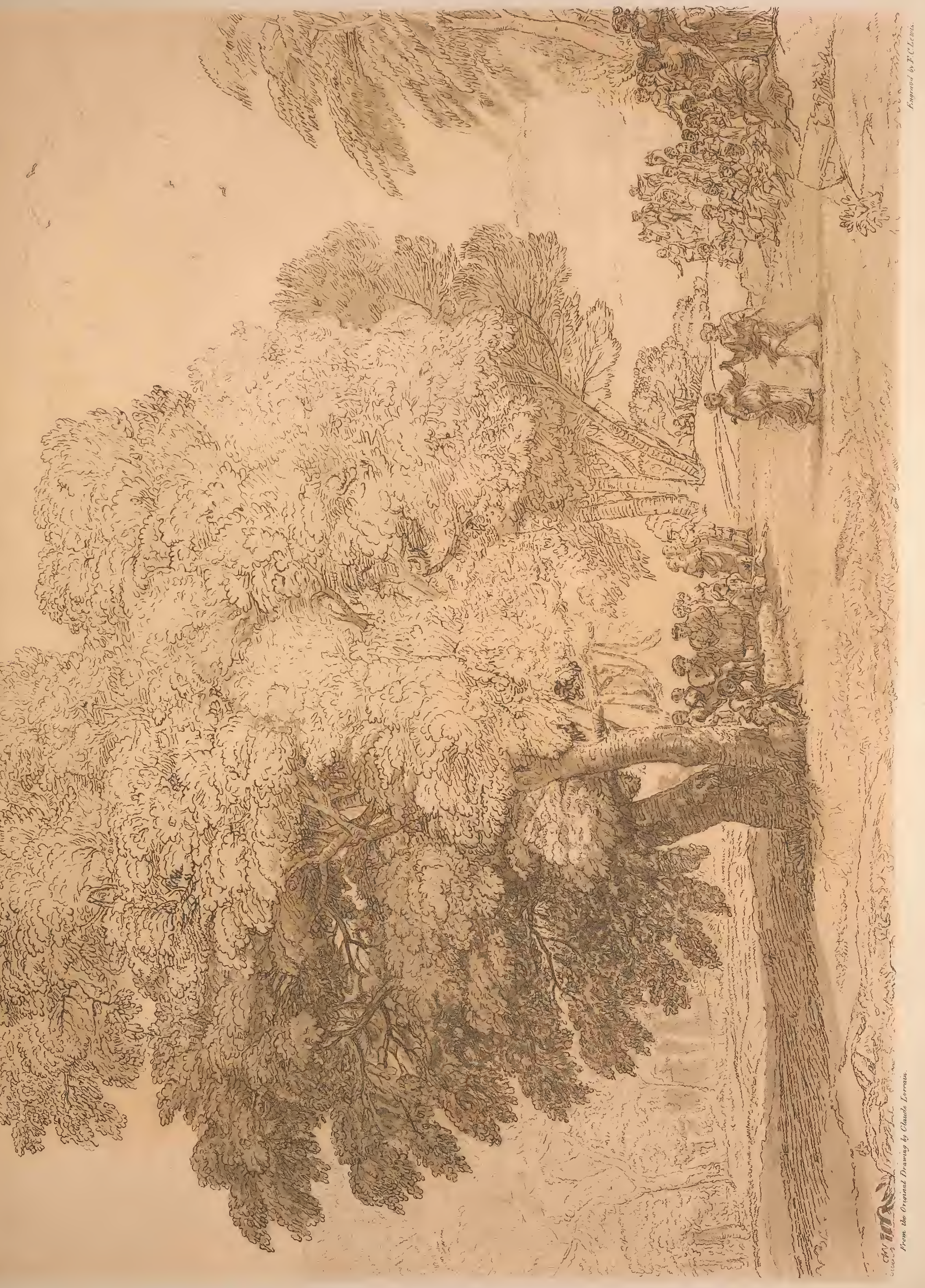




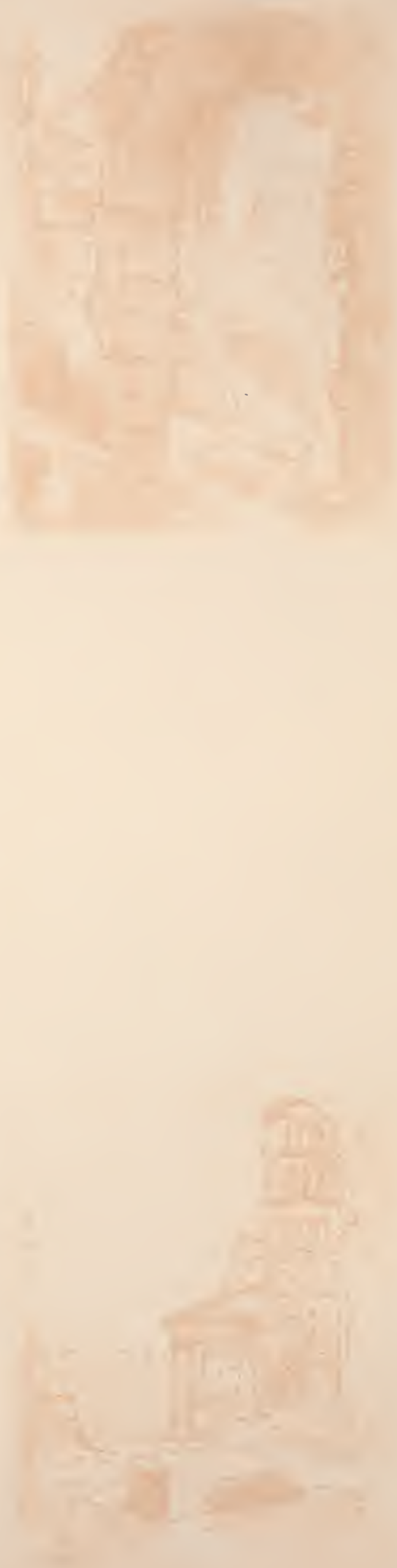

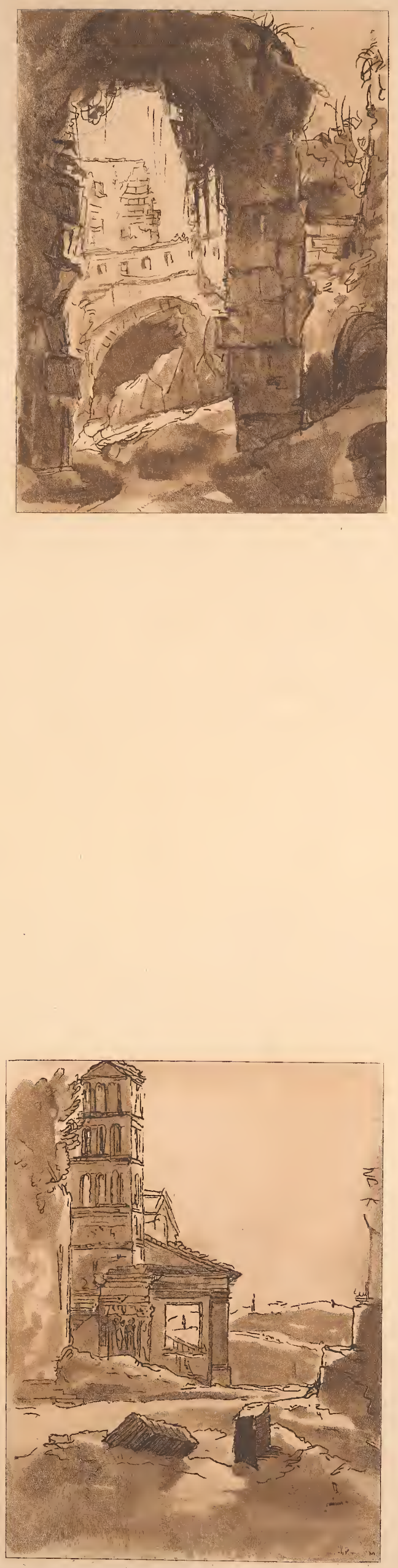




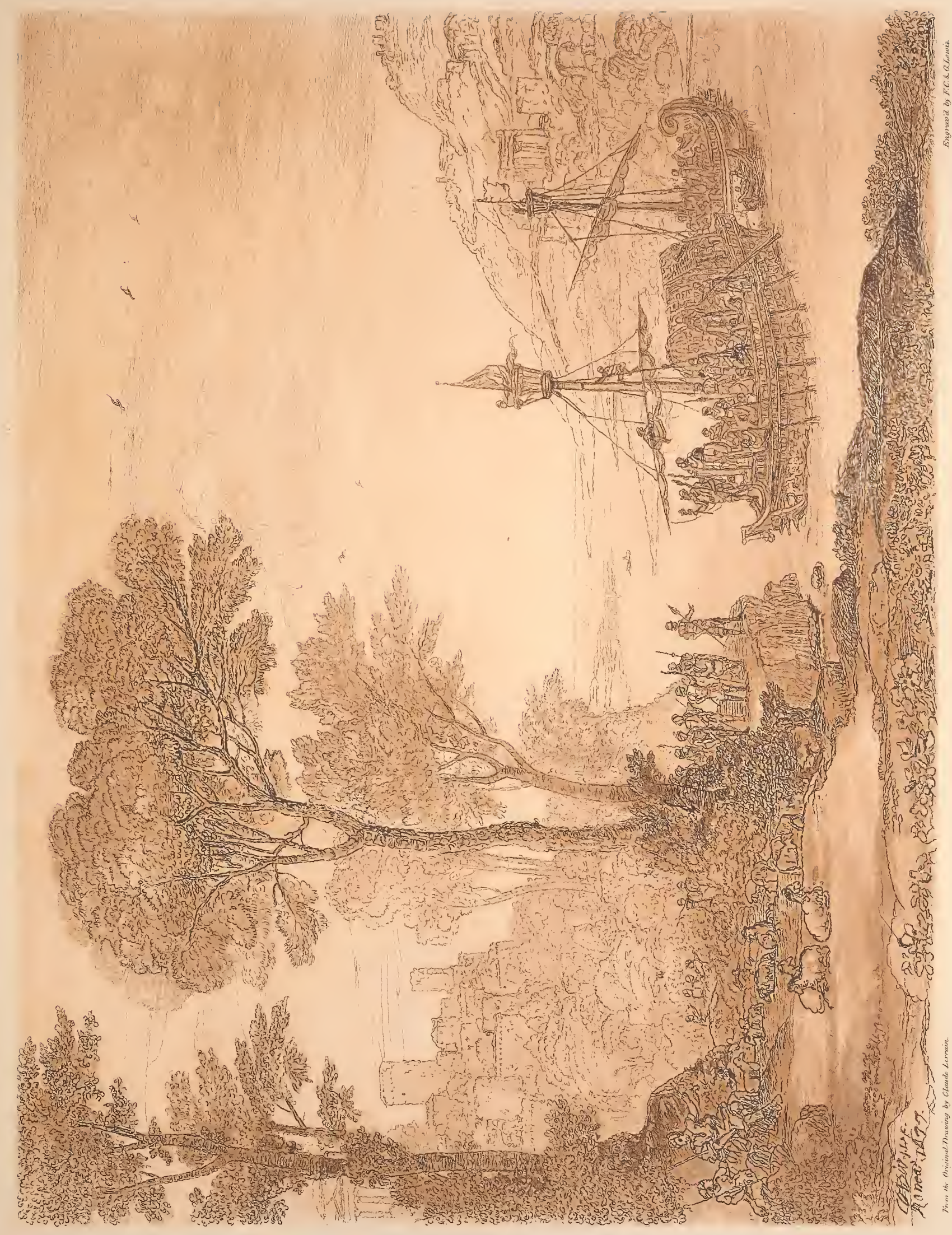






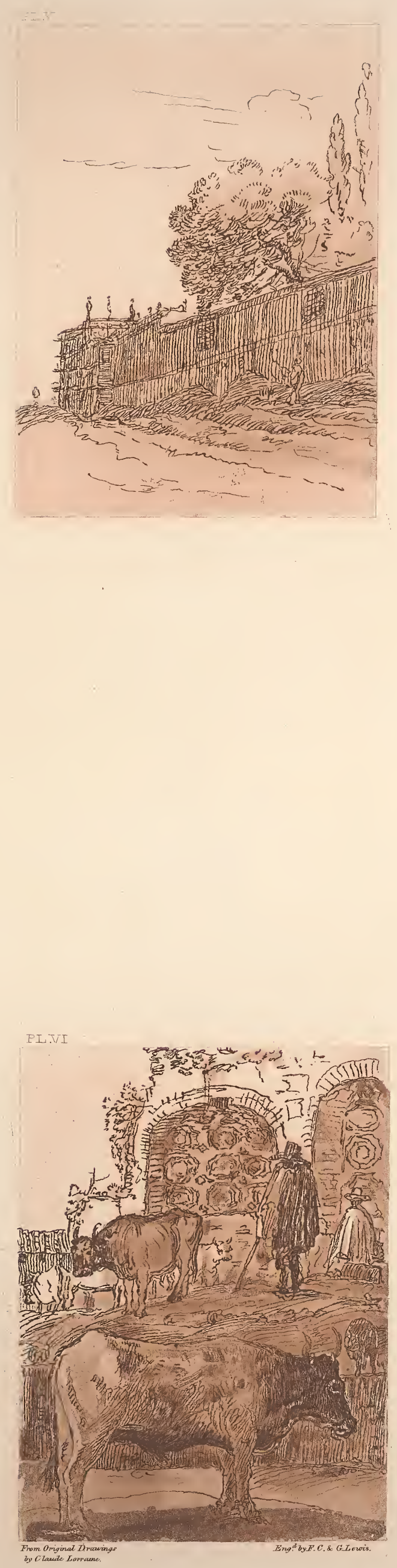

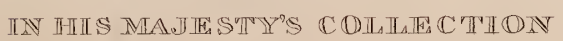





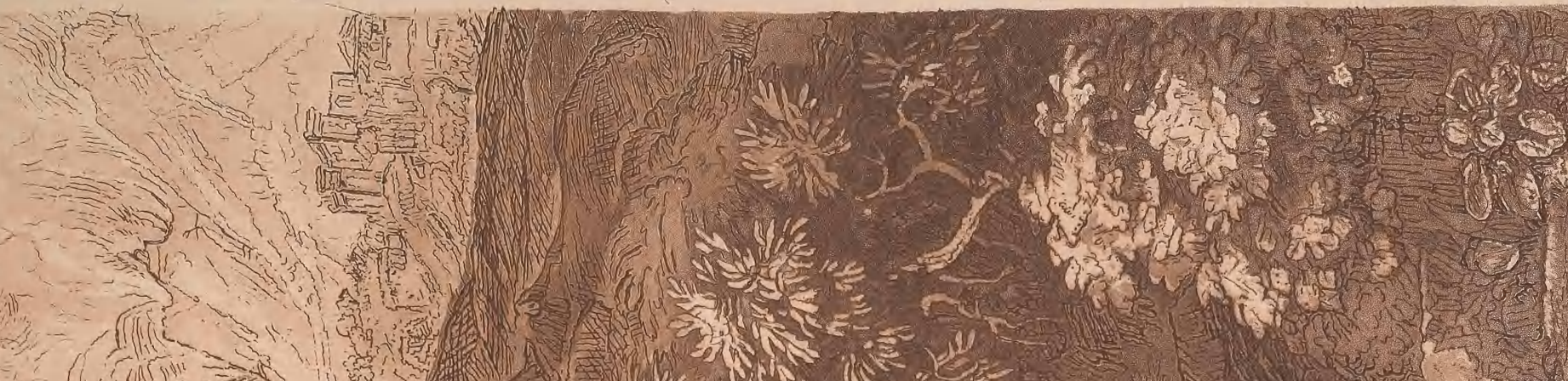

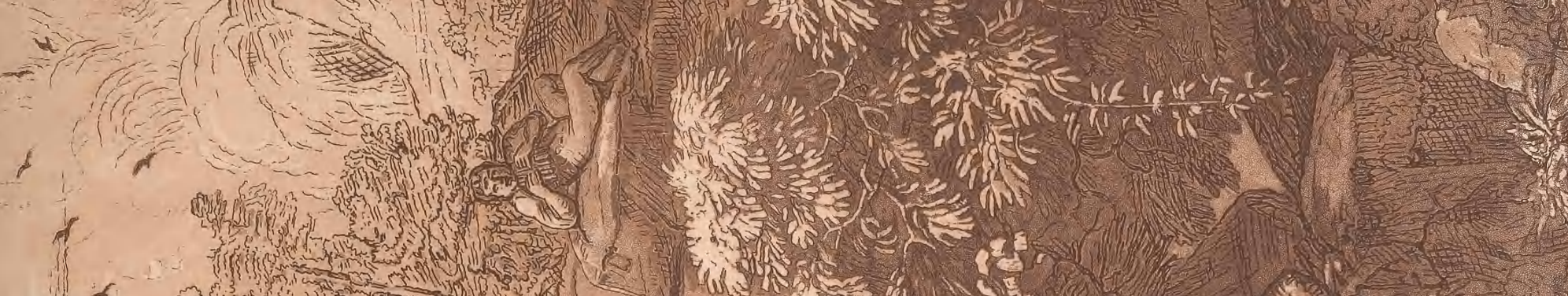

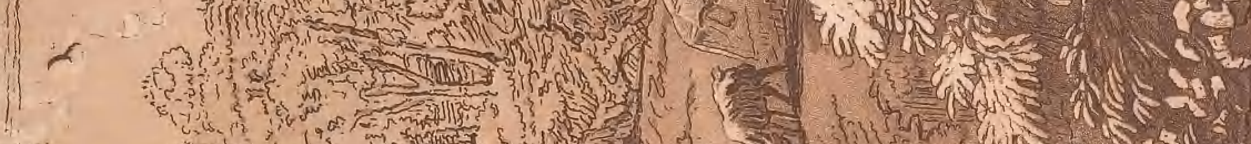

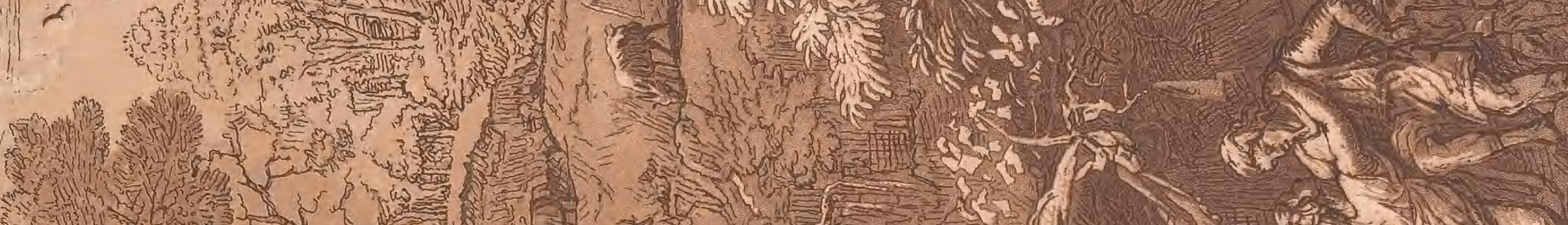
3.1.

1.1.

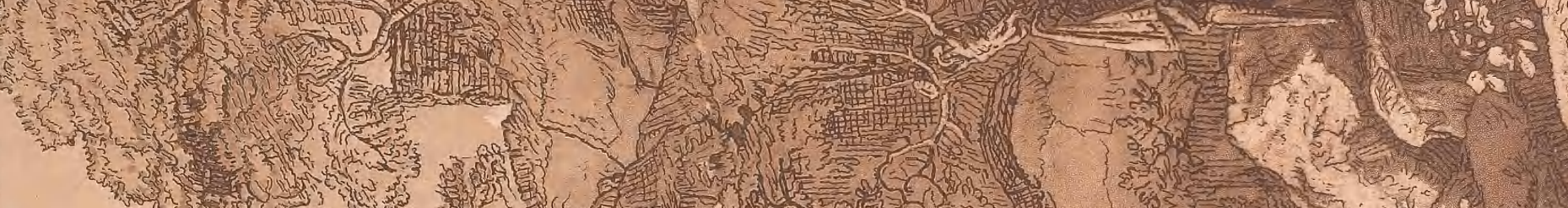

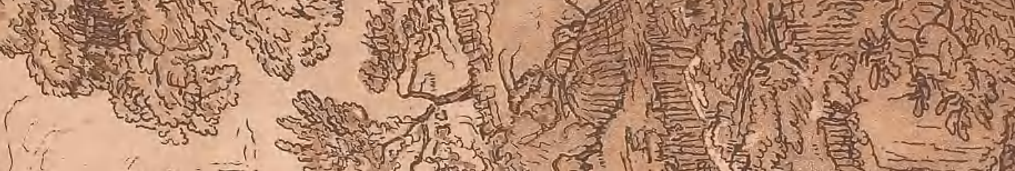

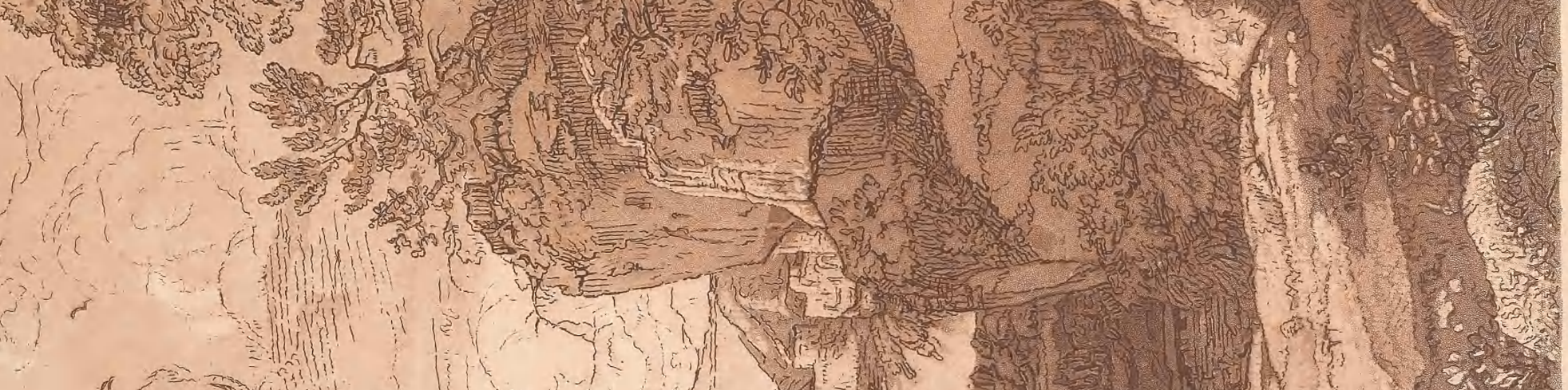

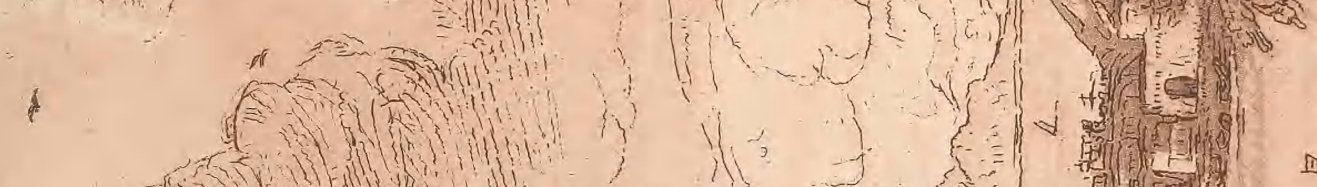

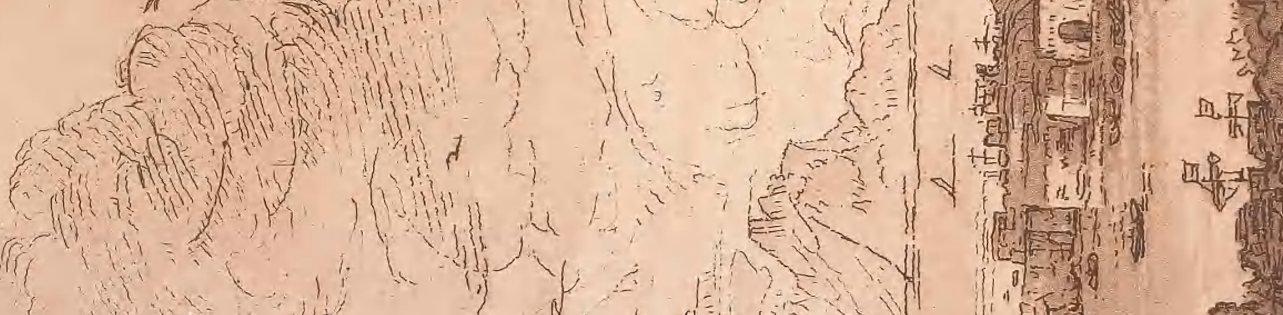

z

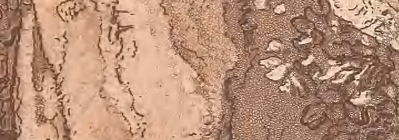

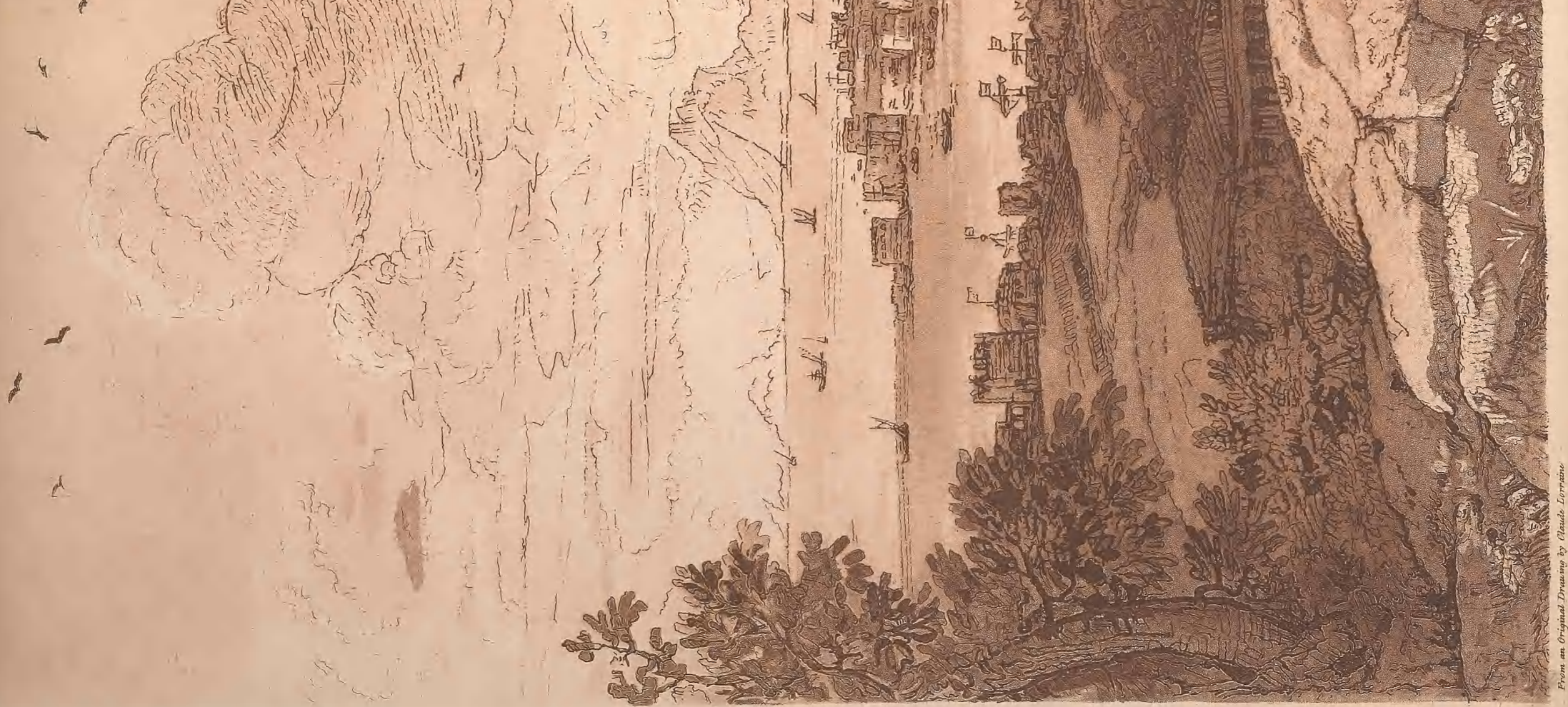






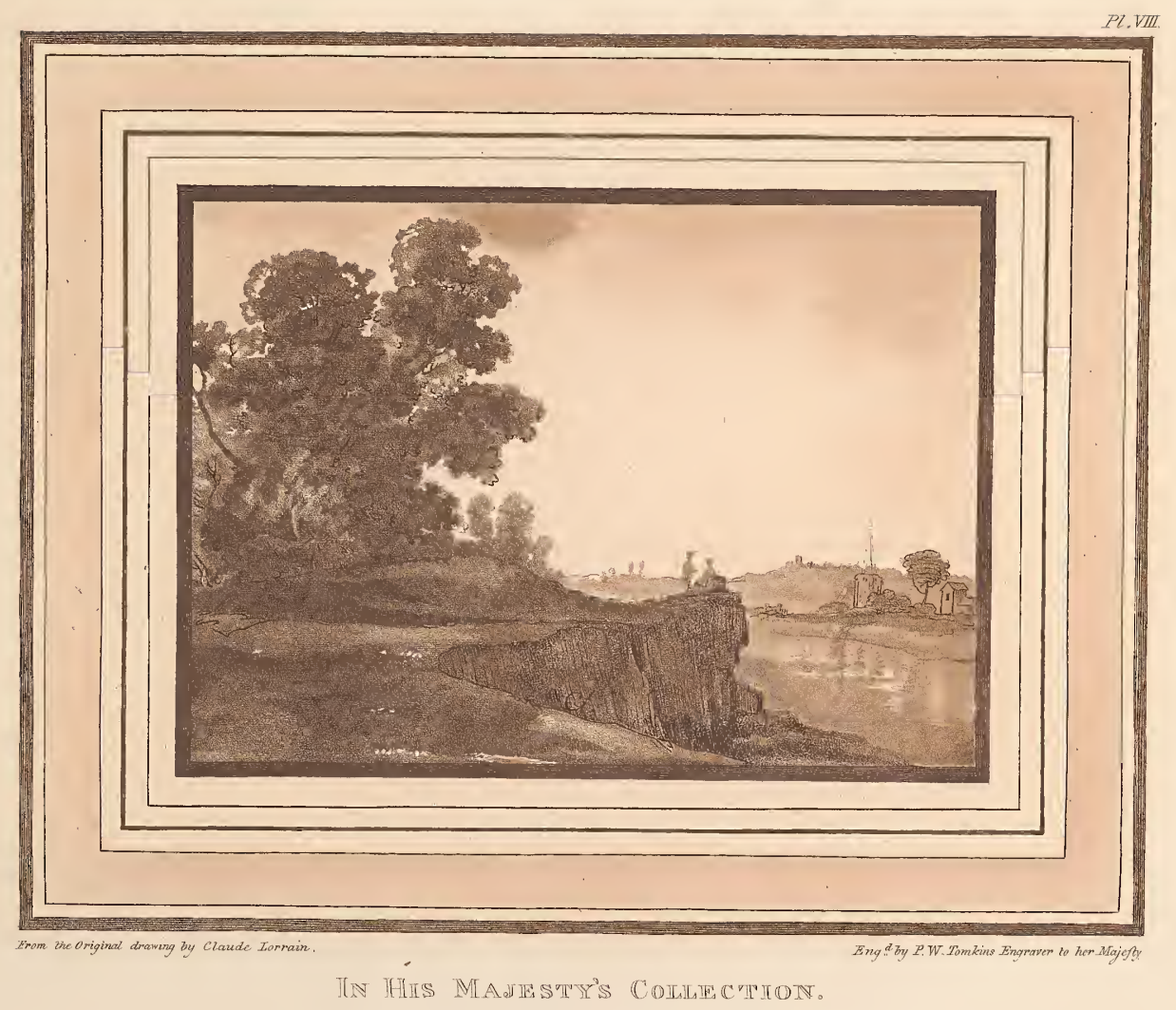






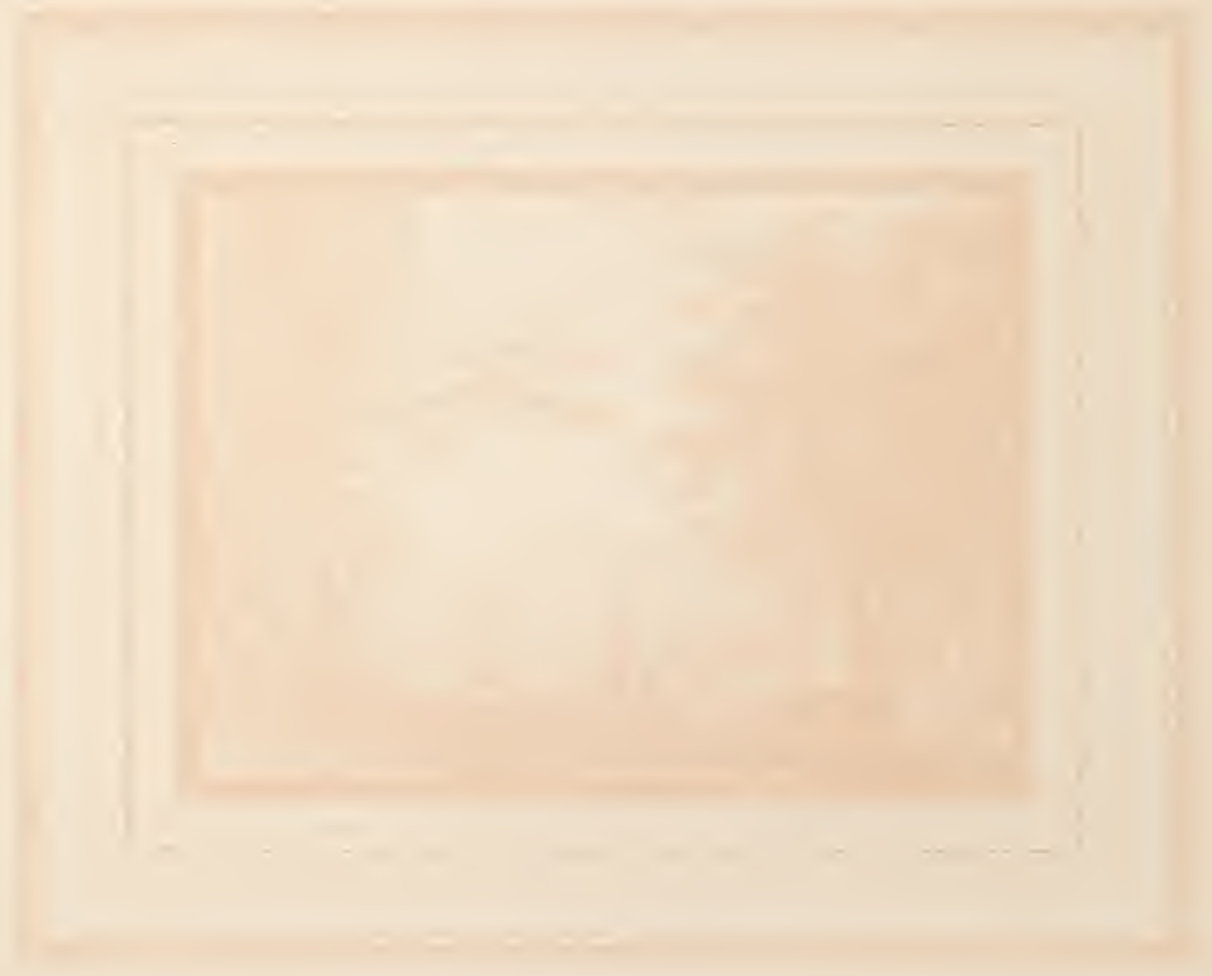




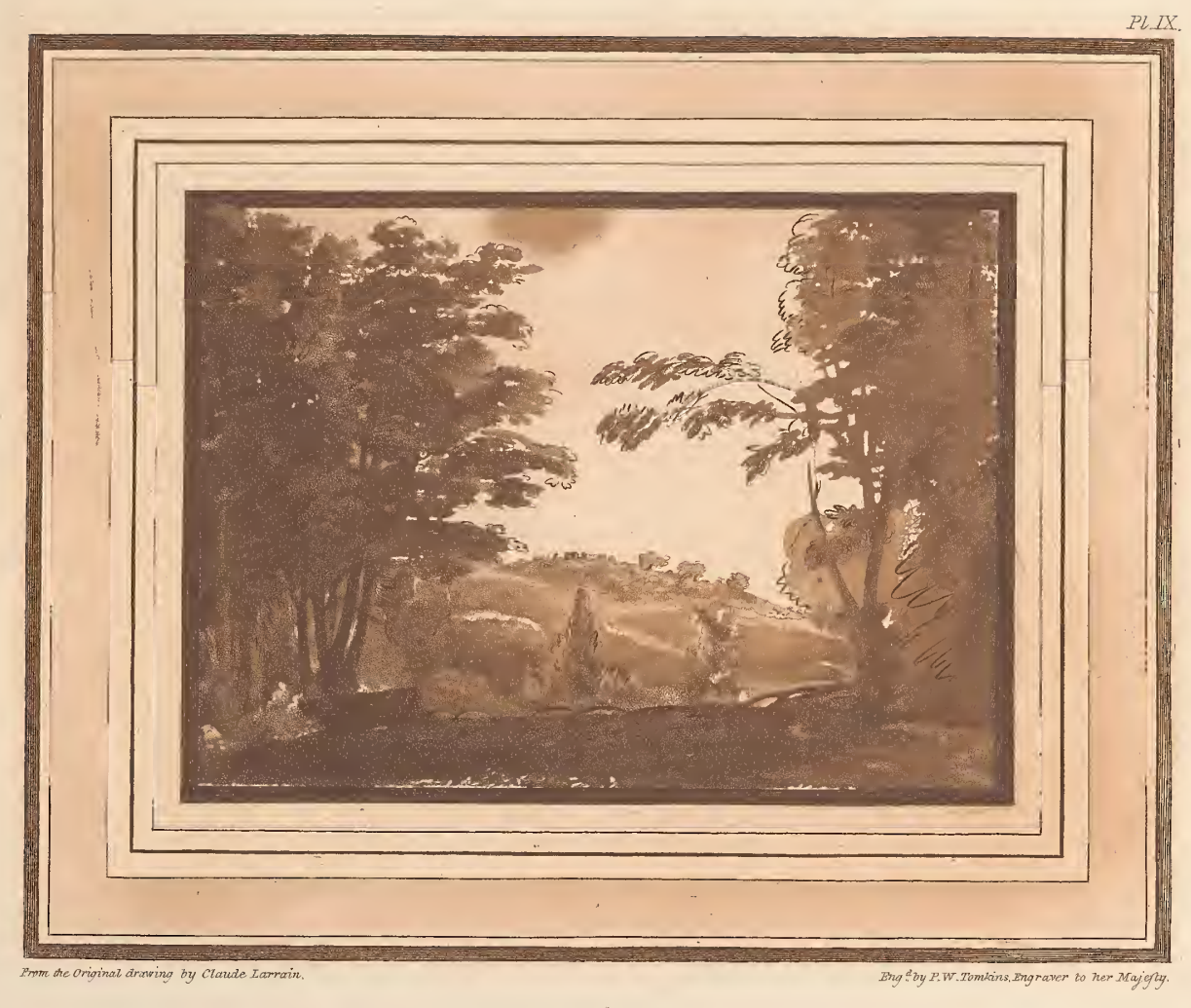

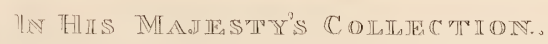





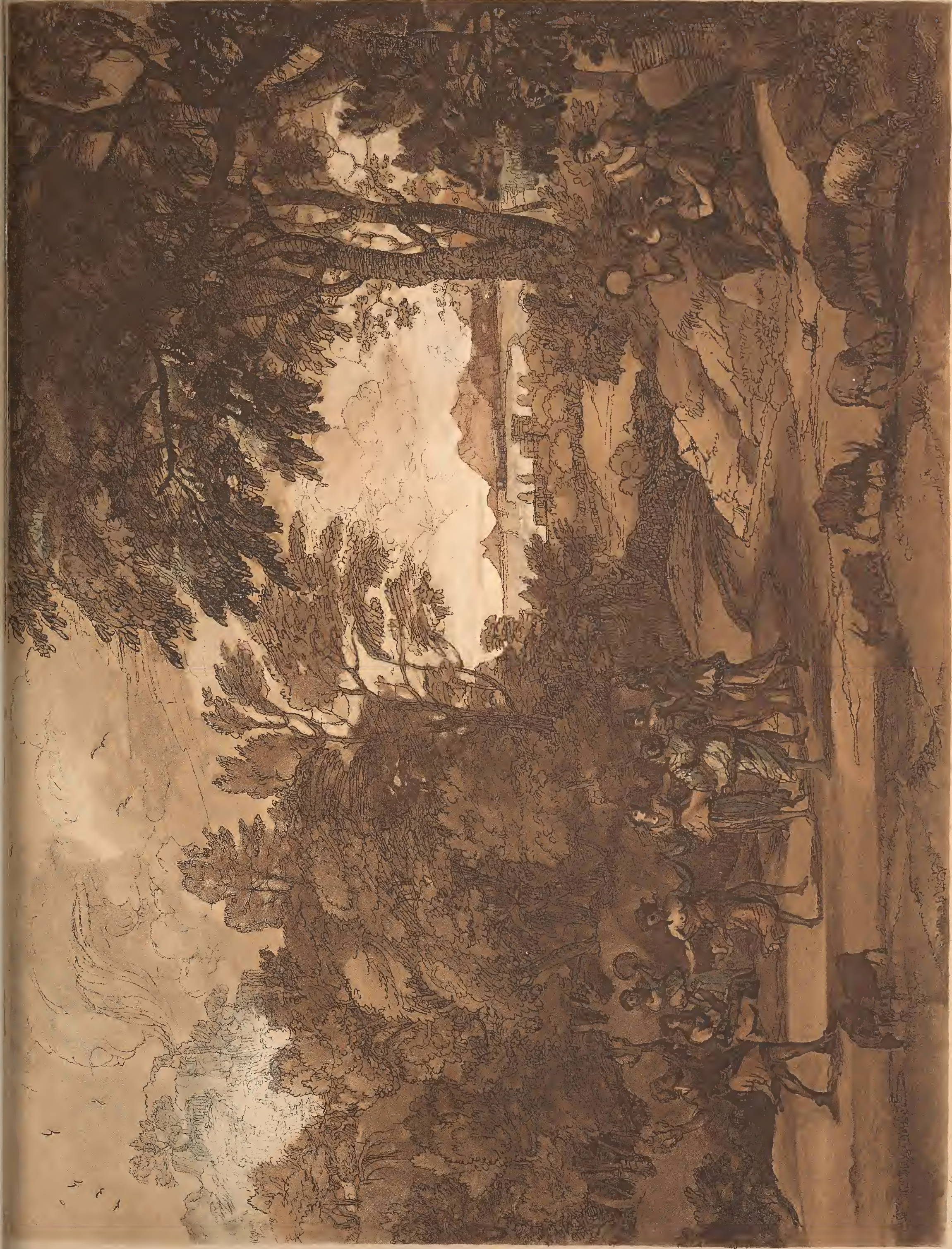






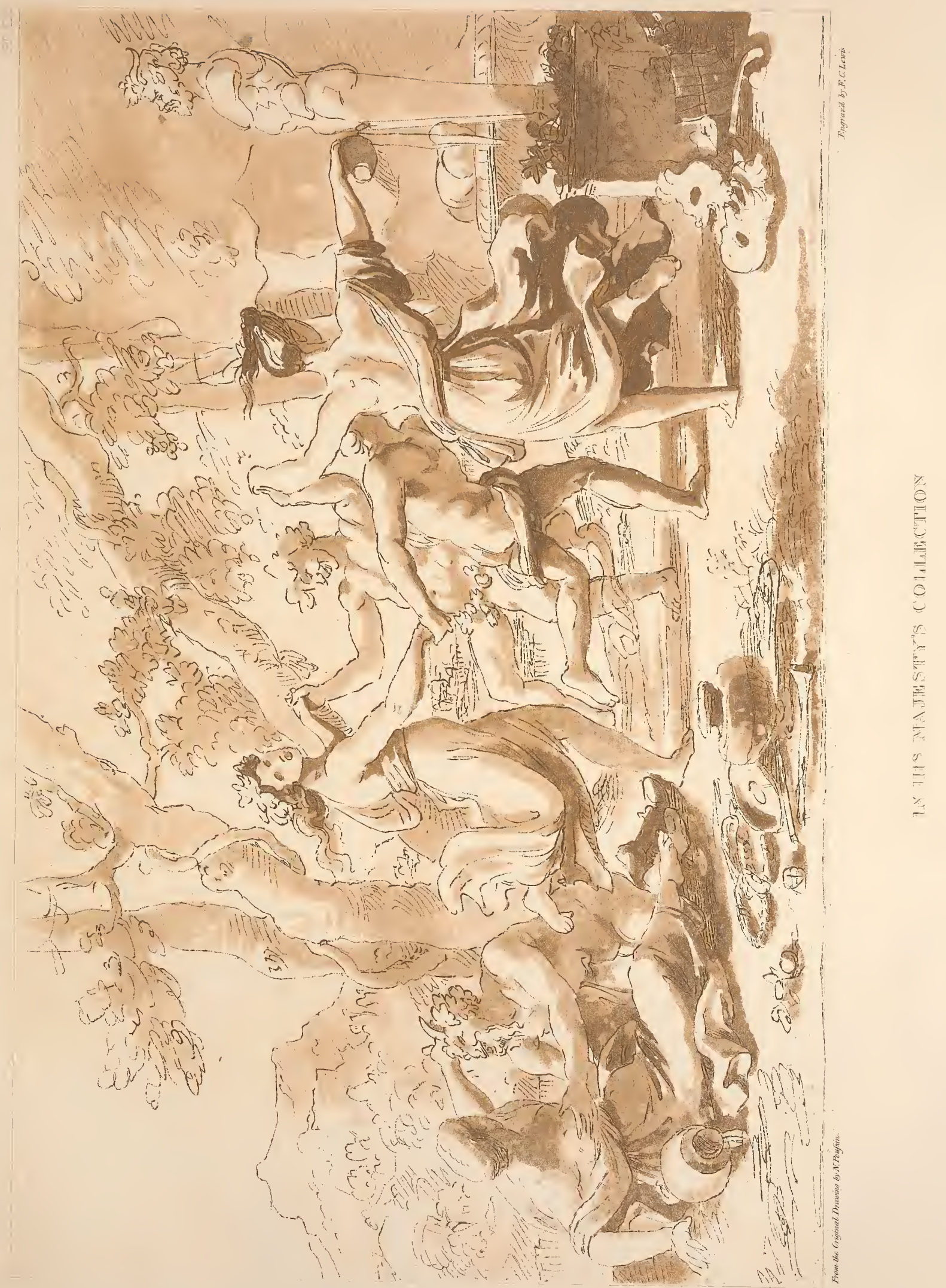






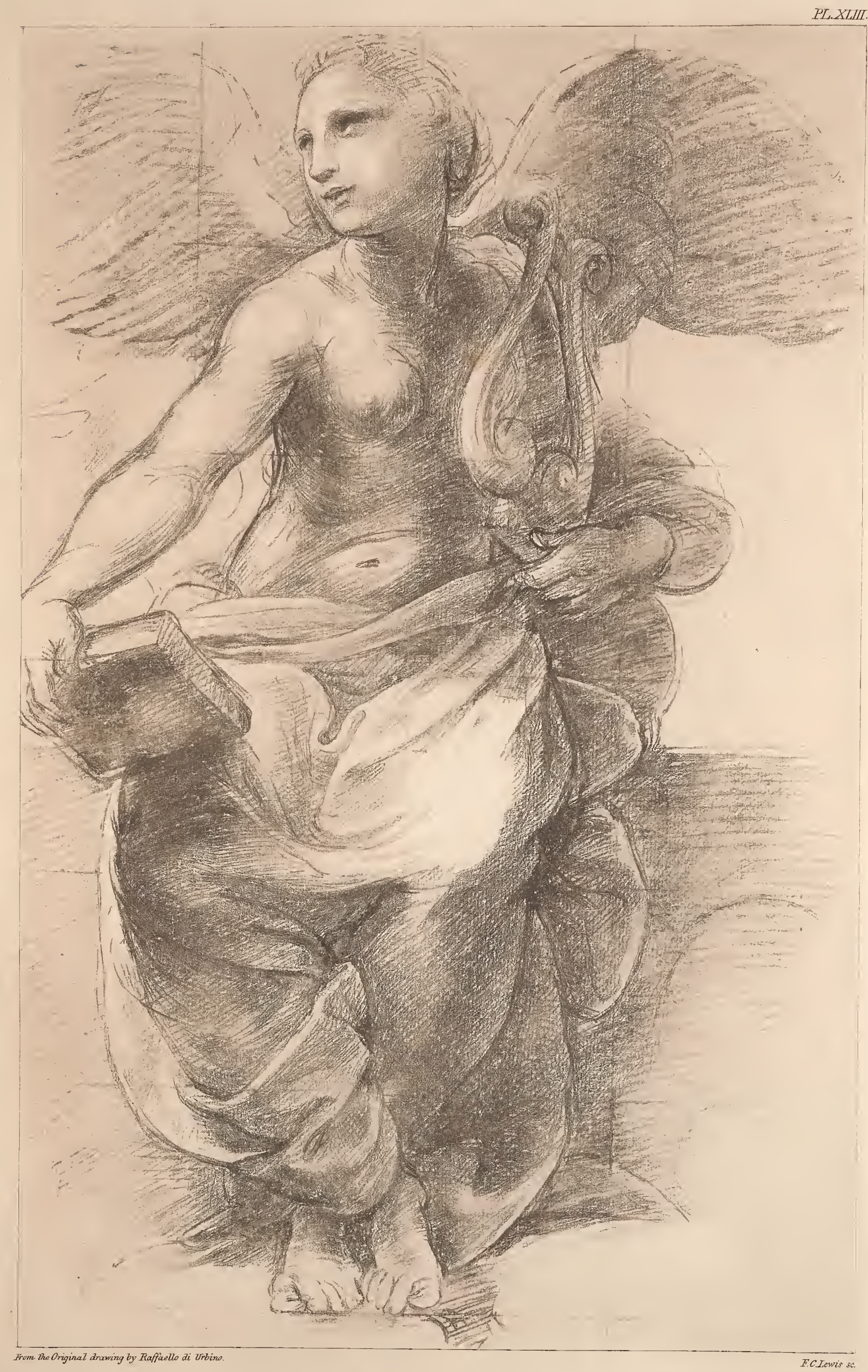

IN HIIS MAAJESTY'S COLLECTION。 





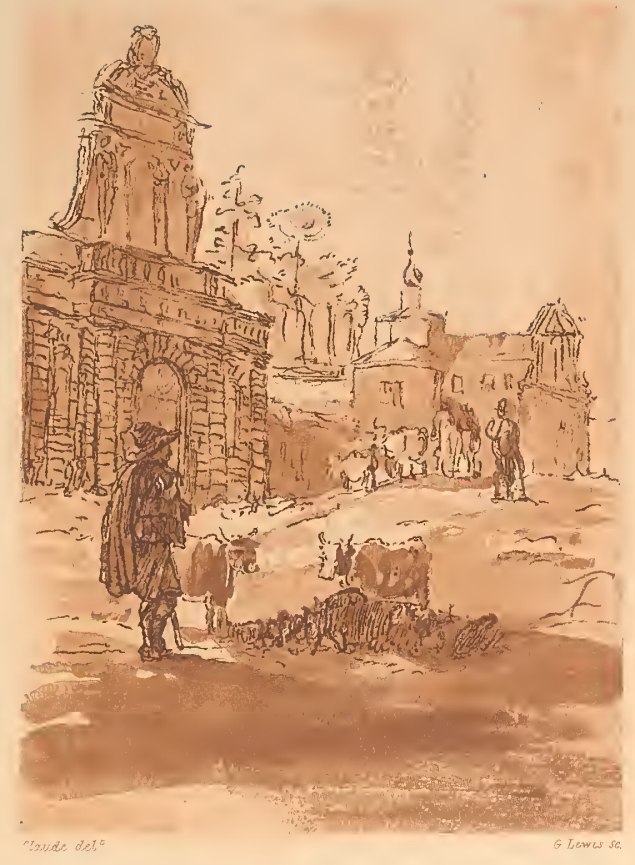

F'L XIV.

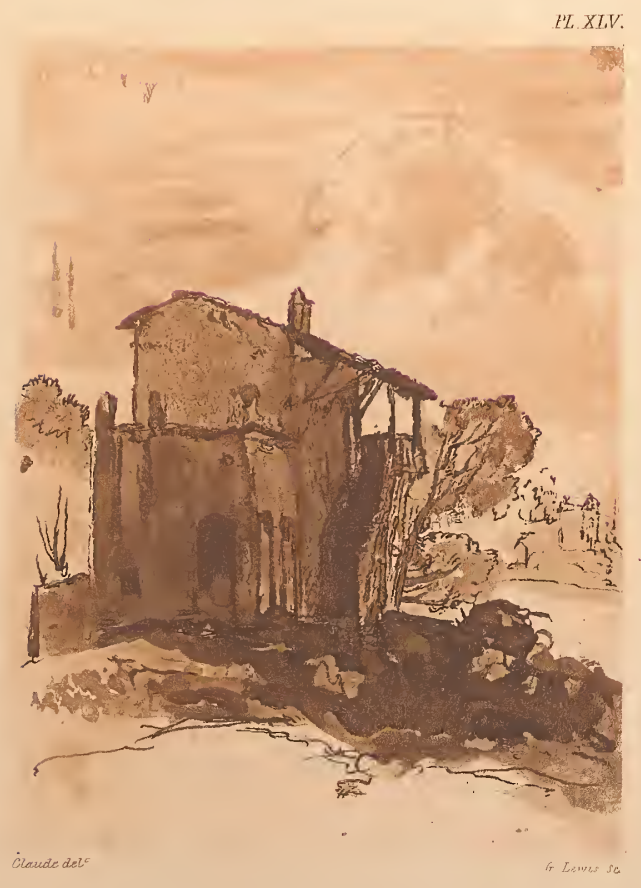





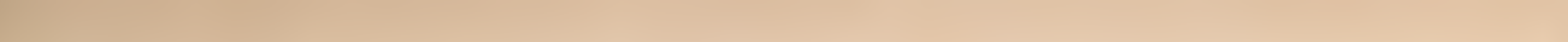



PL.XIVI.

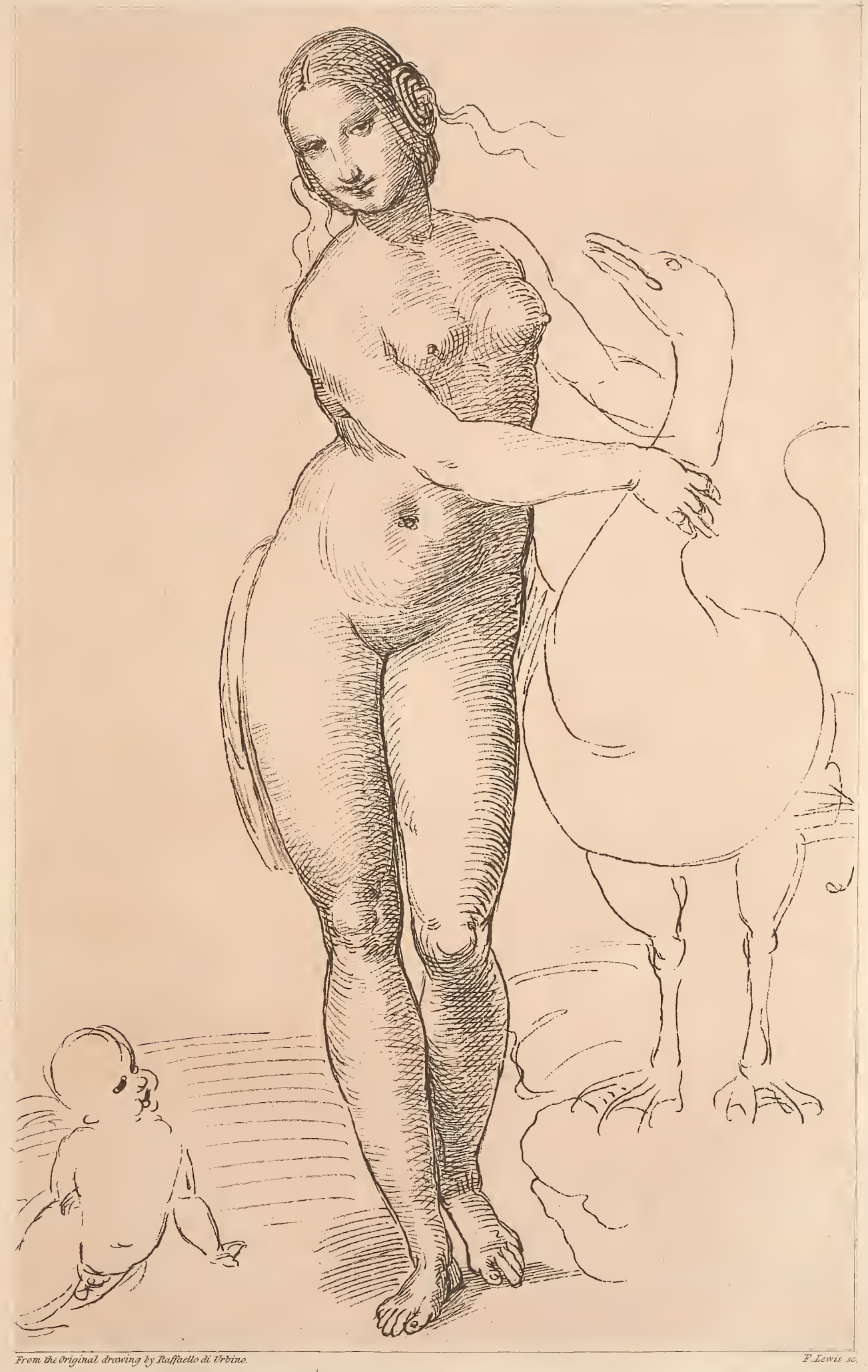

IN HIIS MAJESTTY'S COLIIACTIION 。 
. 




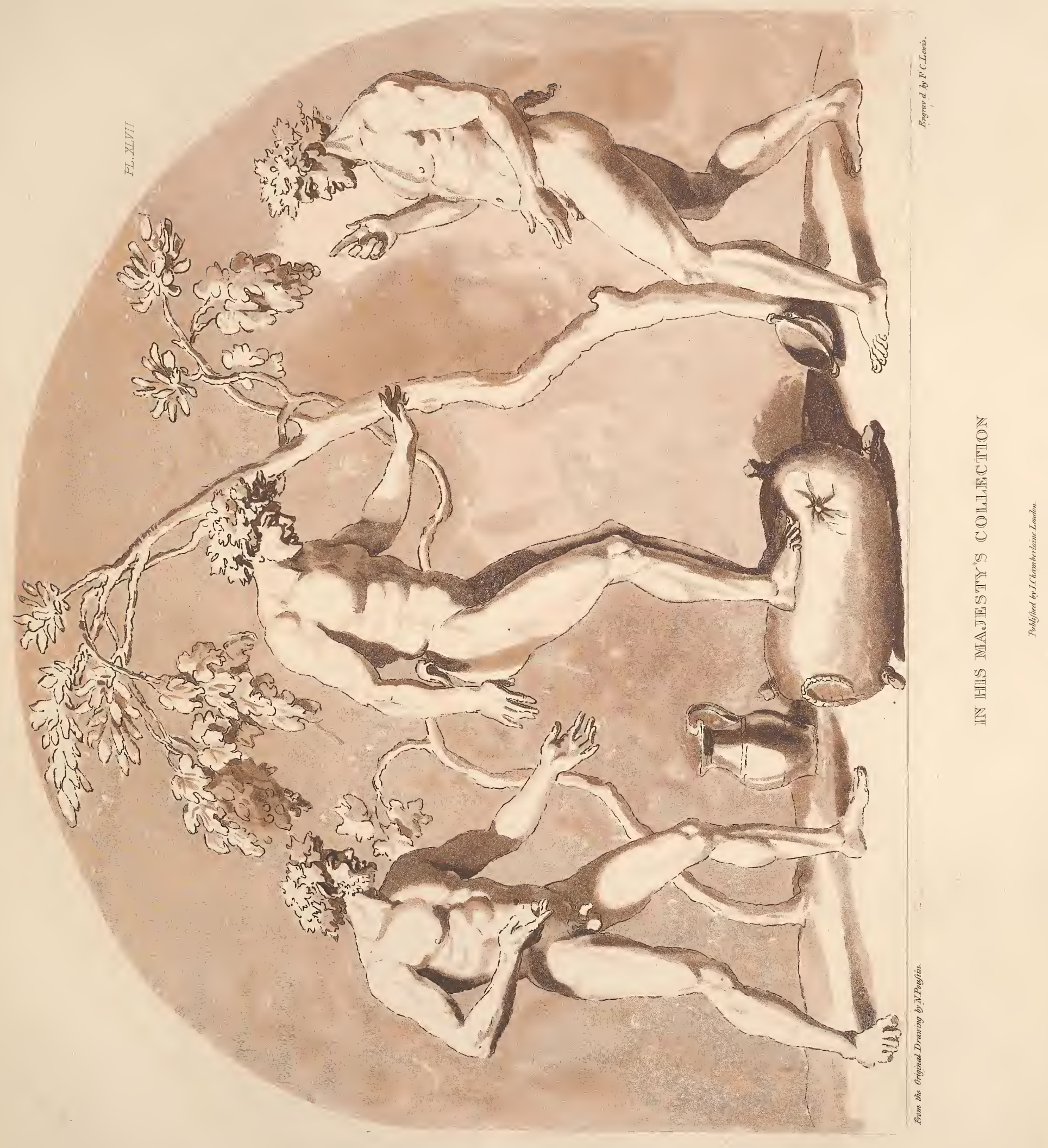






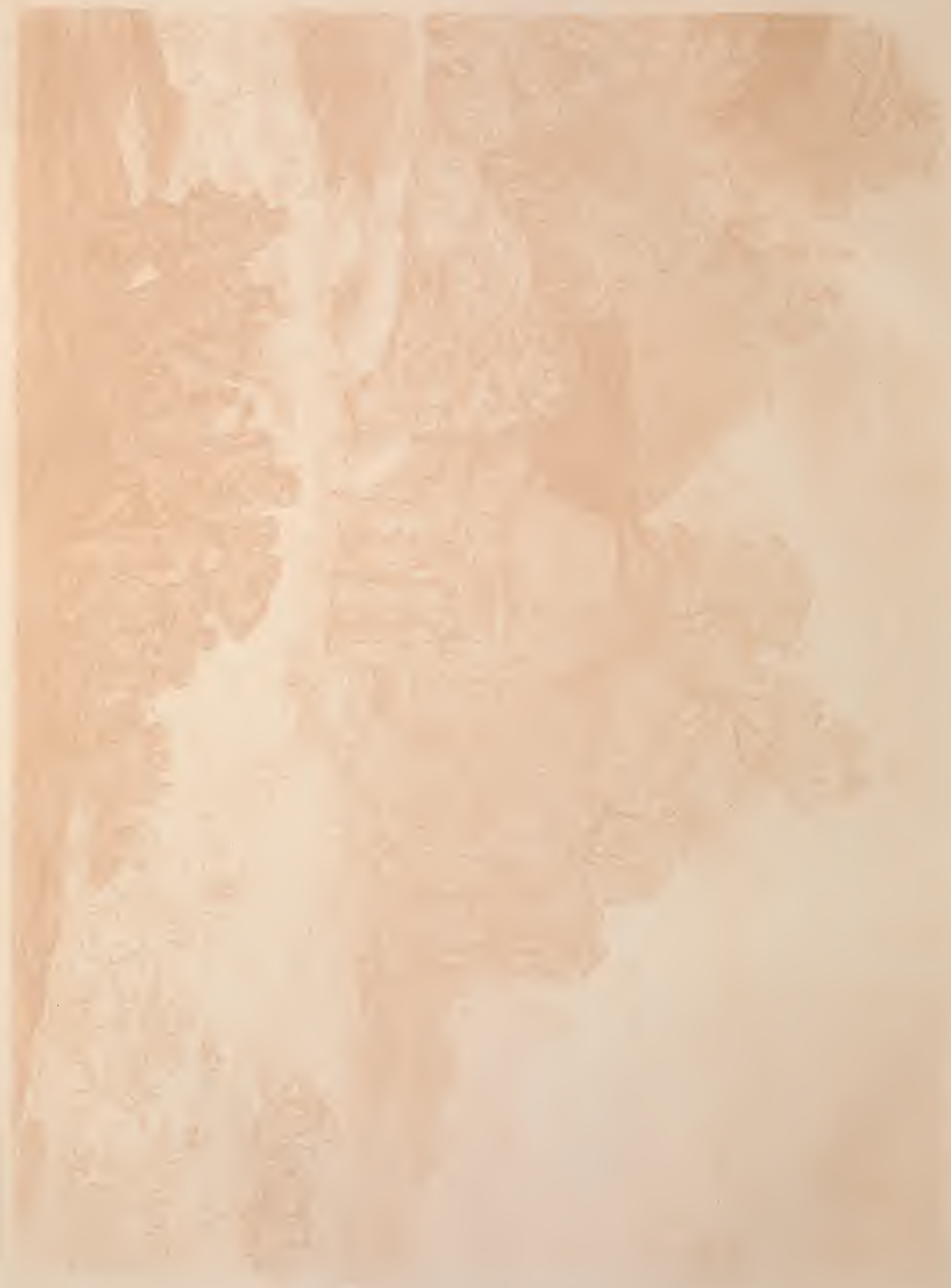




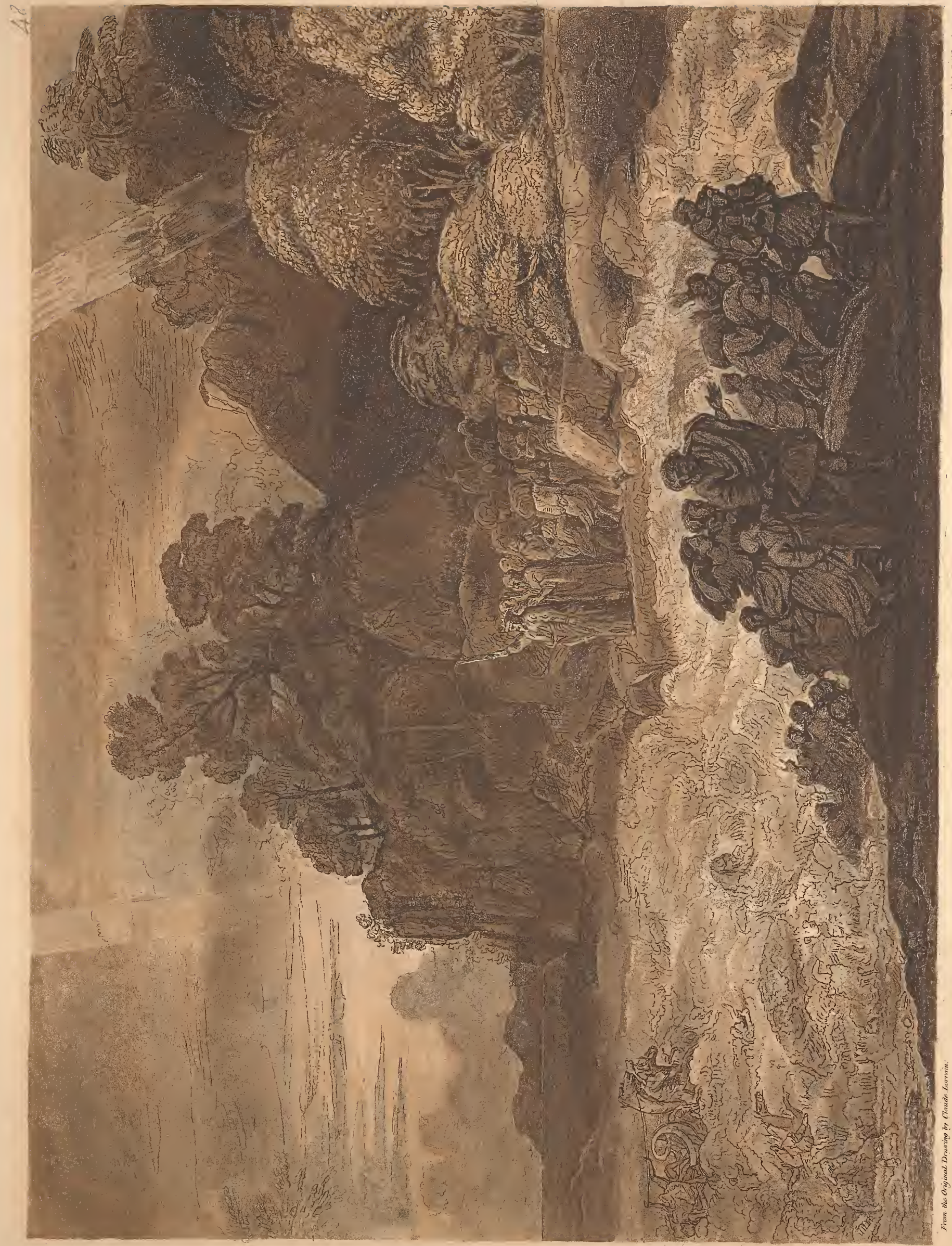






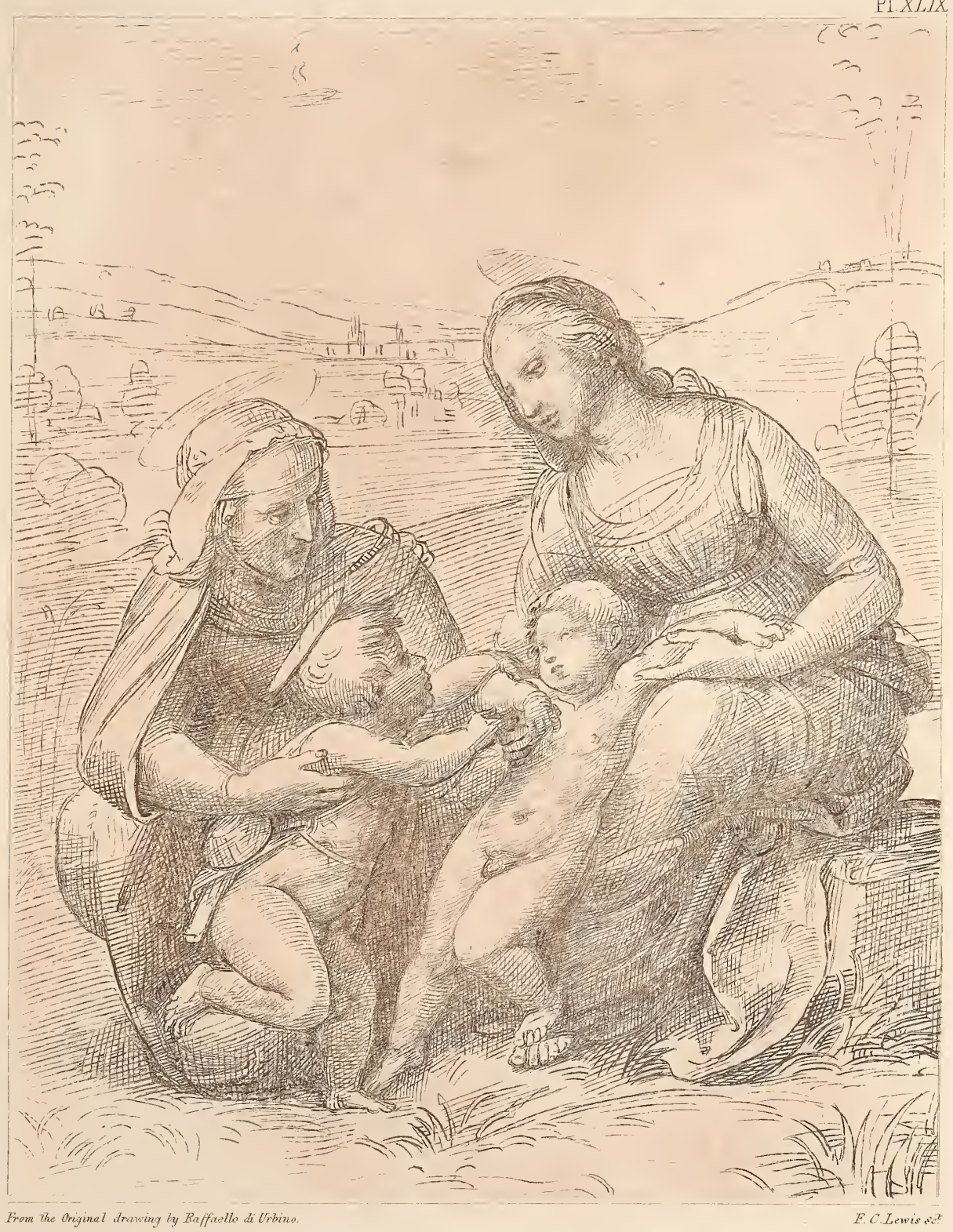

IN HUS MAJPSTY'S COHTECTION。 



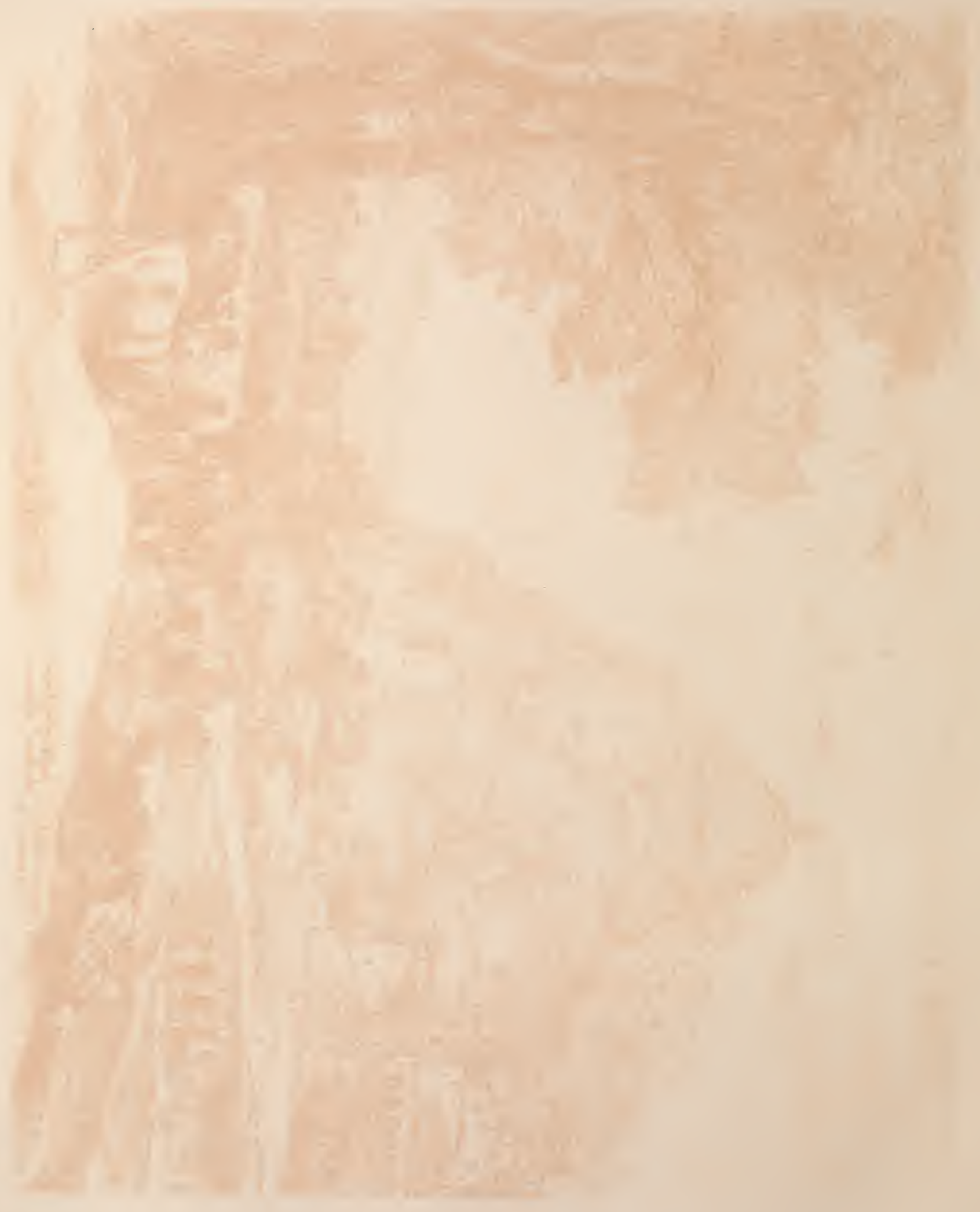




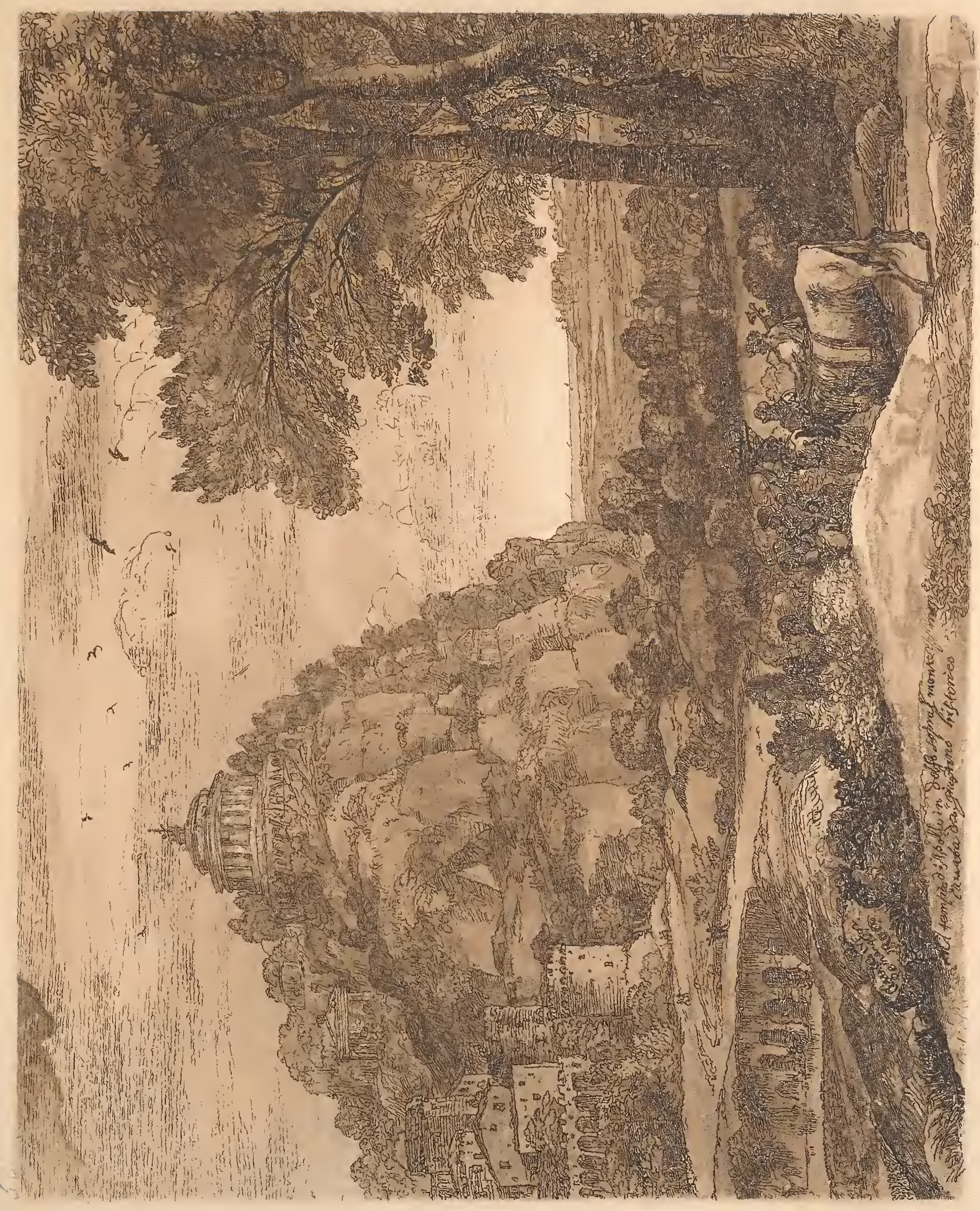






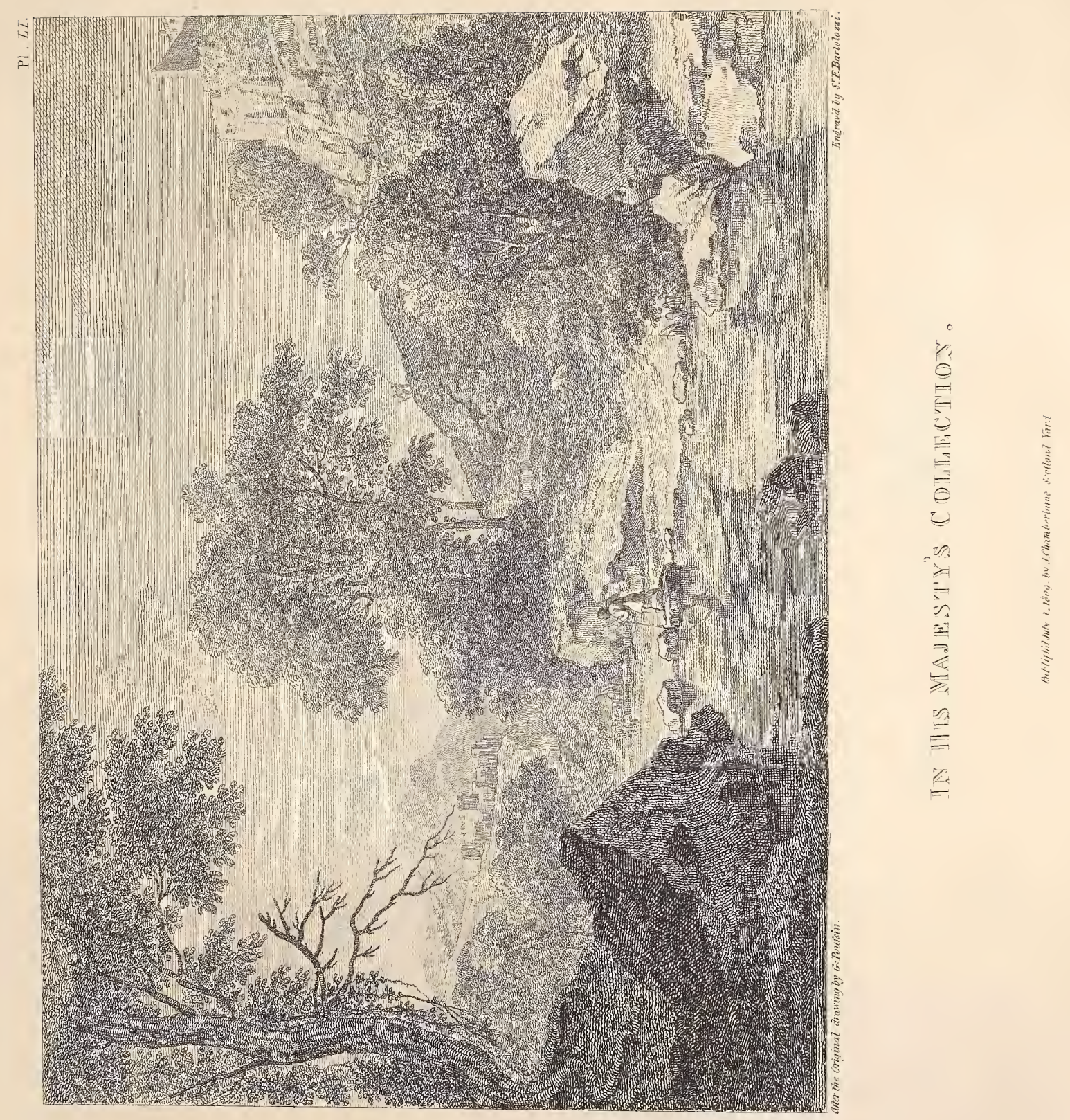






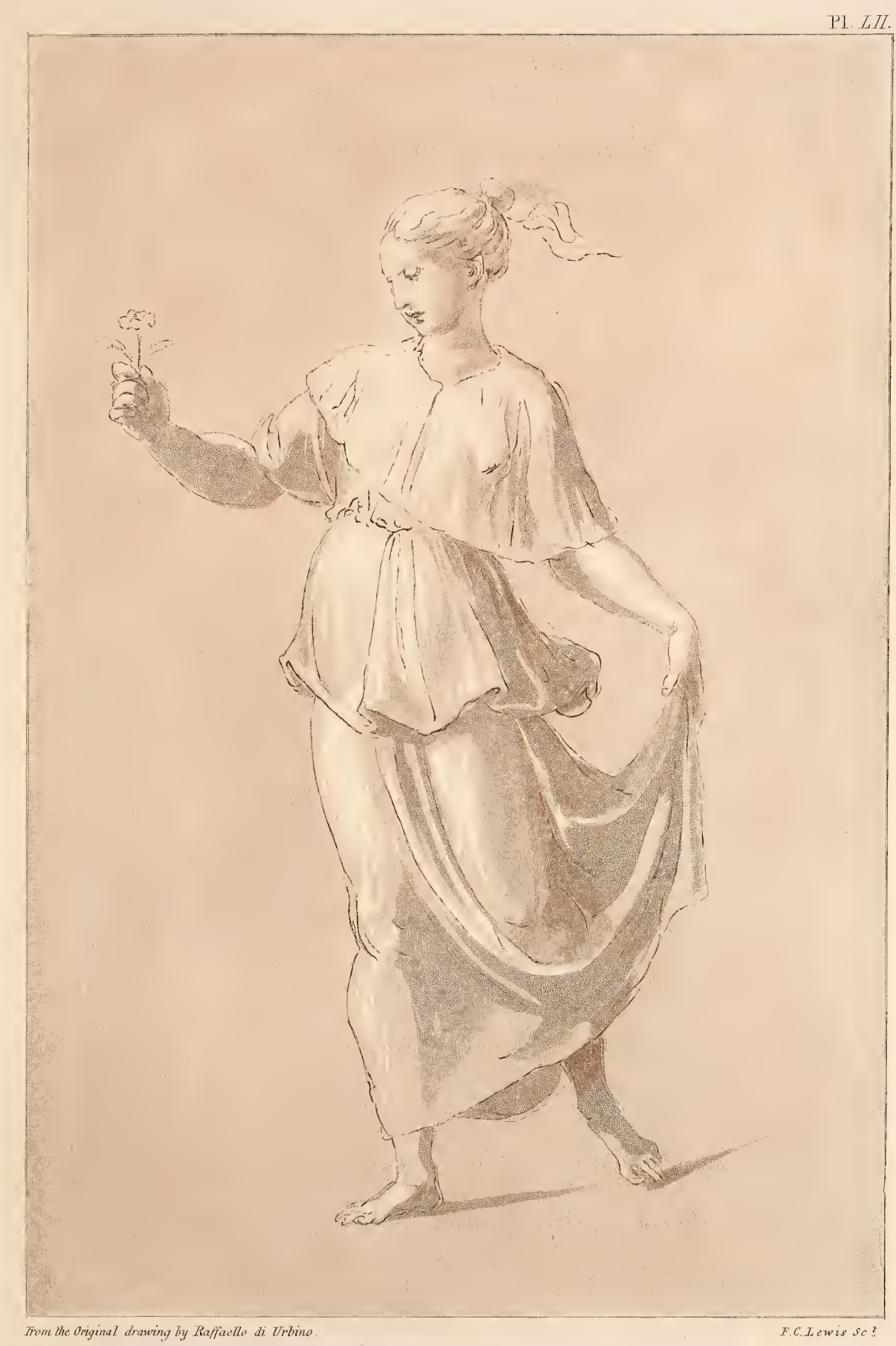

IN IITS YIAJUSTY'S COLIHECTION。 



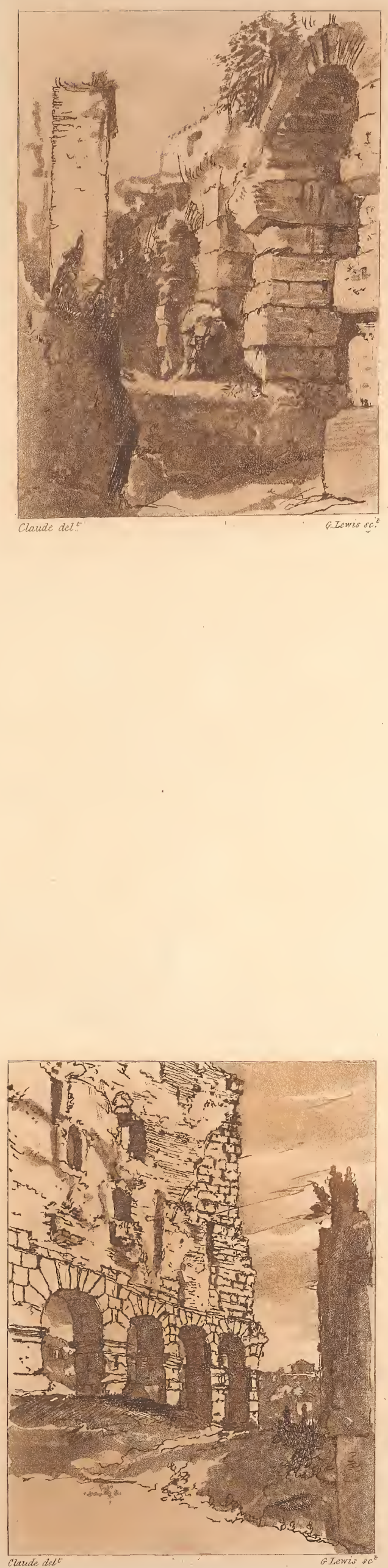



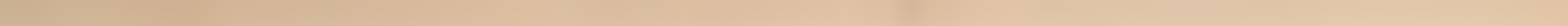





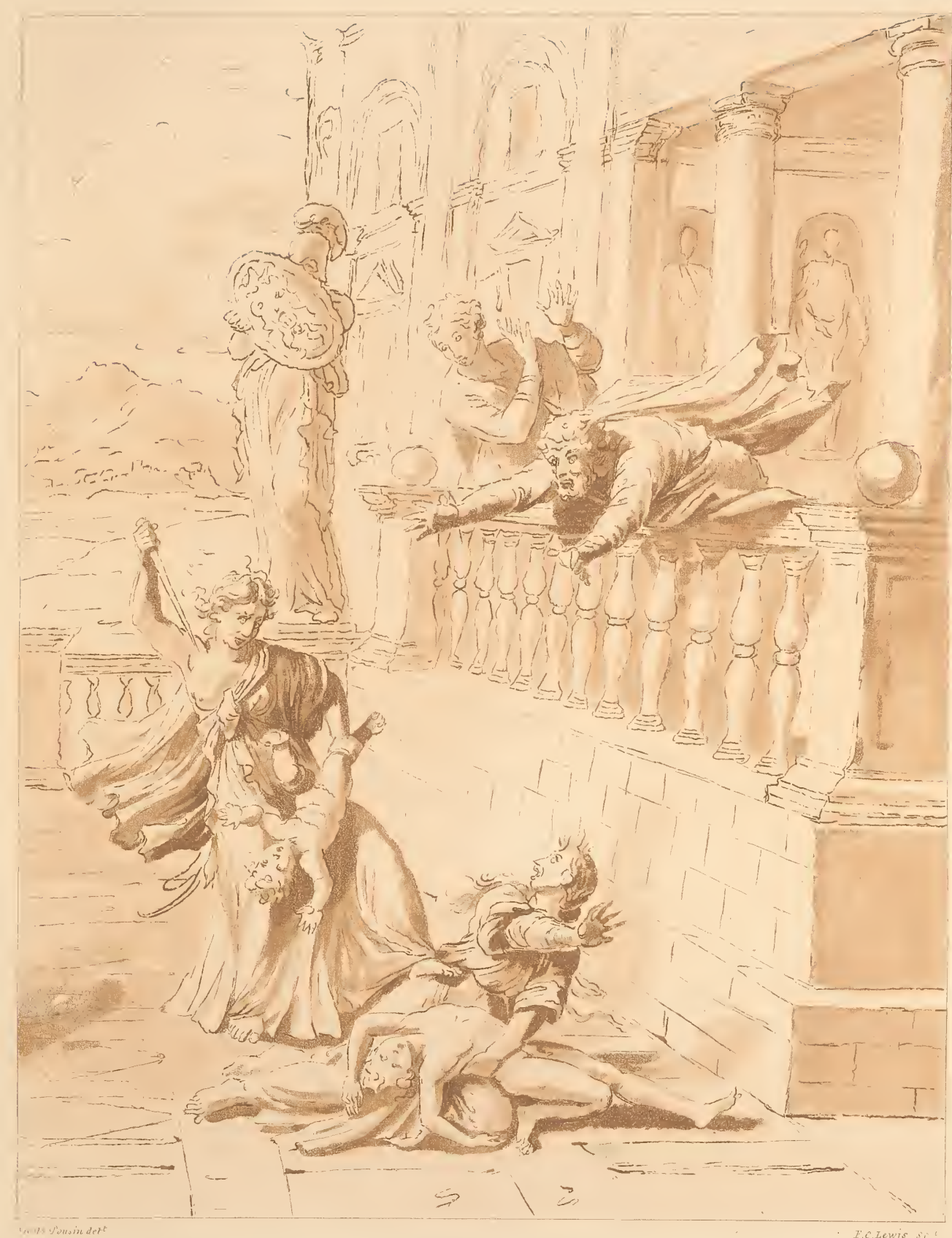






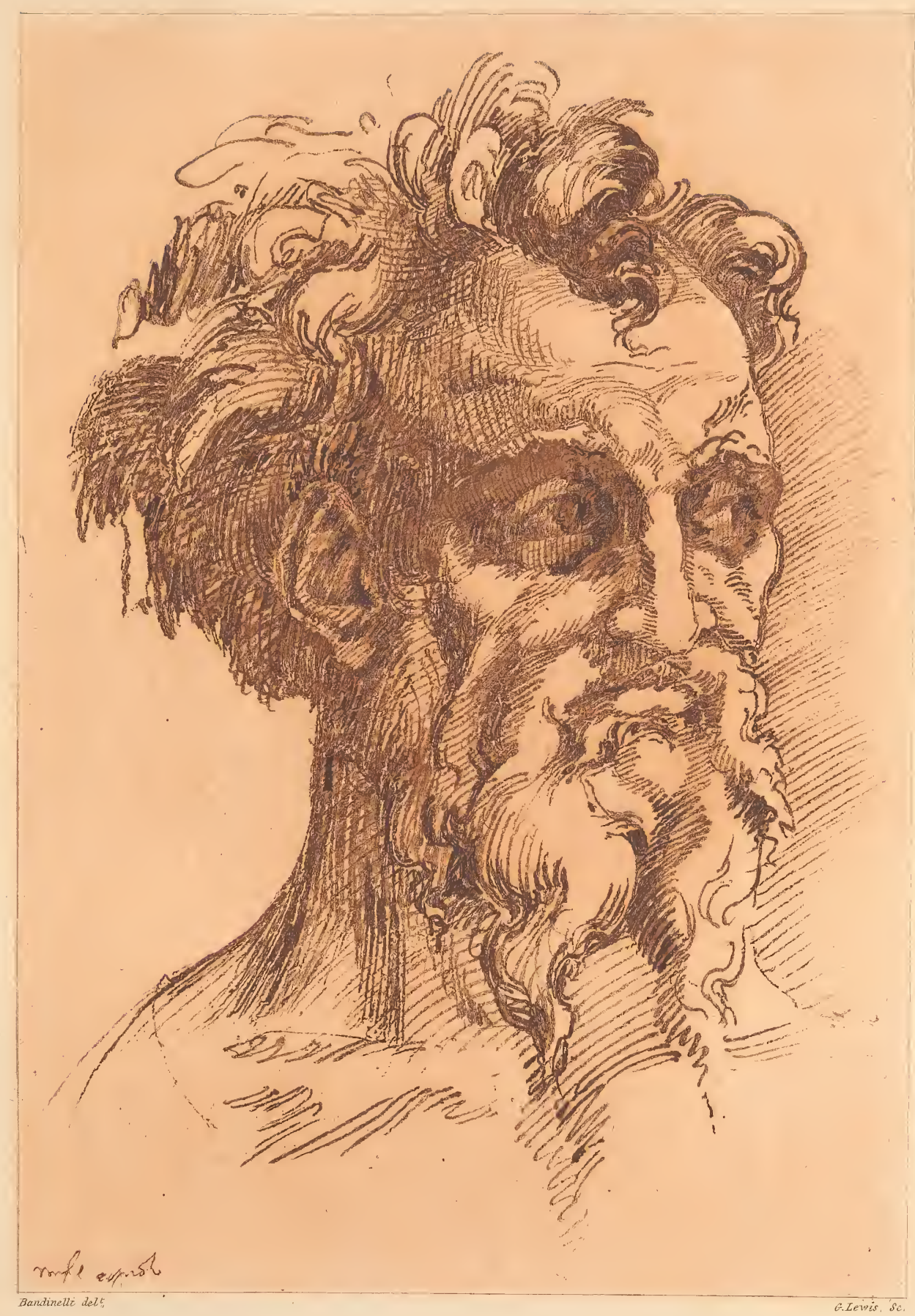






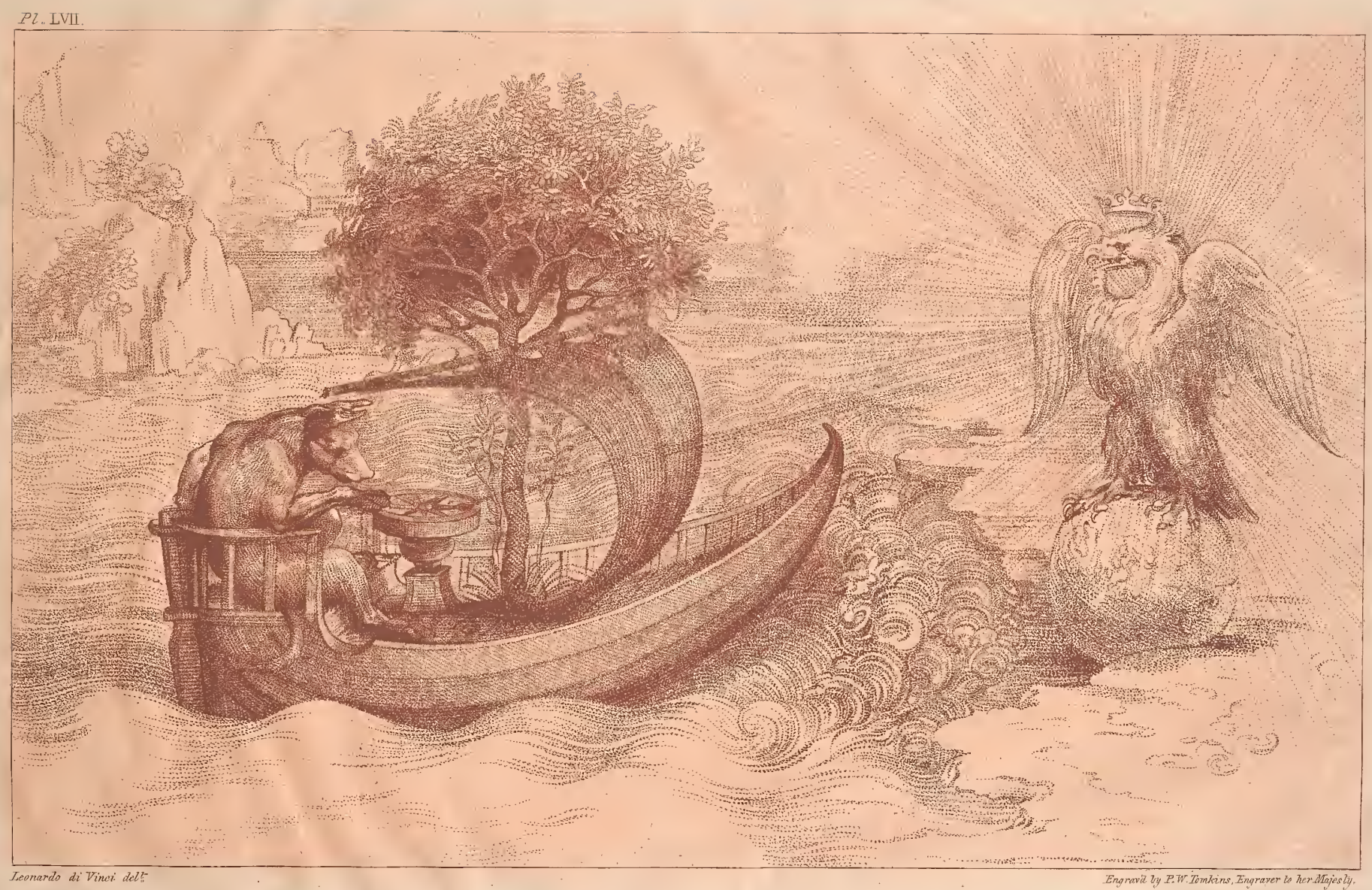





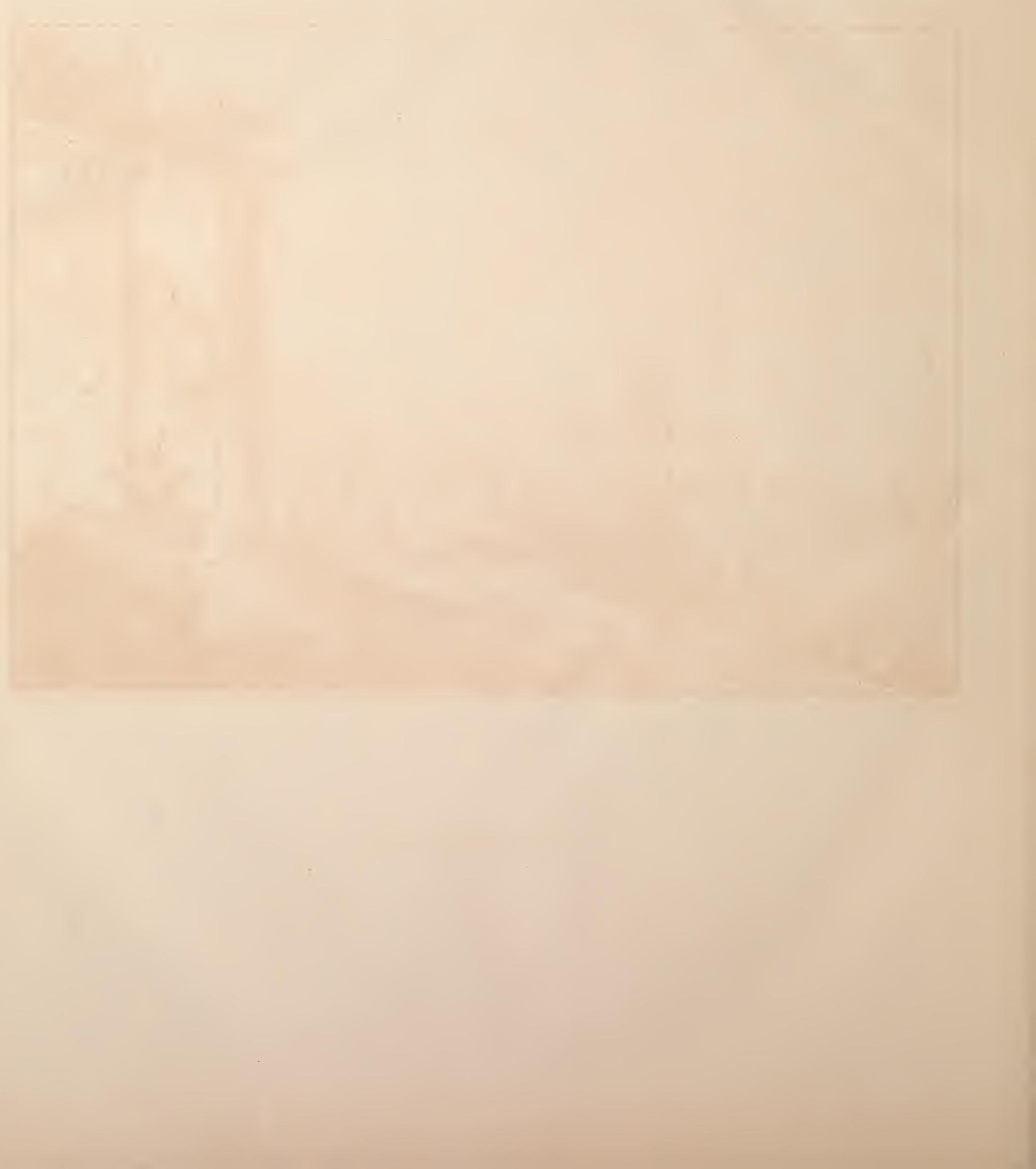




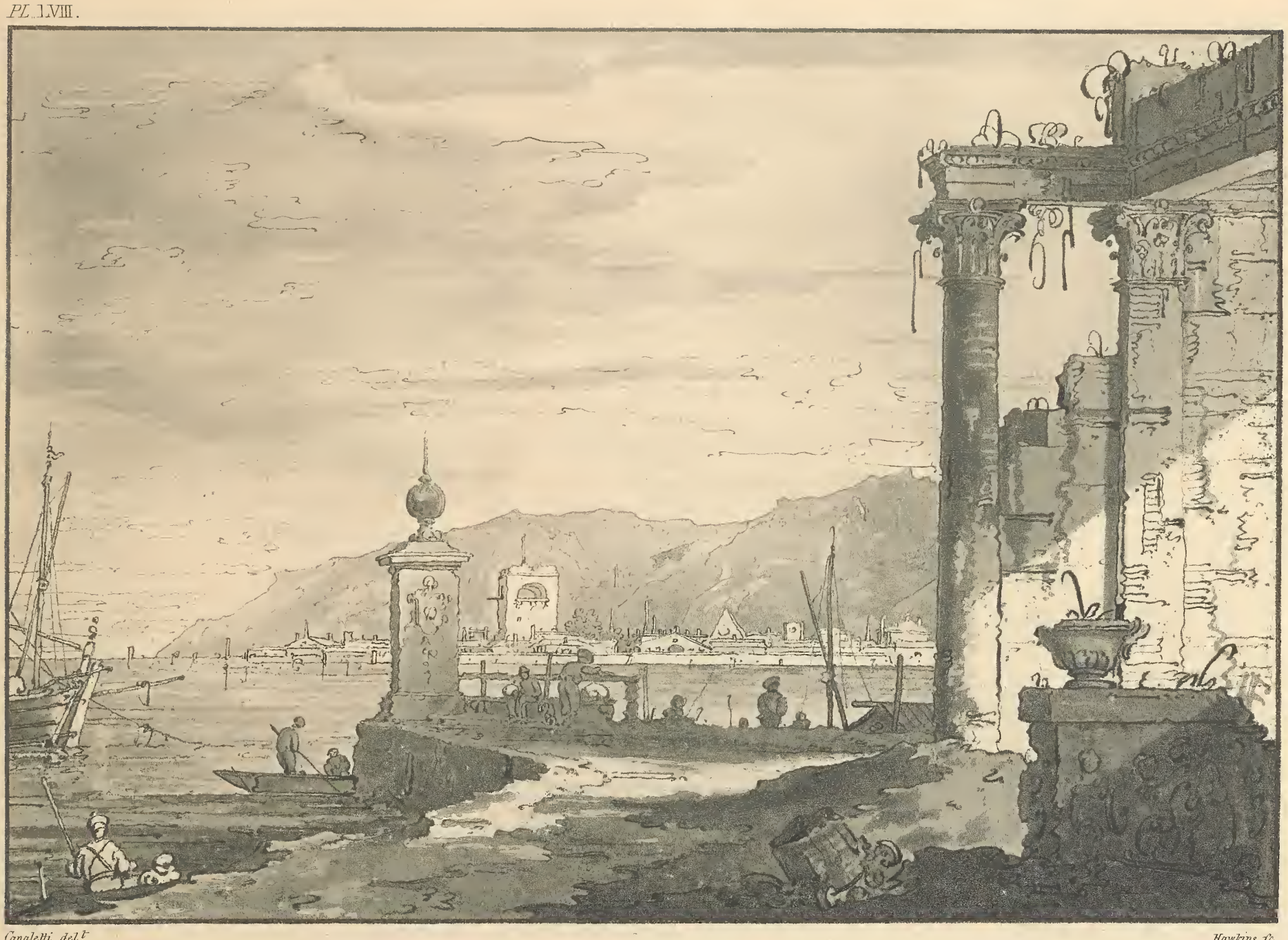





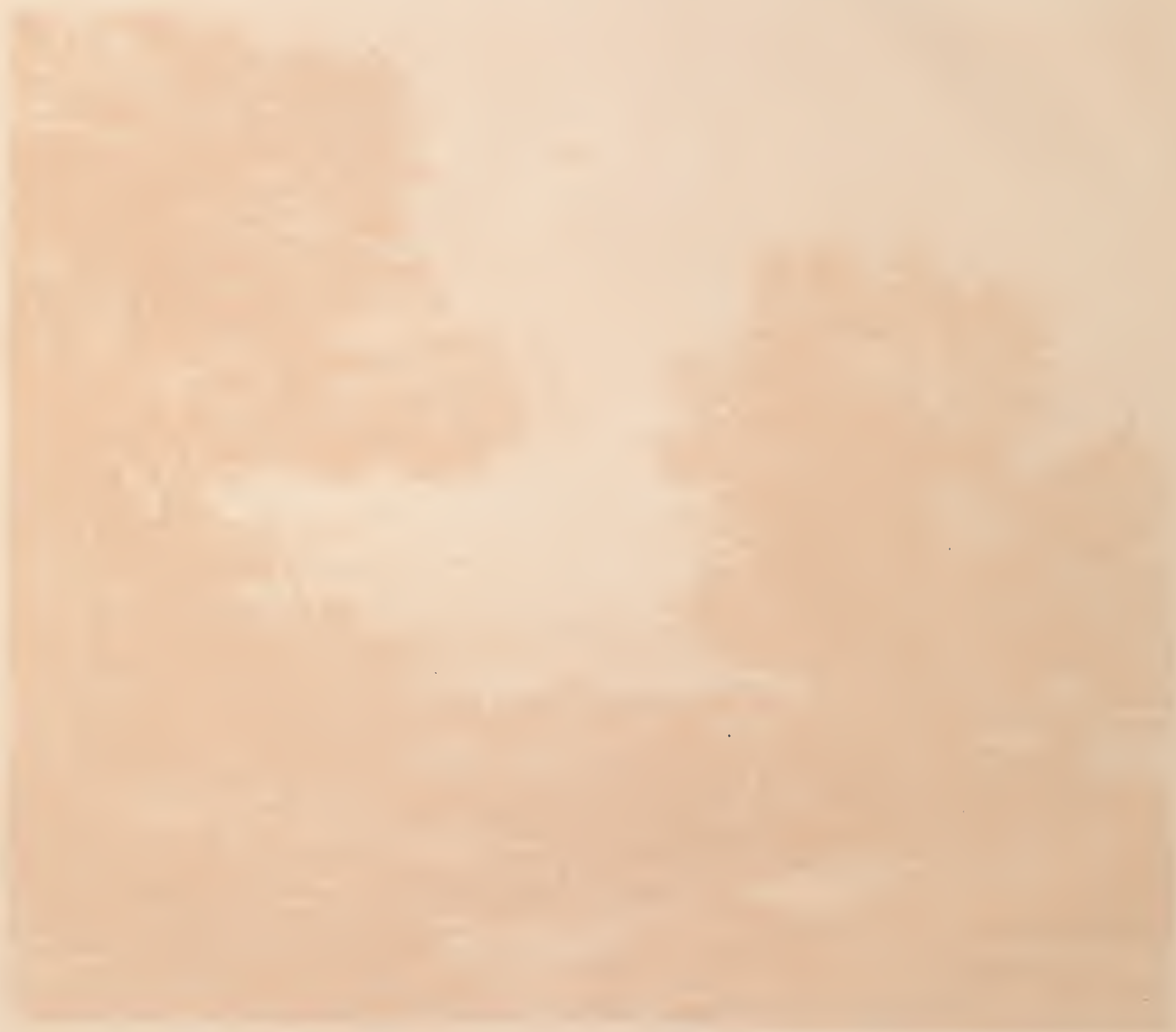




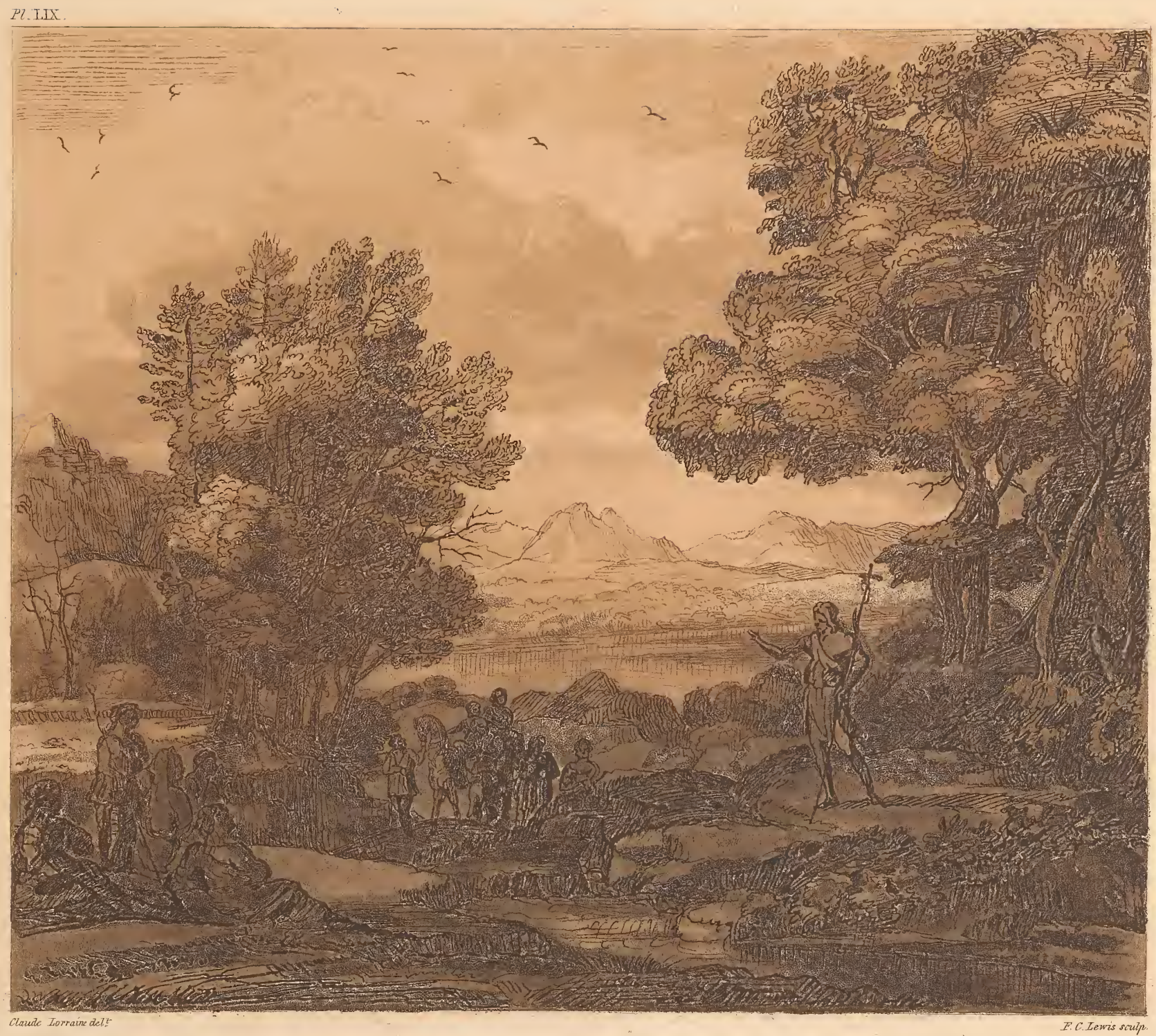

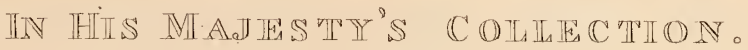





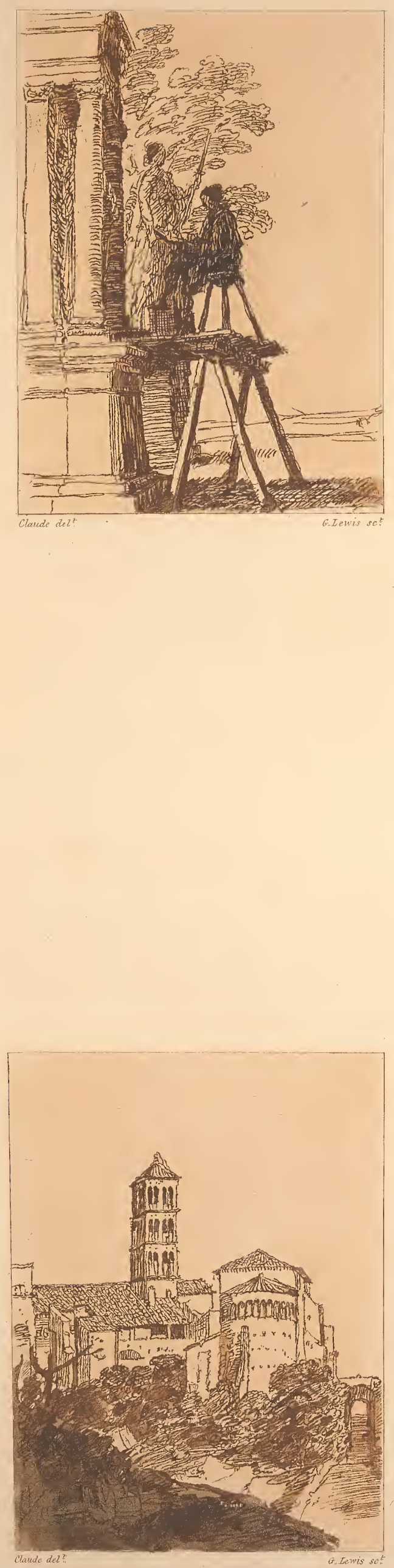




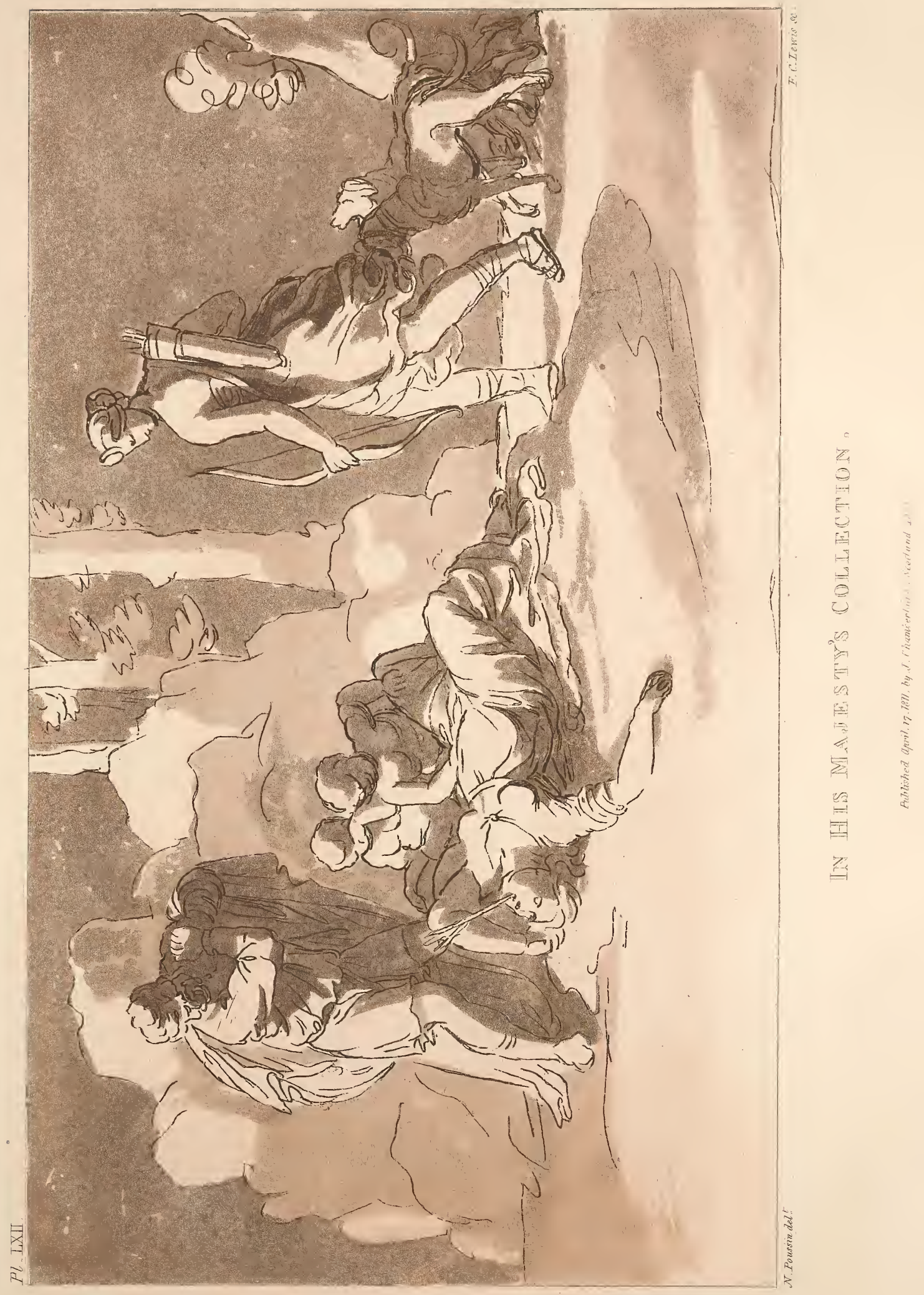







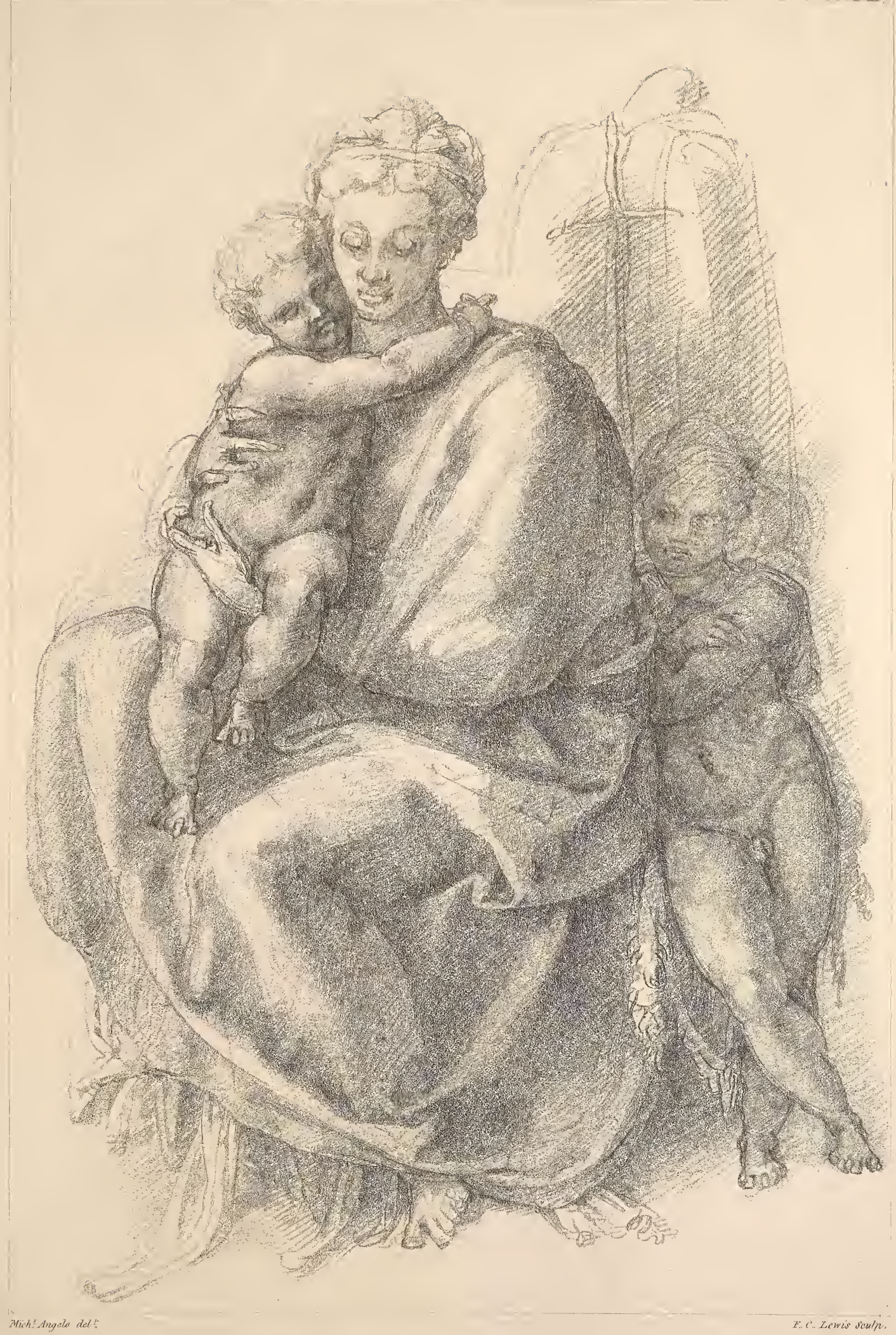

IN HIS MAJESTY'S CDLIGCTION。 




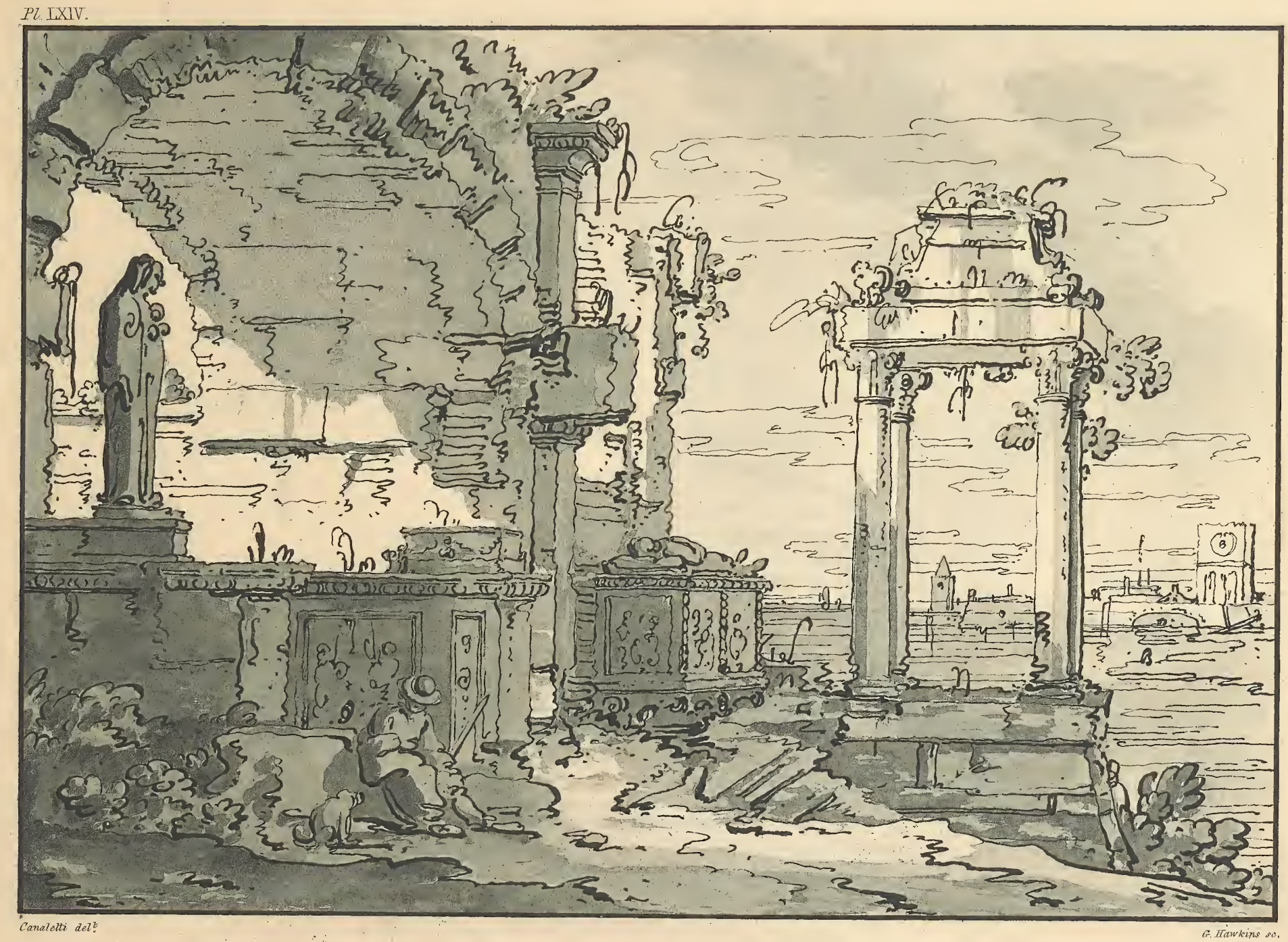

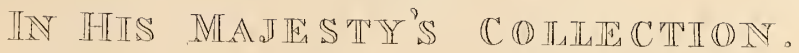






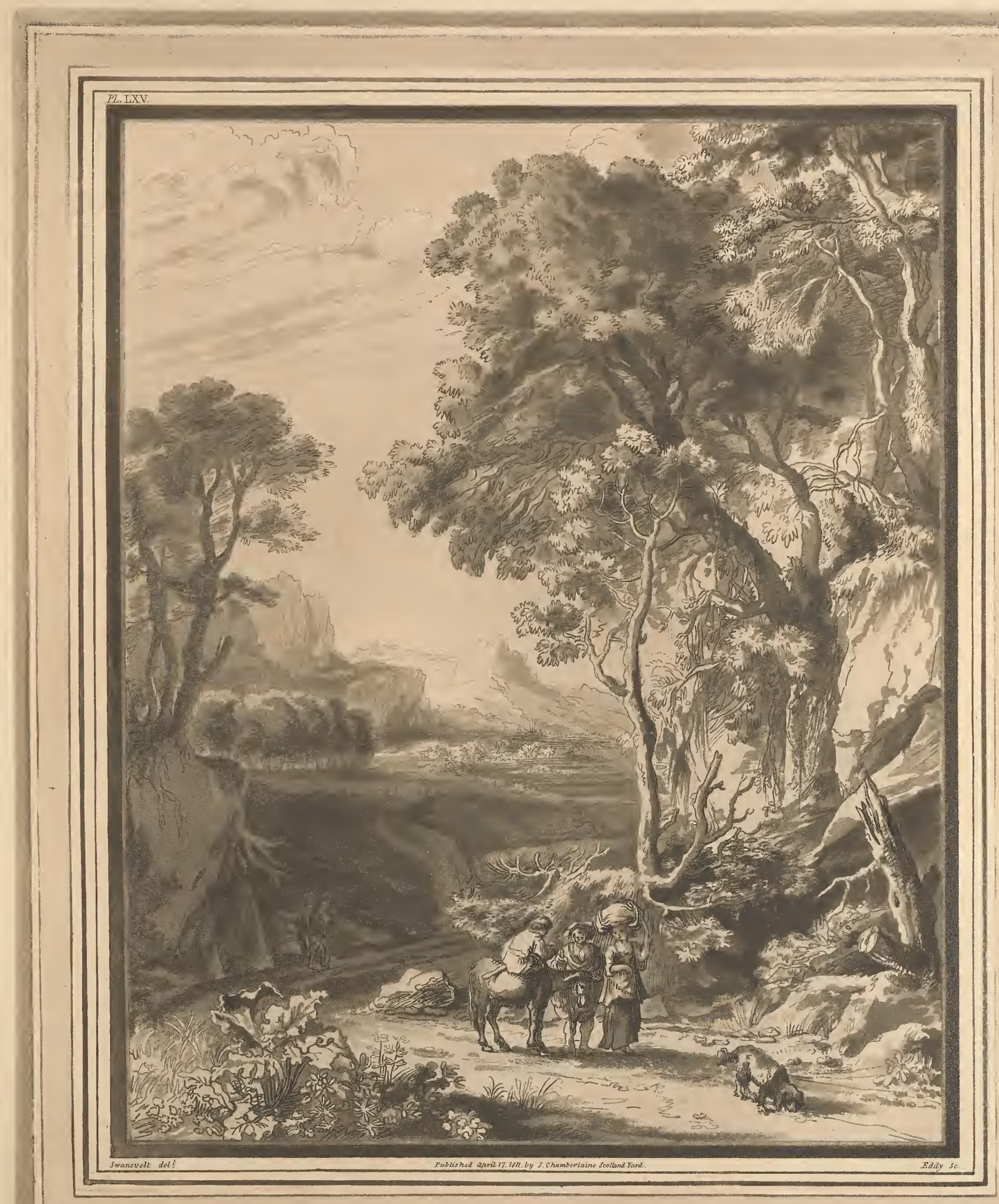






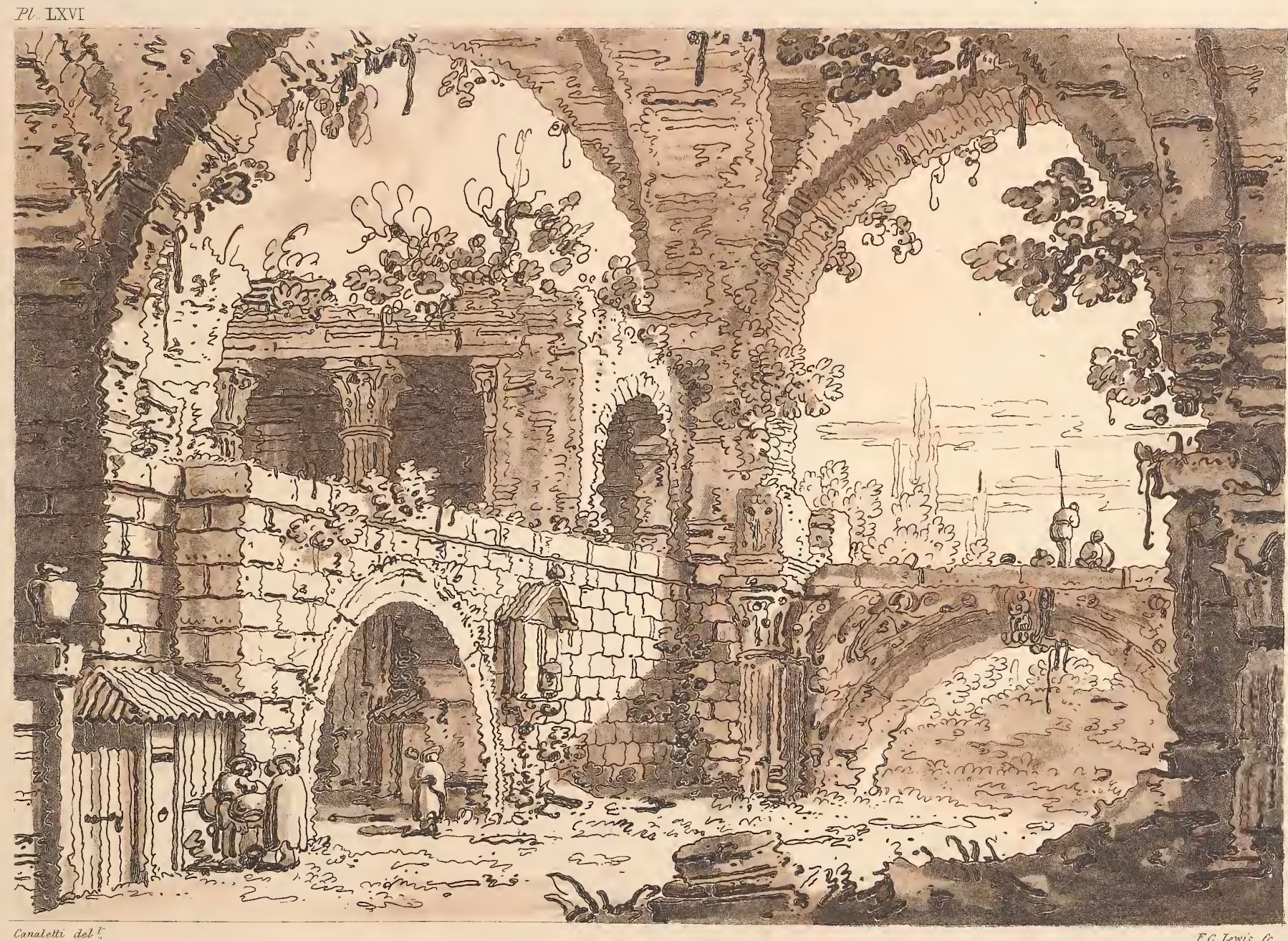

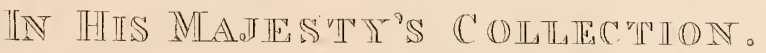



. 

te

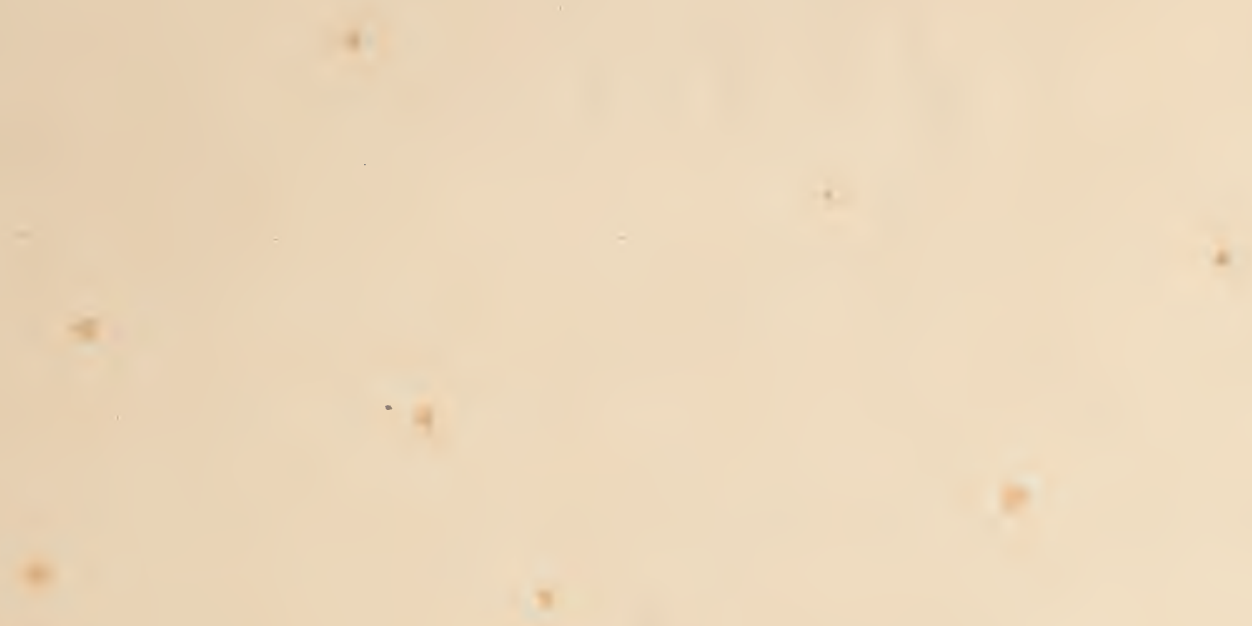

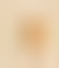




\section{(b) -210}

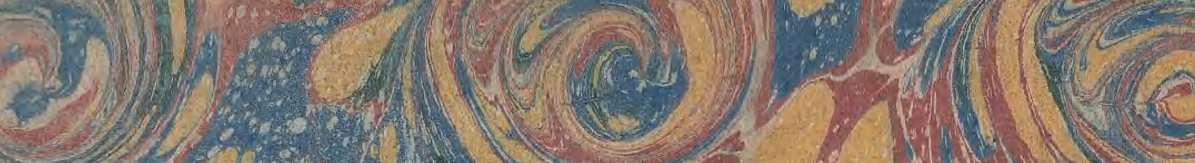

( -1.4

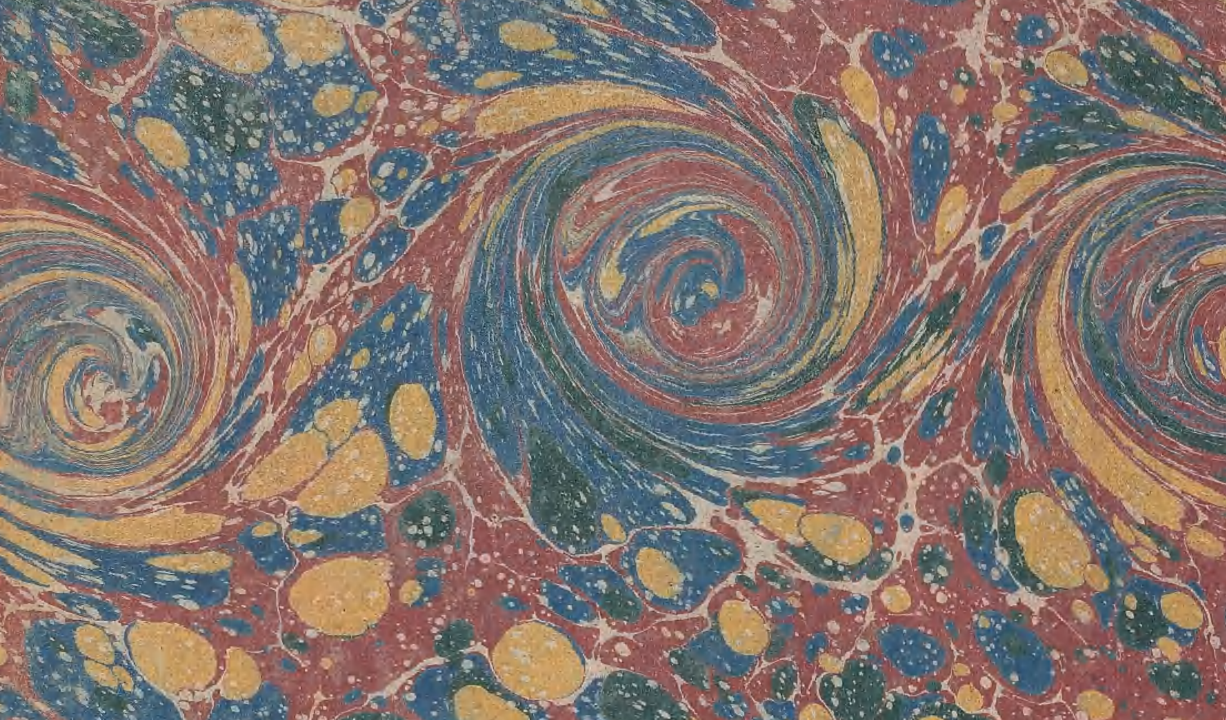

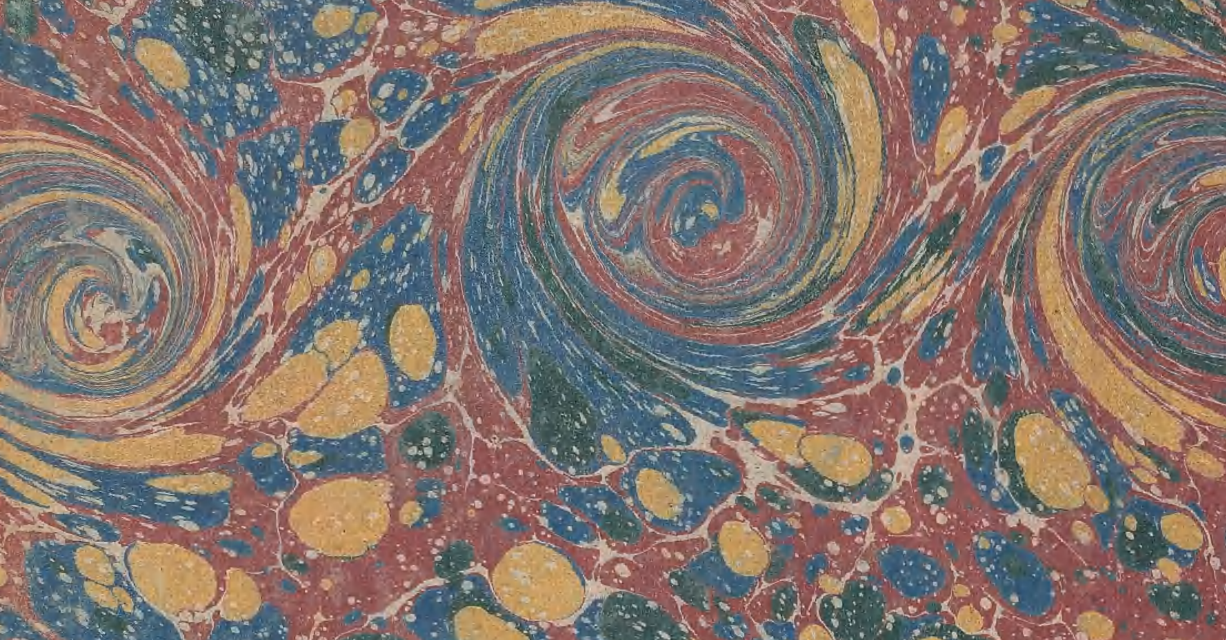

\section{r}

\section{-1(5)}

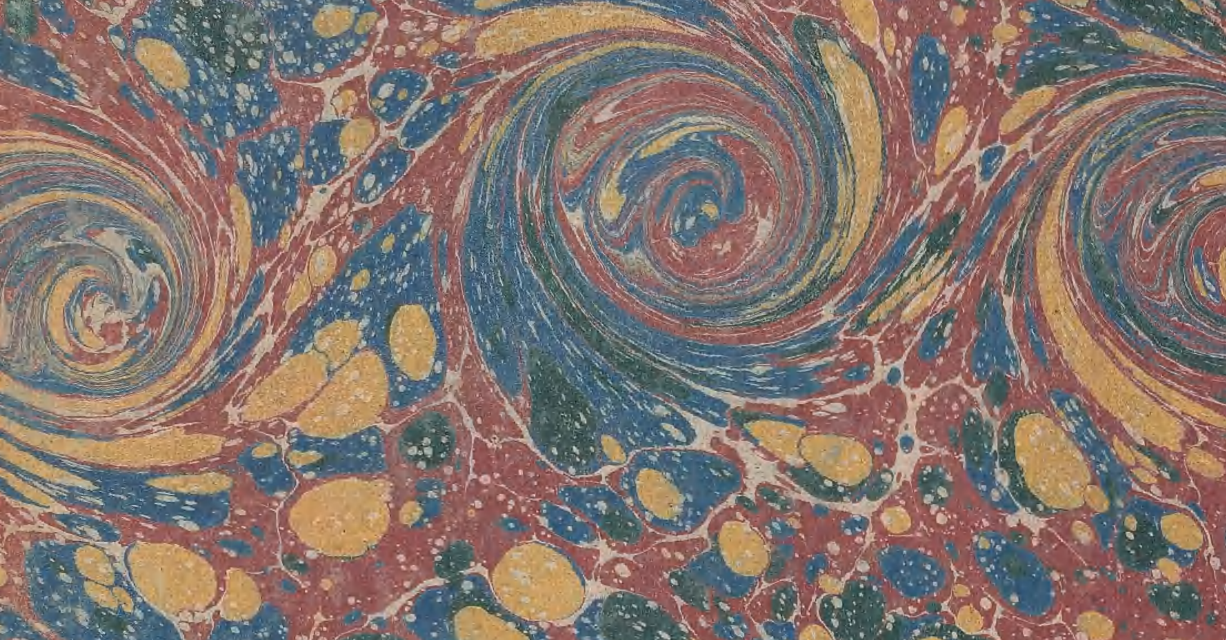

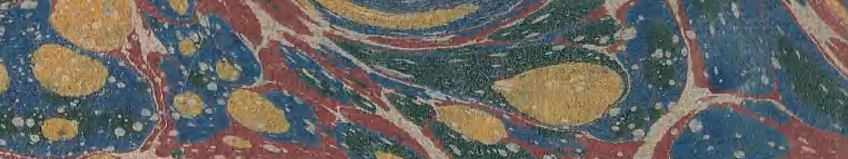

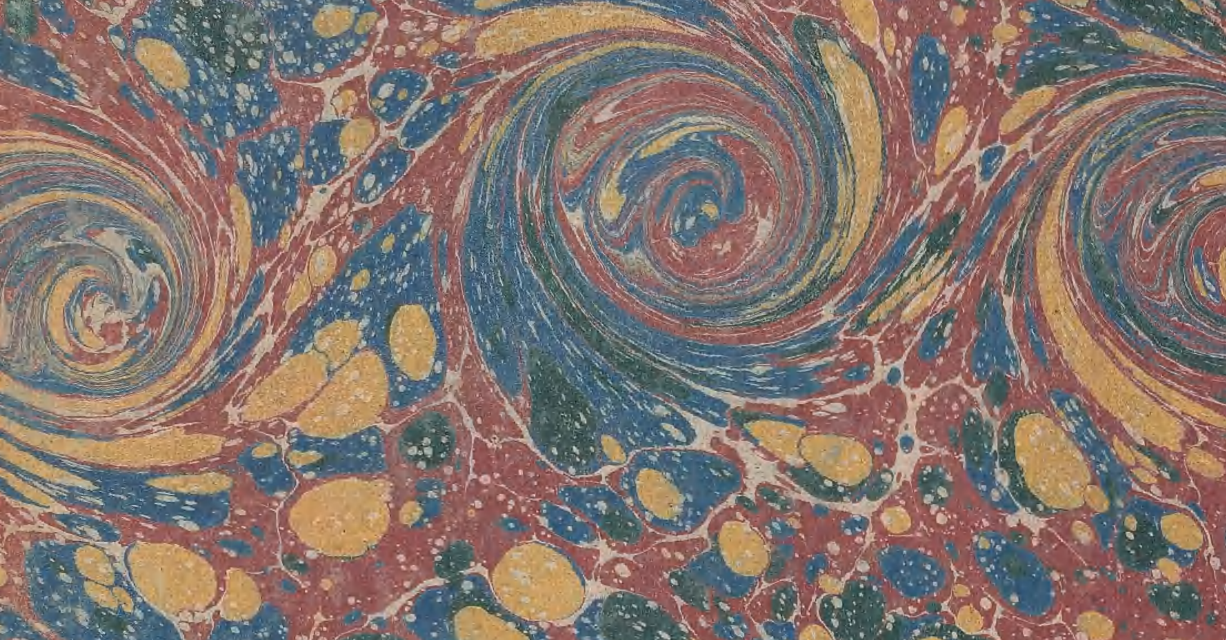

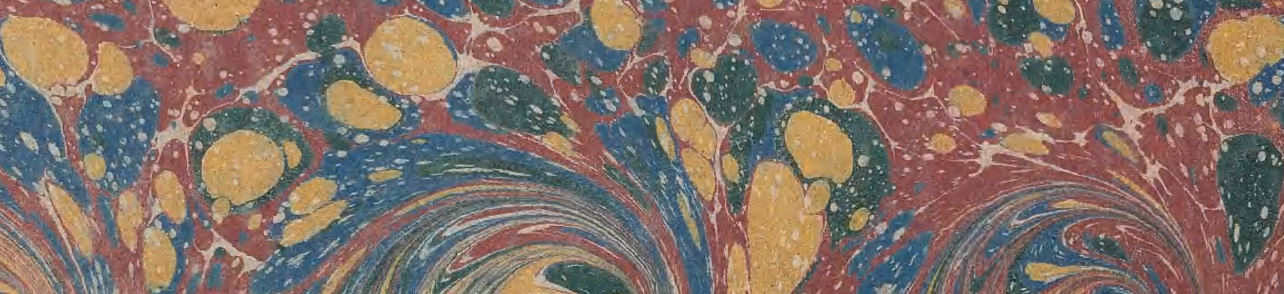

1.) (c)

1709020

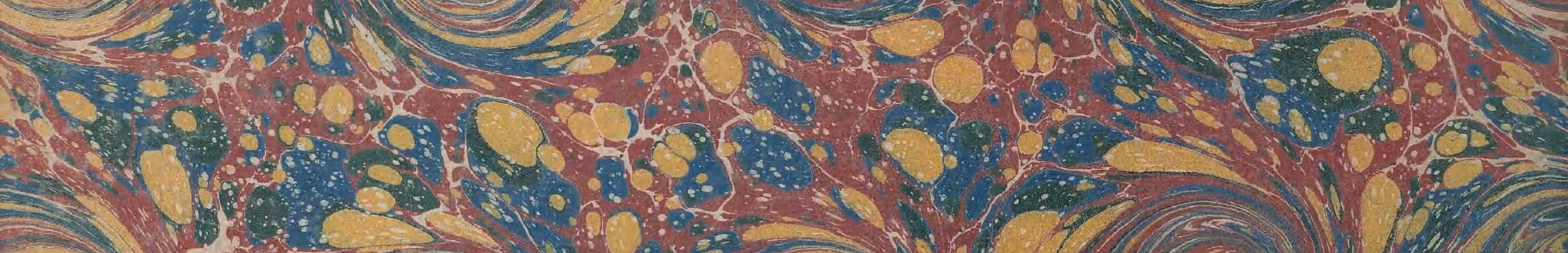

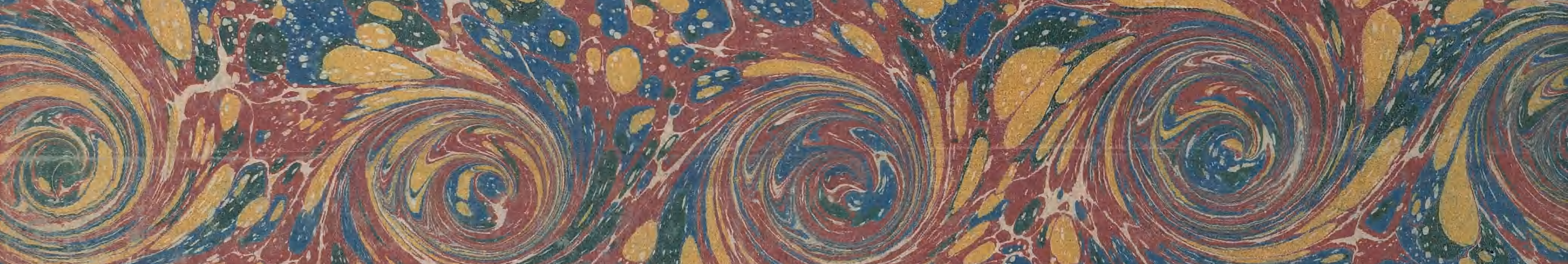

$32 \sqrt{5}$

61

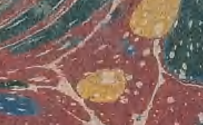

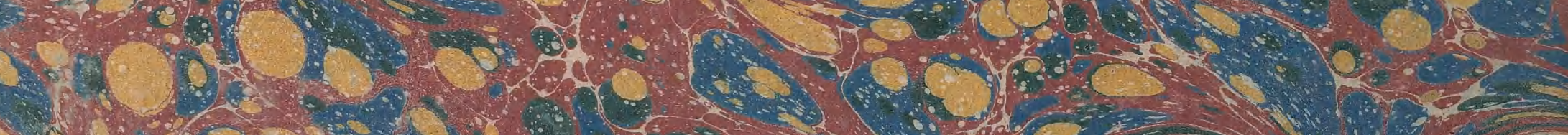

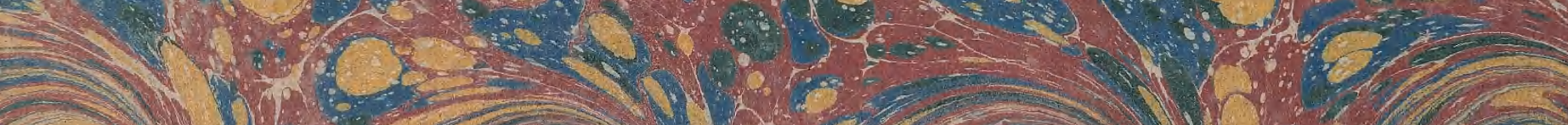

(c))

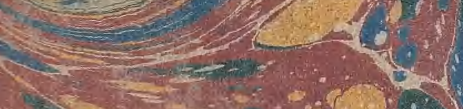

-

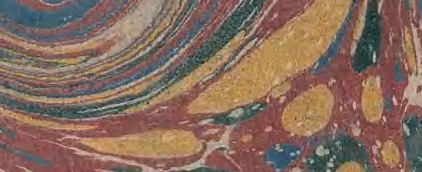

in
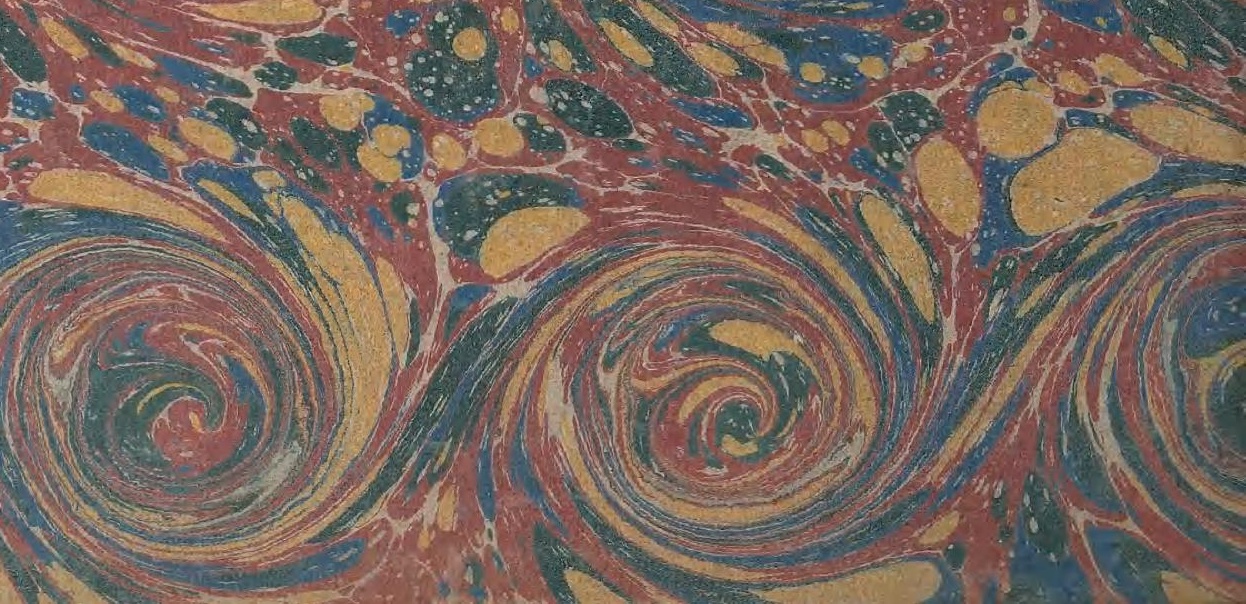

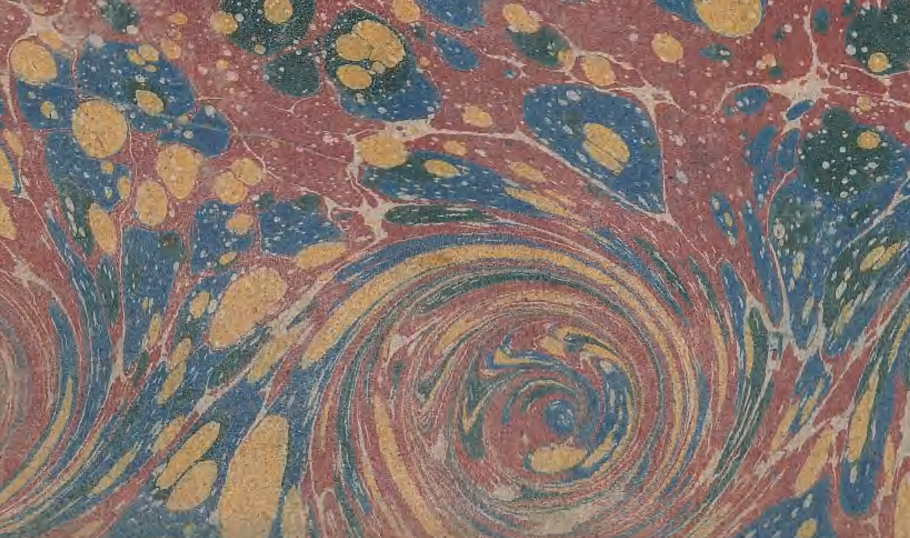




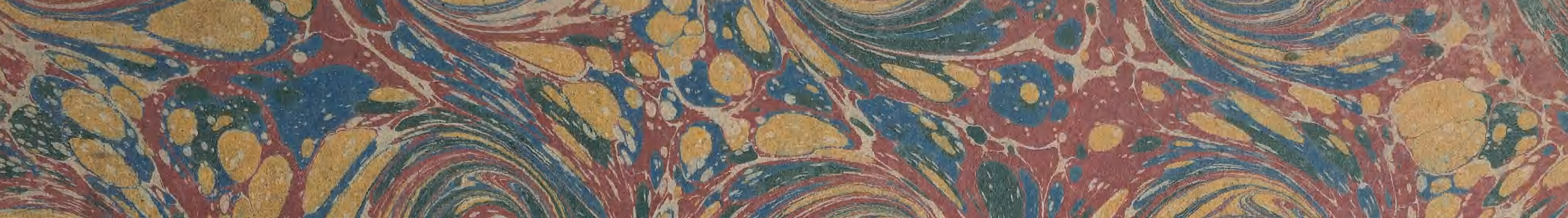
(2)

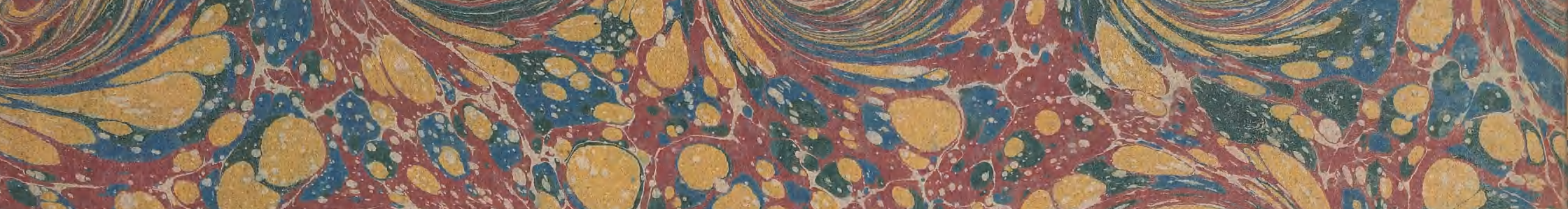

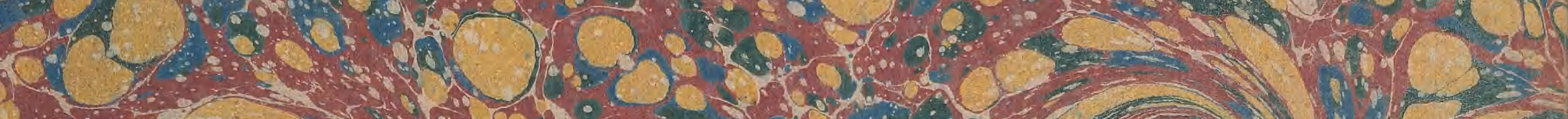

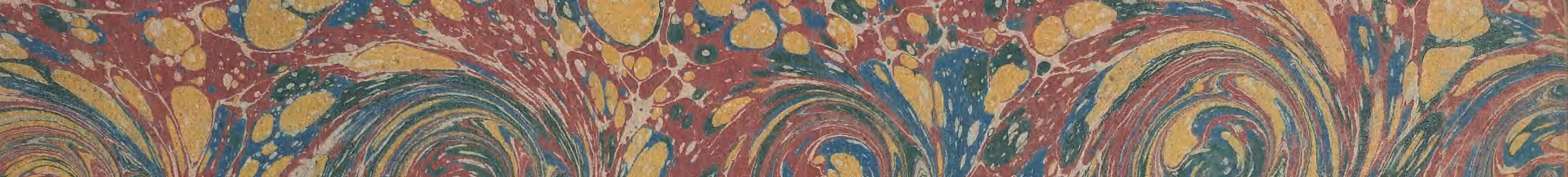
(cis)

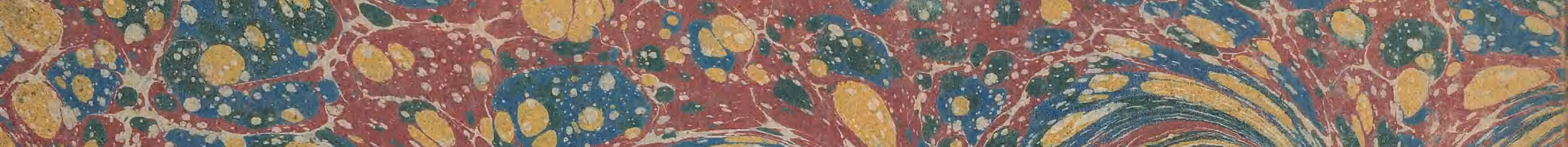

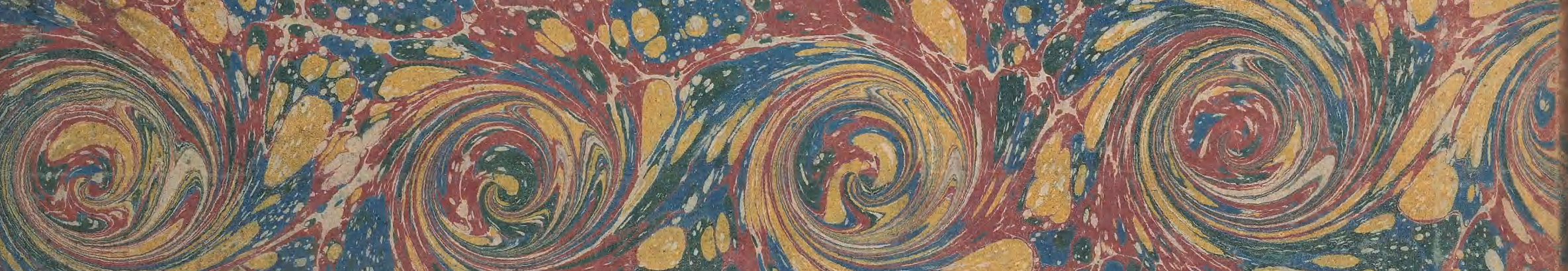

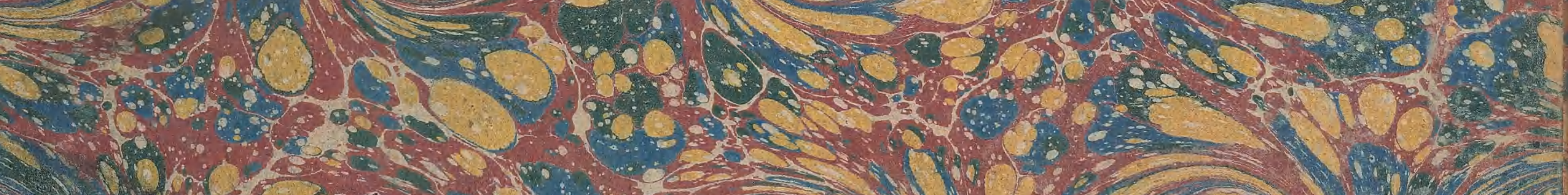

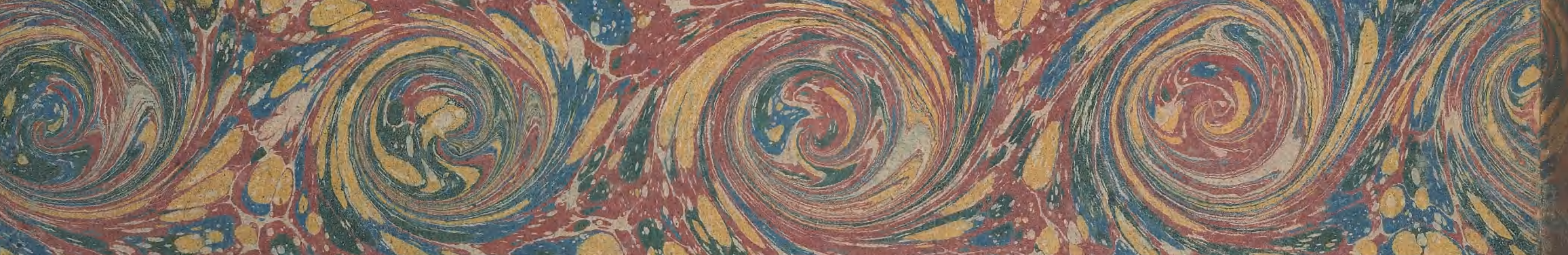

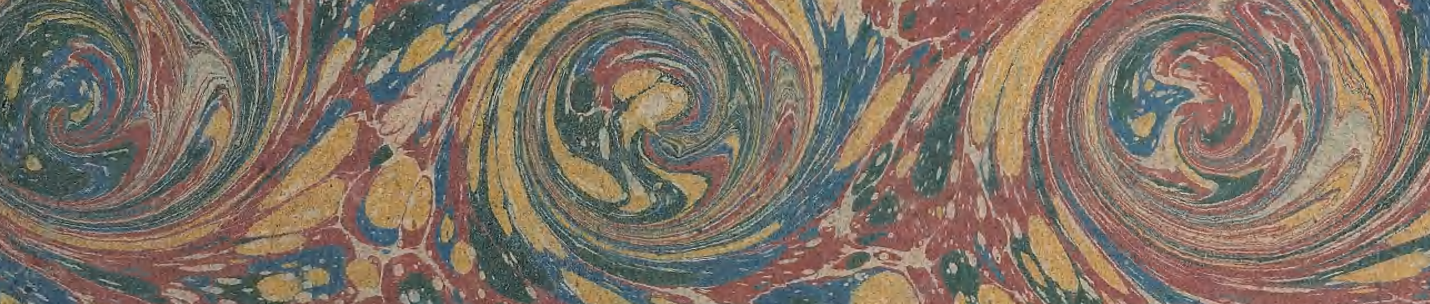

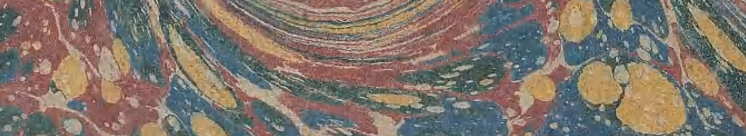

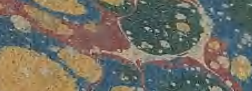

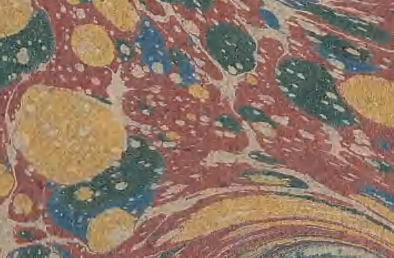

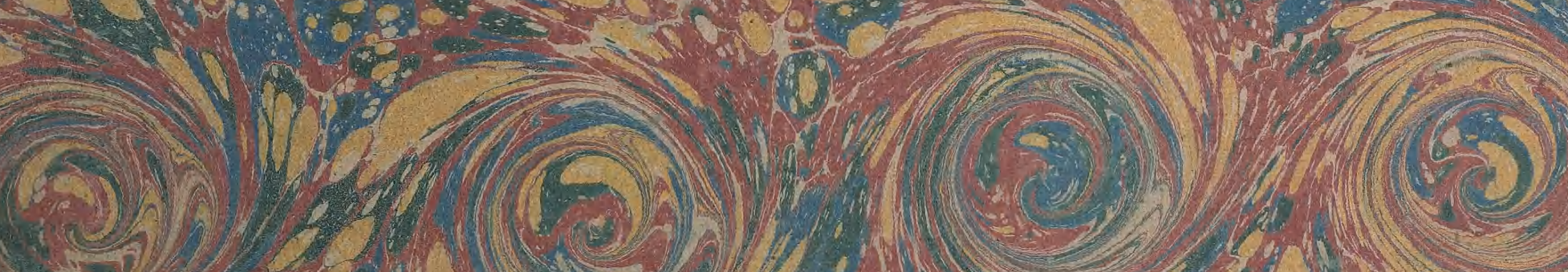




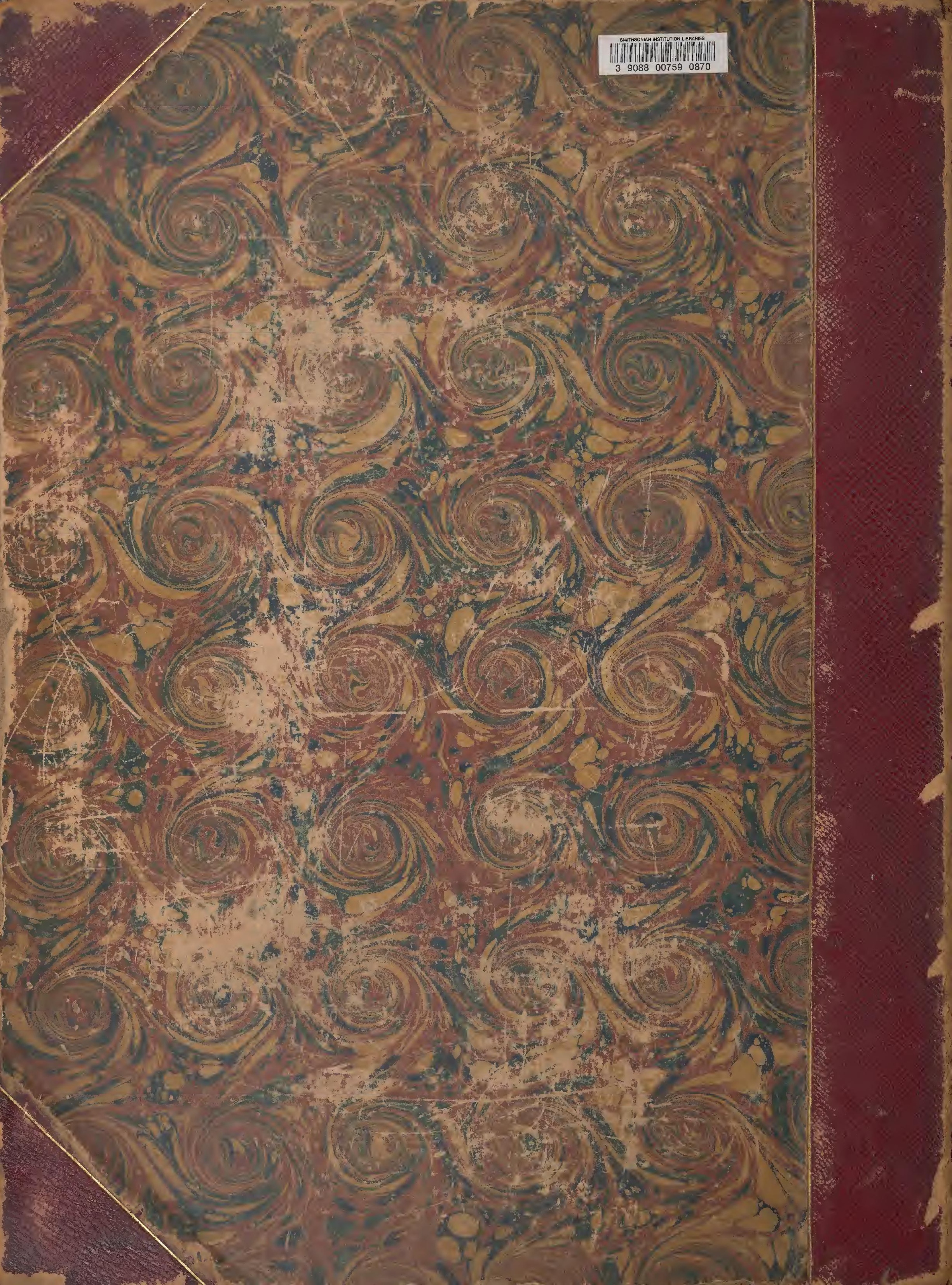

